\title{
Antioxidant Intake in Paediatric Oncology Patients
}

\author{
by \\ Sonja Slegtenhorst
}

Thesis presented in partial fulfilment of the requirements for the degree Master of Nutrition at the University of Stellenbosch

\author{
Supervisor: Mrs Janicke Visser \\ Co-supervisor: Dr Rosan Meyer \\ Faculty of Health Sciences \\ Department of Interdisciplinary Health Sciences \\ Division of Human Nutrition
}




\section{DECLARATION:}

By submitting this thesis electronically, I declare that the entirety of the work contained therein is my own, original work, that I am the sole author thereof (save to the extend explicitly otherwise stated) that reproduction and publication thereof by Stellenbosch university will not infringe any third party rights and that I have not previously in its entirety or in part submitted it for obtaining any qualifications. 


\section{ABSTRACT}

Background: The role of antioxidants and adequate nutrition in the prevention and course of cancer treatment is globally recognised in nullifying the effects of free radicals and increasing the nutritional status of children during treatment.

Objective: To investigate whether children with cancer meet their Dietary Reference Values and Safe Intakes for antioxidants, energy and protein.

Design: Single centre prospective study.

Setting: Children were recruited from the East of England Primary Treatment Centre using convenience sampling over 8 months. Forty-two children and adolescents diagnosed with a Solid tumour, Lymphoma or Leukaemia were eligible for data analysis ( $n=20$ male; $n=22$ female).

Method: Data was collected with an Estimated Food Record (EFR) in the $1^{\text {st }}$ (EFR1) and $3^{\text {rd }}$ month (EFR2) post-diagnosis. In the week following EFR completion, parents and/or children were contacted to complete four non-consecutive days of $24-\mathrm{hr}$ food recalls. Data was categorised into diet alone, diet + food supplement (FS), tube feeding (tube) or diet + multi-vitamin-mineral supplementation (VMS). Malnutrition was determined by weight-for-age z-scores. Nutrient intake was compared to the Recommended Nutrient Intake (RNI), the Estimated Average Requirements (EAR) and the Lower Recommended Nutrient Intake (LRNI).

Result: The sample consisted of $33 \%(n=14)$ diagnosed with Leukaemia, $24 \%(n=10)$ with Lymphoma and $43 \%(n=18)$ with Solid tumours. Sixty seven percent $(n=28)$ underwent chemotherapy and $33 \%(n=14)$ a combination of therapies. Significant correlations were seen between the assessment tools in the diet alone category for both months for; vitamins A, C, E, selenium and protein and for EFR1 for zinc and energy. In both months greater numbers of children achieved $\geq 100 \%$ of requirements for diet + VMS (EFR 1; $p<0.05$; EFR2 $p<0.05$ ) than for other feeding modes. Vitamin C achieved the highest intakes compared to the RNI at $773 \%$ (EFR1) and $829 \%$ (EFR2). Intakes above $200 \%$ of the RNI were seen for vitamins A, C, E, selenium and zinc. No significant differences were seen between modes of feeding in either month for selenium or zinc. Vitamin A (EFR1 $100 \%$ diet alone $\mathrm{p}<0.05)$ and zinc (EFR $1 \leq 100 \%$ diet alone $\mathrm{p}=0.02$ ) met the least of the LRNI in the $1^{\text {st }}$ month compared to other antioxidants. No statistical significant difference was observed between the number of children attaining their EAR's between the 3 modes of feeding in the $1^{\text {st }}$ month and $3^{\text {rd }}$ month. In the $1^{\text {st }}$ month $27 \%(n=8)$ of participants consumed vitamin and/or mineral supplements, $18 \%$ in the $3^{\text {rd }}$ month $(n=4)$. In the $1^{\text {st }}$ month $5 \%$ $(n=2)$ of children were moderately malnourished and $10 \%(n=4)$ in $3^{\text {rd }}$ month. Conversely in the $1^{\text {st }}$ month $3 \%(n=1)$ were overweight and $3 \%(n=1)$ obese; the leukaemia group predominant.

Conclusion: The research tools showed good correlation. Children using vitamin and/or mineral supplements mostly achieved their RNl's compared to other feeding modes. Across feeding modes some children achieved antioxidant intakes above $200 \%$ RNI. LRNI's on diet alone were not 
achieved for vitamin A and zinc. The study showed Leukaemics as having a higher prevalence of obesity. More research is required to determine the clinical implications of these findings. 


\section{OPSOMMING}

Agtergrond: Die rol van anti-oksidante en voldoende voeding in die voorkoming en verloop van kanker behandeling word wêreldwyd erken vir vernietiging van die effek van vry radikale en die verbetering van voedingstatus van kinders tydens behandeling.

Doelwit: Om ondersoek in te stel of kinders met kanker hul Dieet Verwysingswaardes en Veilige Innames vir anti-oksidante, energie en proteïen bereik.

Ontwerp: Enkel sentrum prospektiewe studie.

Omgewing: Kinders was gewerf deur middel van gerieflikheidsteekproefneming oor 8 maande vanaf die "East of England Primary Treatment Centre". Twee-en-veertig kinders en adolessente gediagnoseer met 'n Soliede tumor, Limfoom of Leukemie het in aanmerking gekom vir dataanalise ( $n=20$ manlik, $n=22$ vroulik).

Metode: Data was ingesamel met 'n Geskatte Voedsel Rekord (GVR) in die eerste (GVR1) en derde maand (GVR2) na diagnose. In die week na voltooiing van die GVR is ouers en/of kinders gekontak om vier onopeenvolgende dae van 24-uur herroepe te voltooi. Data was verdeel in dieet alleen, dieet + voedsel supplement (VS), buisvoeding (buis) of dieet + multi-vitamien-mineraal supplementasie (VMS). Wanvoeding was bepaal deur middel van gewig-vir-ouderdom z-tellings. Nutriënt inname was vergelyk met die Aanbevole Nutriënt Inname (ANI), die Geskatte Gemiddelde Behoeftes (GGB) en die Laer Aanbevole Nutriënt Inname (LANI).

Resultate: Die steekproef het bestaan uit 33\% $(n=14)$ gediagnoseer met Leukemie, 24\% $(n=10)$ Limfoom en $43 \%(n=18)$ Soliede tumore. Sewe-en-sestig persent $(n=28)$ het chemoterapie ontvang en $33 \%(n=14)$ ' $n$ kombinasie van terapieë. Betekenisvolle korrelasies was waargeneem tussen die assesseringsinstrumente in die dieet alleen kategorie vir beide maande vir vitamiene $A, C, E$, selenium en proteïen en vir GVR1 ook vir sink en energie. In beide maande het 'n groter aantal kinders $\geq 100 \%$ van hul behoeftes bereik vr dieet+VMS (GVR1; $p<0.05$; GVR2 $p<0.05$ ) as vir ander modi van voeding. Vitamien $\mathrm{C}$ het die hoogste innames bereik vergeleke met die ANI teen $773 \%$ (GVR1) en $829 \%$ (GVR2). Innames bo $200 \%$ van die ANI was waargeneem vir vitamiene A, C, E, selenium en sink. Geen betekenisvolle verskille was waargeneem tussen modi van voeding in enige maand vir selenium en sink nie. Vitamien A (GVR1 $\leq 100 \%$ dieet alleen $p<0.05)$ en sink (GVR1 $\leq 100 \%$ dieet alleen $\mathrm{p}=0.02$ ) het die minste van die LANI bereik in die eerste maand vergeleke met ander anti-oksidante. Geen statisties beduidende verskil was waargeneem tussen die aantal kinders wat hul GGB's bereik het tussen die 3 voedingswyses in die eerste en derde maande nie. In die eerste maand het $27 \%(n=8)$ van deelnemers vitamien en/of mineraal supplemente ingeneem, en $18 \%(n=4)$ in die derde maand. In die eerste maand was $5 \%(n=2)$ van kinders matig wangevoed en $10 \%(n=4)$ in die derde maand. In die eerste maand was $3 \%(n=1)$ van kinders oorgewig en $3 \%(n=1)$ vetsugtig, die leukemie groep spesifiek.

Gevolgtrekking: Die navorsingsinstrumente het goeie korrelasie getoon. Kinders wat vitamien en/of mineraal supplemente gebruik het het meestal hul ANI's bereik vergeleke met ander modi 
van voeding. Oor voeding modi het sommige kinders anti-oksidant innames bo $200 \%$ ANI bereik. LANI's op dieet alleen was nie bereik vir Vitamien A en sink nie. Hierdie studie het aangetoon dat dié met Leukemia ' $n$ hoër prevalensie van oorgewig/vetsug getoon het. Meer navorsing is nodig om die kliniese implikasies van die bevindinge te bepaal. 


\section{ACKNOWLEDGEMENTS}

This research project would not have been possible without the support of many people. I would like to show my deepest gratitude to my parents, John, Graham and Chris Forster who have been incredibly supportive, and encouraging. Further I wish to express my gratitude to my supervisors, Dr Rosan Meyer and Janicke Visser, who have been incredibly supportive and efficient in advising me. I would also like to thank my colleagues and friends, Jane Emerton, Laura Mcgeeney, Dr Amos Burke, Dr Ken Ong, and Isla Kuhn for their invaluable assistance, support and guidance.

Further thanks are extended to the Department of Paediatric Haematology and Oncology, Addenbrookes Hospital (Cambridge University Hospitals NHS Foundation Trust).

\section{DEDICATION:}

\section{Dedication to the children treated for cancer at Addenbrookes Hospital}

As I grow to understand life less and less,

I learn to love it more and more.

Jules Rena

\section{CONTRIBUTIONS BY PRINCIPAL RESEARCHER, STATISTICIAN AND SUPERVISORS}

The principal researcher (Sonja Slegtenhorst) developed the idea and the study protocol. The principal researcher planned the study, undertook data collection, captured the data for analysis, analysed the data with the assistance of a statistician (Prof DG Nel), interpreted the data and drafted the thesis. Mrs Janicke Visser and Dr Rosan Meyer (Supervisors) provided input at all stages and revised the protocol and thesis 


\section{TABLE OF CONTENTS}

Declaration

page

Abstract

Opsomming

Acknowledgements

Dedication

List of tables

List of figures

List of addenda

List of abbreviations

xii

xiii

CHAPTER 1: LITERATURE REVIEW AND MOTIVATION FOR THE STUDY CANCER TREATMENT

1.2.1 Conclusions: Role of Reactive Oxygen Species and Antioxidants in Cancer Treatment

\subsection{NUTRITION OF THE CHILD WITH CANCER}


$\begin{array}{lll}2.4 & \text { Measurement of malnutrition } & 27\end{array}$

$\begin{array}{lll}2.5 & \text { DATA ANALYSIS } & 27\end{array}$

$\begin{array}{lll}2.6 & \text { ETHICAL APPROVAL } & 30\end{array}$

CHAPTER 3: RESULTS 32

$3.1 \quad$ DESCRIPTION OF STUDY 33

3.1.1 MAIN STUDY RESULTS 33

3.1.1.1 Patient demographics 33

3.1.1.2 Nutritional Status $\quad 35$

3.1.1.3 Validity of dietary intake methods 39

3.1.1.3.1 Correlation of Dietary Tools for Antioxidant Intake 39

3.1.1.3.2 Correlation of Dietary Tools for Energy and Protein Intake 41

3.1.1.4 Comparison of Antioxidant Intakes to Dietary Reference Values 42 and Safe Intakes

3.1.1.4.1 Recommended Nutrient Intake and Safe Intake for antioxidants 42

3.1.1.4.2 Lower Recommended Nutrient Intake for antioxidants 46

3.1.1.4.3 Comparison of energy and protein intake to Estimated Average 47 Requirement

3.1.1.5 Fat-soluble vitamins (A and E) and Safe Upper Intakes 49

3.1.1.6 Prevalence and type of vitamin and/or mineral supplement use 49

CHAPTER 4: DISCUSSON

$\begin{array}{lll}4.1 & \text { INITIAL OBSERVATIONS } & 51\end{array}$

$\begin{array}{lll}4.2 & \text { OUTCOMES } & 51\end{array}$

4.2.1 Assessment of dietary intake 51

4.2.2 Nutritional status 53

4.2.3 Nutritional requirement and nutritional support 56

4.2.4 Vitamin and/or mineral supplementation 59

CHAPTER 5: CONCLUSIONS AND RECOMMEDATIONS 60

REFERENCES $\quad 64$

$\begin{array}{ll}\text { ADDENDA } & 70\end{array}$ 


\section{LIST OF TABLES}

Chapter 1

page

Table 1:1 Antioxidants and/or derivatives and unit of measurement

Table 1.2 Types of childhood cancers associated with nutritional risk

Chapter 2

Table 2:1 Summary of measurements for antioxidants used in data analysis

Table 2.2 Mode of feeding categories and abbreviations used in study

\section{Chapter 3}

Table 3.1 Demographic data and characteristics of children recruited to the study

Table 3.2: $\quad$ Mode of feeding for Estimated Food Record and 24-hr recall ( $1^{\text {st }}$ month)

Table 3.3: $\quad$ Mode of feeding for Estimated Food Record and 24-hr recall ( $3^{\text {rd }}$ month)

Table 3:4 Summary of children's diagnosis and corresponding nutritional risk

Table 3:5 Correlation of the Estimated Food Record and 24-hr recalls for mode and antioxidants ( $1^{\text {st }}$ and $3^{\text {rd }}$ month)

Table 3.6: Correlation of the Estimated Food Record and 24-hr recalls for mode of feeding and energy and protein intake $\left(1^{\text {st }}\right.$ and $3^{\text {rd }}$ month $)$

Table 3.7 Percentage of children achieving $\geq 100 \%$ and $\geq 200 \%$ of

Recommended Nutrient Intake for antioxidants

Table 3:8 Chi-square test comparing children's intake of Recommended

Nutrient Intake between feeding modes in the $1^{\text {st }}$ and $3^{\text {rd }}$ month ( $\mathrm{p}$-value)

Table 3.9 Fisher Exact test comparing children achieving the Recommended

Nutrient Intake between the1st and $3^{\text {rd }}$ month for feeding mode

Table 3.10 Percentage of children achieving $\leq 100 \%$ of the Lower Recommended

Nutrient Intakes for antioxidants

Table 3.11 Chi-square test comparing children's intake of Lower Recommended

Nutrient Intake between feeding modes in the $1^{\text {st }}$ and $3^{\text {rd }}$ month ( $p$-value)

Table 3.12 Fisher Exact test comparing children achieving the Lower Recommended

Nutrient Intake between the 1 st and $3^{\text {rd }}$ month for feeding mode ( $p$-value)

Table 3.13 Percentage of children achieving $\geq 100 \%$ and $\geq 200 \%$ of their Estimated

Average Requirement for energy and protein

Table 3.14 Chi-square test comparing children's intake of energy and protein

between feeding modes in the $1^{\text {st }}$ and $3^{\text {rd }}$ month ( $p$-value

Table 3.15 Fisher Exact test comparing children achieving their energy and

Protein between the 1 st and $3^{\text {rd }}$ month for feeding mode ( $p$-value)

Table 3.16 Frequency of use of multivitamin-mineral and vitamin supplements in 


\section{LIST OF FIGURES}

Chapter 1

page

Figure 1.1 Main reactive oxygen species constantly generated in living cells

Figure 1.2 Schematic representations of pathways illustrating the sources of

Reactive oxygen species and its role in the development of cancer

Figure 1.3 Schematic representation of apoptosis and antioxidants in cancer

Figure 1.4 Definitions of Dietary Reference Values

\section{Chapter 2}

Figure 2.1 Diagrammatical representation of the specific objectives

Figure 2.2 Diagrammatical representation of data collection

\section{Chapter 3}

Figure 3.1 Grouping of z-scores for weight-for-age at initial assessment ( $1^{\text {st }}$ month) and follow up ( $3^{\text {rd }}$ month)

Figure 3.2 Malnutrition z-scores for children with Solid tumours, Lymphoma and Leukaemia at initial assessment ( $1^{\text {st }}$ month) and follow up ( $3^{\text {rd }}$ month) 


\section{LIST OF ADDENDA}

page

Addendum A Summary of each antioxidants function, source, nutritional state and requirement

Addendum B Dietary Reference Values for vitamin A, C, selenium and zinc and safe intakes for vitamin $\mathrm{E}$

Addendum C Estimated average requirements for energy and protein 76

$\begin{array}{lll}\text { Addendum D } & \text { Safe Upper Intakes for vitamin A and E } & 77\end{array}$

$\begin{array}{lll}\text { Addendum E } & \text { Invitation letter to study } & 78\end{array}$

$\begin{array}{lll}\text { Addendum F } & 79\end{array}$

Addendum $G \quad$ Consent form $\quad 92$

$\begin{array}{lll}\text { Addendum H } & \text { Estimated Food Record } & 94\end{array}$

$\begin{array}{lll}\text { Addendum I 24-hr recall } & 98\end{array}$

Addendum J Nutritional support algorithm (Addenbrookes Hospital) 99

$\begin{array}{lll}\text { Addendum K } & \text { Critique forms } & 100\end{array}$

Addendum L Approval letter for Human Research Committee of 102

Addendum M Approval letter for Hertfordshire Research Ethics 103

Addendum N Comparison of antioxidant intakes to the Dietary Reference 109

Values and Safe Intakes ( $1^{\text {st }}$ and $3^{\text {rd }}$ month)

Addendum $\mathrm{C} \quad$ Comparison of antioxidant intakes to the Lower Recommended 112 Nutrient Intakes ( $1^{\text {st }}$ and $3^{\text {rd }}$ month)

Addendum $\mathrm{P} \quad$ Comparison of energy and protein to the Estimate Average Requirements ( $1^{\text {st }}$ and $3^{\text {rd }}$ month) 


\section{LIST OF ABBREVIATIONS}

ALL Acute lymphoblastic leukaemia

ATBCCPS Alpha-tocopherol beta carotene cancer prevention study

BAPEN British association for parenteral and enteral nutrition

BMI Body mass index

CAM Complementary and alternative methods

CARET Beta carotene and retinol efficacy trial

DOH (UK) Department of Health in the United Kingdom

UV Ultra violet

DRV Dietary Reference Intake

EAR Estimated average requirement

EFR Estimated food record

FAO Food and agricultural organization

FFQ Food frequency questionnaire

FS Food supplement

GFR Glomerular filtration rate

GSHPX Cellular gluthathione peroxidise

IGF-1 Insulin-like growth factor-1

LRNI Lower Recommended Nutrient Intake

MUAC Mid-upper arm circumference

MVMS Multi -vitamin and mineral supplement

NHS National Health Service

$\mathrm{OH}^{-} \quad$ Reactive hydroxyl acid

ORAC Oxygen radical absorbance capacity

8-oxo-dG 8-Oxo-2'-deoxyguanosine

$\mathrm{PI} \quad$ Primary Investigator

PEG Percutaneous endoscopic gastrostomy

PN Parenteral nutrition

POIG Paediatric oncology dietitians interest group

RDA Recommended Daily Allowance

$\mathrm{RNI} \quad$ Recommended Nutrient Intake

SD Standard deviation

Se Selenium

SNR Swedish Nutrition Recommendations

SOD Superoxide dismutase

TAC Total antioxidant capacity

UK United Kingdom 
VS Vitamin Supplement

WHO World Health Organization 
CHAPTER 1: LITERATURE REVIEW AND MOTIVATION FOR THE STUDY 


\section{INTRODUCTION}

The role of antioxidants and adequate nutrition in the prevention and course of cancer treatment is globally recognised. This is due to the unique role antioxidants play in nullifying the effects of free radicals and the considerable benefits seen in well-nourished children and adults during cancer treatment. $^{(1-3)}$

It is known that cancer in itself, not withstanding cancer treatment, induces a high incidence of malnutrition. The incidence of malnutrition in children with cancer is said to range from $6 \%$ to $50 \%$ depending on the type, stage and location of the tumour. ${ }^{(4,5)}$ Malnutrition has been shown to result in a poorer outcome compared to a well-nourished child at diagnosis and during treatment. ${ }^{(2,6,7)}$ Although the importance and benefits of optimal nutritional status during treatment is known equally the dilemma lies in providing a sufficient or excessive intake of antioxidants that could compromise the efficacy of cancer treatment itself..$^{(5,8-12)}$ Antioxidants have the potential to reverse the cancer treatment's action of increasing free radical production and killing cancer cells. ${ }^{(3)}$ There are numerous adult studies showing the effects of antioxidants in cancer treatment however there are still very few in the paediatric population. ${ }^{(6)}$ Currently few paediatric studies exist looking at the effects of antioxidants in cancer treatment. Though many adult studies exist it is often difficult to extrapolate data due to the different nature of cancer types, treatments, requirements of antioxidants and also taking into account factors such as the different ages of the child. Consequently very little data providing actual references for the requirements of antioxidants during cancer treatment for a child is available. Authors have proposed that there is a clinical need for increased intakes of antioxidants compared to the Recommended Dietary Allowance (RDA), Recommended Nutrient Intake (RNI) and Estimated Average Requirement (EAR) during cancer treatment; however there are no studies available to substantiate what these requirements should be. ${ }^{(12)}$

The main aim of providing this increased nutritional support in the cancer patient is to promote and achieve desirable weight gain and to prevent or correct nutritional deficiencies. Individualised counselling on the potential nutritional problems related to the location of the tumour and cancer staging is discussed with the patient and family. The implications of malnutrition in comparison to well-nourished children during treatment are noteworthy. Children on intense treatments are at higher risk of nutritional morbidity as well as higher infection rates, worse outcomes, impaired tolerance to chemotherapy, impaired immune function and the need for more frequent chemotherapy dose adjustments. ${ }^{(5,8-10,12-14)}$ All of these risk factors a significant impact on length of treatment, number of admissions, quality of life, the efficacy of treatment and hence outcome as well. It could therefore be suggested that adequate nutritional support improves overall outcome in the paediatric oncology patient with regard to patient outcome and cost to the National Health 
Service (NHS). As such the chairman of the British Association for Parenteral and Enteral Nutrition (BAPEN UK) stated that 'Good nutritional care also makes sound financial sense. BAPEN has estimated that public expenditure on malnutrition in the UK in 2007 was over $£ 13$ billion and so consequently improved nutritional care could result in substantial financial returns; a $1 \%$ saving could amount to approximately $£ 130$ million per year. These results are also inclusive of adult data. Therefore not only are we mindful of the implications it has for the actual patients outcome but for the NHS service as well. ${ }^{(15)}$

The supplementation of antioxidants during cancer treatment remains a controversial topic. The possible benefits of antioxidants for a child during cancer treatment seem intuitive, yet the implications of negating this very treatment could offer a poorer outcome. Due to the limited data available to support the recommendation and level of dosing of antioxidants during cancer treatment, it leaves this topic in a state of controversy. Kennedy et al. ${ }^{(11)}$ advised that supplementation during treatment of antioxidants was not advocated due to the probable interference with cancer treatment, even though their study showed that the population group did not meet recommended dietary intake.

This study therefore set out to establish the actual dietary intake of antioxidants in this paediatric oncology population. The purpose was to determine whether the children were meeting the United Kingdom Department of Health's (DOH UK) antioxidant, energy and protein requirements for healthy children, ${ }^{(16)}$ which is needed to maintain normal body functioning. No national guidelines exist for the requirement of antioxidants in the paediatric oncology population. Further to this the prevalence of vitamin-mineral supplementation and the doses given were investigated to establish over and under supplementation. From the latter investigations one could hypothesise whether there was the potential that excessive amounts of antioxidants could interfere with treatment. 


\subsection{ROLE OF REACTIVE OXYGEN SPECIES AND ANTIOXIDANTS IN CANCER TREATMENT}

It is important to understand the unique role that antioxidants play in the neutralization of free radicals and how this impacts on a child's tolerance and response to cancer treatment. An antioxidant is defined as a substance that inhibits the reactions of free radicals such as reactive oxygen species (ROS). ${ }^{(17)}$ This is used to describe vitamin $A, E, C$, ubiquinones and bioflavonoids. ${ }^{(17)}$ The antioxidants and units of measurement researched in this study are documented in Table 1.1.

Table 1.1 Antioxidants and/or derivatives and unit of measurement

\begin{tabular}{|c|c|c|}
\hline Antioxidant & Derivative & Measurement unit \\
\hline Vitamin A & Retinol equivalents & ug (microgram) \\
\hline Vitamin E & a- tocopherol & mg (milligram) \\
\hline Vitamin C/ascorbic acid & N/A & mg (milligram) \\
\hline Zinc & N/A & mg (milligram) \\
\hline Selenium & N/A & ug (microgram) \\
\hline
\end{tabular}

On the other hand reactive oxygen species (ROS) are metabolites of molecular oxygen and are constantly produced in our cells (Figure 1.1). ${ }^{(15)}$ ROS includes superoxide anion radical $\left(\mathrm{O}_{2}^{-}\right)$, singlet oxygen $\left({ }^{1} \mathrm{O}_{2}\right)$, hydrogen peroxide $\left(\mathrm{H}_{2} \mathrm{O}_{2}\right)$, nitric oxide $\left(\mathrm{NO}^{+}\right)$and the highly reactive hydroxyl radical $(\mathrm{OH})$. Free radicals are said to damage cells and may contribute to the development of cancer and cardiovascular disease. ${ }^{(18)}$

\begin{tabular}{|c|}
\hline Reactive Oxygen Species (ROS) \\
$\mathrm{O}_{2}^{-}$Superoxide ${ }^{+}$ \\
$\mathrm{H}_{2} \mathrm{O}_{2}$ Hydrogen Peroxide \\
$\mathrm{OH}^{+}$Hydroxyl Radical \\
\hline Reactive Nitrogen Species \\
$\mathrm{NO}^{+}$Nitric Oxide \\
$\mathrm{NO}_{2}$ Nitrogen Dioxide \\
$\mathrm{ONOO}$ Peroxynitrite \\
\hline
\end{tabular}

Figure 1.1 Main reactive oxygen species constantly generated in living cells. ${ }^{(3)}$ 
These ROS are produced through mitochondrial respiration involving the electron transport chain and the reduction of oxygen molecules to superoxides. ${ }^{(15)}$ Alternatively, hydrogen peroxide can be converted into water by the enzyme catalase or glutathione peroxidase. Sources of exogenous sources of free radicals include chemicals, pollutants, ultra violet (UV) and radiation (Figure 1.2). ${ }^{(3)}$

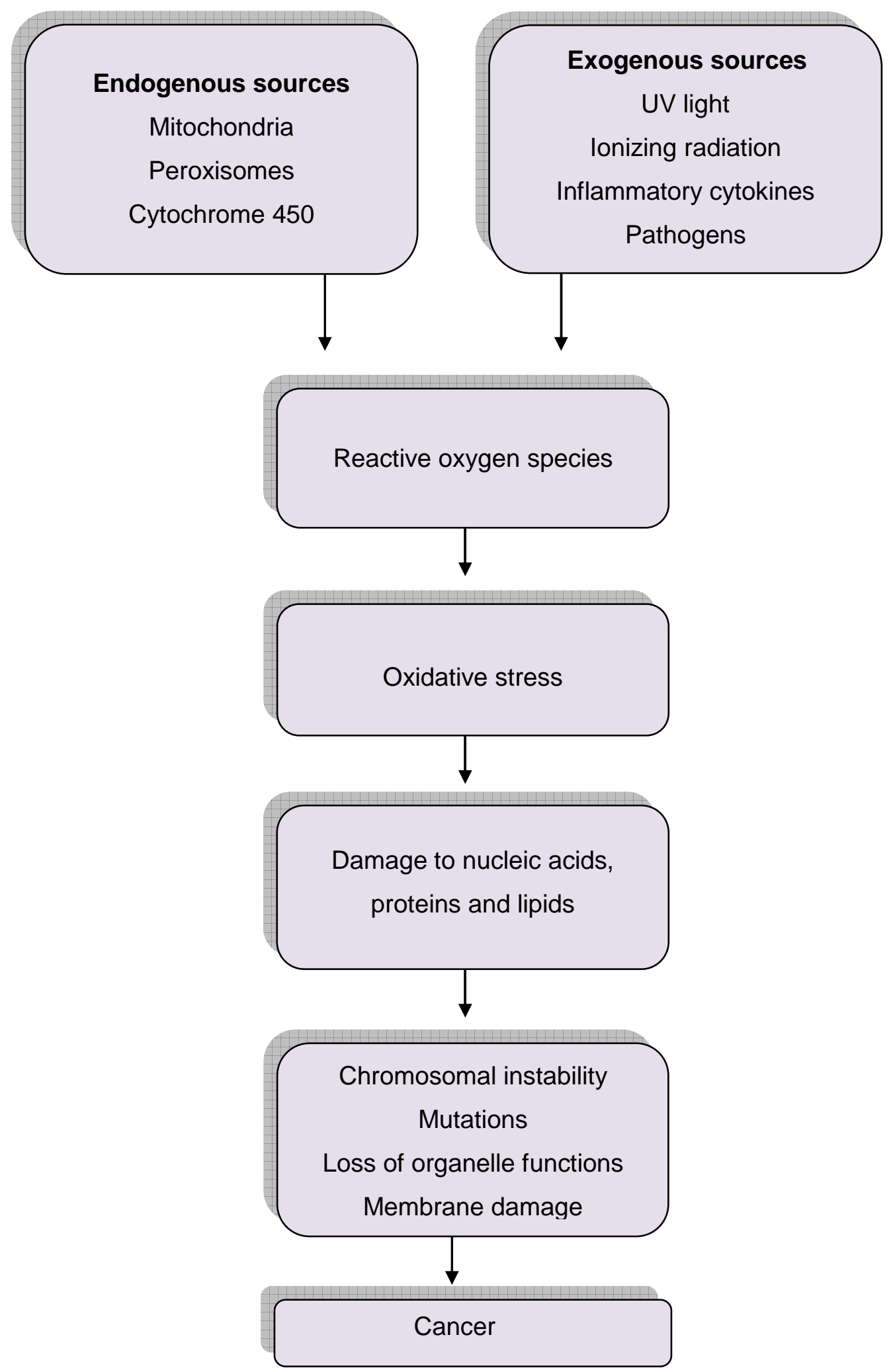

Figure 1.2 Schematic representations of pathways illustrating sources of reactive oxygen species and role in the development of cancer ${ }^{(19)}$ 
ROS are renowned for its role in causing tissue damage by reacting with lipids in cell membranes, nucleotides in DNA (Deoxy-ribose nucleic acid), sulphydryl groups in proteins and cross-linking fragmentation of ribo-nucleoproteins (RNA). This is generally seen when the internal equilibrium of ROS redox balance is disturbed (Figure 1.2). ${ }^{(20-22)}$ However, ROS are not always harmful if tightly controlled at moderate levels. At these moderate levels ROS functions effectively in intracellular signalling molecules and in apoptosis, phagocytosis and detoxification reactions (protective mechanisms)..$^{(3,19)}$ Apoptosis occurs when the internal body detectors recognise damage or malfunction and initiate signalling cascades that eventually activate caspases and endonucleases that kill the cell. The most significant function of apoptosis is the elimination of pre-cancer and cancer cells; however antioxidants such as a-tocopherol (vitamin E) and others have the potential to inhibit apoptosis (Figure 1.3). ${ }^{(23)}$ This has been demonstrated in animal studies performed at the University of North Carolina at Chapel Hill. Transgenic mice developing brain tumours were fed a diet depleted of antioxidants, while control mice were fed a standard diet. The antioxidant-depleted group showed a significant increase in ROS in their brain tumour cells and therefore a dramatic increase in apoptotic death of these cells. Due to the intensive apoptosis, a sharp decrease in tumour volume resulted. Similar results were obtained in transgenic mice developing mammary tumours. This data indicates that antioxidants scavenging ROS can interfere with cancer cell-killing apoptosis. ${ }^{(24)}$

In general, normal human cells contain antioxidant enzymes (e.g. superoxide dismutase, catalase, and glutathione peroxidase). This is in contrast to human cancer cell types that characteristically have lower antioxidant enzyme levels, but instead have significantly higher concentrations of ROS. It is therefore thought that some cancer cells may be more sensitive to changes of generated ROS, which could then be utilized when actively seeking to kill cancer cells and spare normal cells. This is evidenced in the use of certain chemotherapy agents used to overcome the oxidative stress mechanisms of the cancer cell by increased production of ROS. ${ }^{(25)}$ Many classes of anticancer agents are known to produce a high level of oxidative stress in biological systems. ${ }^{(20,26)}$ These drugs include the anthracyclines (e.g. Doxorubicin), platinum-coordination complexes (e.g. Cisplatin, carboplatin), epipodophyllotoxins, most alkylating agents (e.g. Cyclophosphamide, Ifosphamide), and cytotoxic antibiotics (e.g. Bleomycin, mitomycin-C). ${ }^{(11,19,27)}$ Other drug classes such as taxanes, vinca alkaloids, anti-folates and nucleosides only generate low levels of free radicals. ${ }^{(28)}$

In contrast radiation's main therapeutic effect occurs indirectly via the ionization of water molecules in the cytoplasm to ROS for example superoxide and hydroxyl radicals. These free radicals react with nuclear DNA, therefore forming structural bonds that are potentially fatal to cells. Cancer cells have the ability to repair radiation damage; therefore cells that remain viable can proliferate. This shows the importance of combination therapies in the treatment of cancer. ${ }^{(29)}$ This poses a difficult 
decision for health care professionals as to whether adequate antioxidants in the diet and/or supplementation should be advocated or not. Its ability in improving tolerance of treatment is known; however at the same time one has to be conscious of the effects it has on vital treatment.

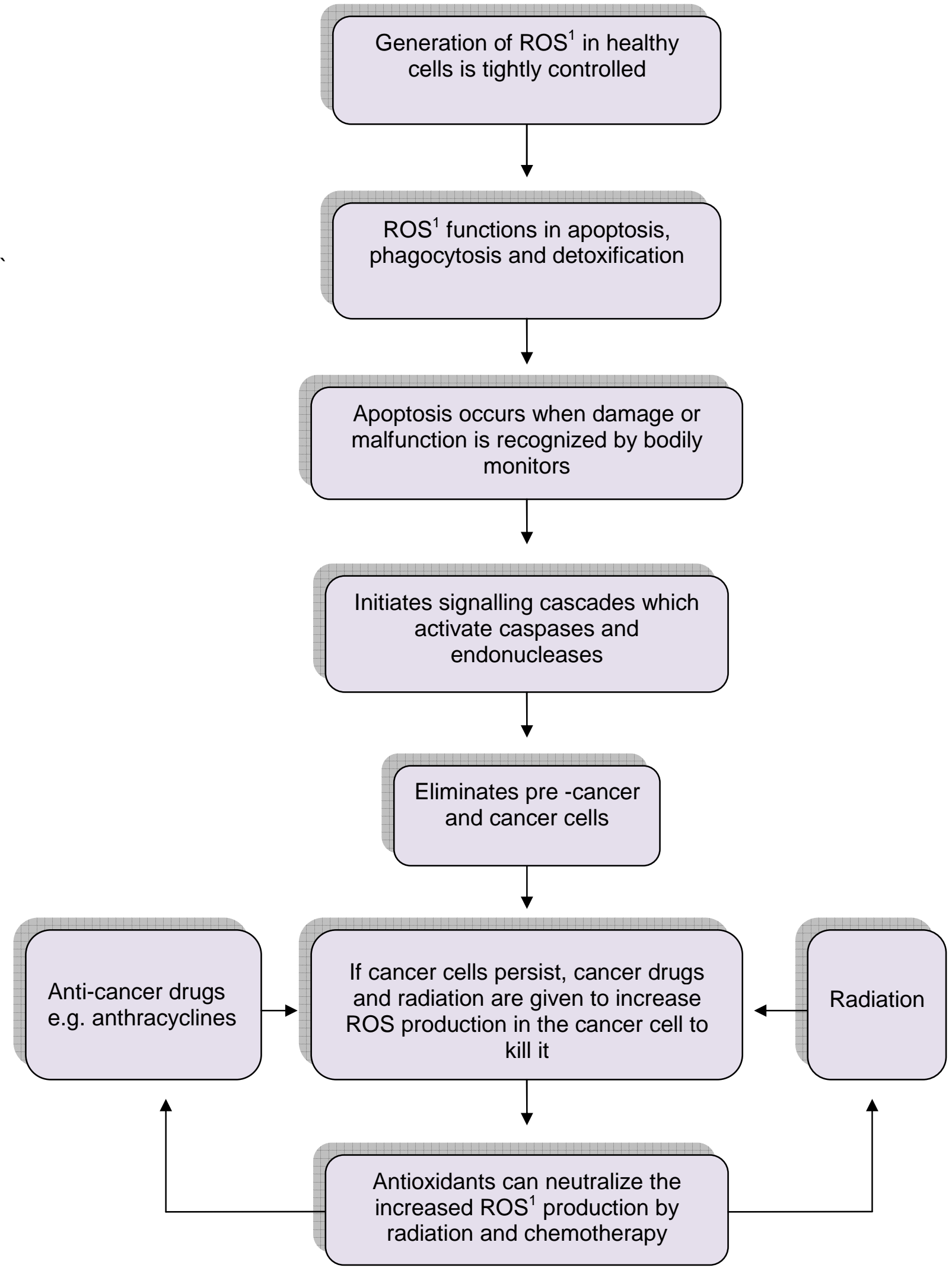

${ }^{1}$ ROS - reactive oxygen species

Figure 1.3 Schematic representation of apoptosis and antioxidants in cancer treatment 
Taking into account all the processes that antioxidants are involved in it would be reasonable to hypothesise that antioxidants could become depleted if not adequately replenished. This is supported by the following studies: a systematic review performed by Ladas et al. ${ }^{(6)}$ supported the hypothesis that chemotherapy lowered total antioxidants status, but this was assessed in a limited number of observational studies only and no randomized control trials. Malvy et al. ${ }^{(26,30)}$ showed that in general, the mean serum concentrations of retinol, $\beta$-carotene, zinc, $\alpha$-tocopherol, and cholesterol were lower in cancer cases than controls; however there were some differences in micronutrient deficiencies by tumour type. It was suggested that this could be attributed to changed biosynthesis in the liver high receptor mediated intake and degradation by malignant cells, production of ROS by radiation and chemotherapy, inadequate intake and activated granulocytes. ${ }^{(20)}$ Interestingly when higher plasma concentrations of Oxygen Radical Absorbance Capacity (ORAC), vitamin A, E, total carotenoids and 8-oxodeoxyguanosine were seen in children with Acute Lymphoblastic Leukaemia (ALL) a positive association was found with fewer infections improved quality of life, decreased toxicity and decreased length of admission. ${ }^{(4,7,11)}$

Very few studies had investigated the role of selenium and zinc as antioxidants in the paediatric oncology setting. Studies that were available found that at diagnosis children had low serum selenium values except for those on corticosteroid treatment, who had raised selenium levels. ${ }^{(31-33)}$ It was concluded that selenium deficiency was common among newly diagnosed children with cancer and lower in widespread disease than localized disease. ${ }^{(32,33)}$ It was suggested by Koskelo that the endogenous selenium store redistributed itself later in the treatment period therefore serum selenium may not be a valid indicator of selenium status. ${ }^{(31)}$ In the case of zinc it was found that long-term deficiency was associated with malignant lymphomas (Burkitts and Hodgkin's) and that this persisted for years. The study showed that tumour necrosis factor- $\alpha$ and interleukin $1-\beta$ increased in zinc deficient cells therefore causing activation of monocytes and macrophages involved in ROS generation. It was therefore thought that zinc could function as an effective antioxidant. ${ }^{(34)}$ Interestingly in the study by Gokhale on the post therapy profile of serum retinol, zinc and serum total cholesterol, it was found that children had comparable serum levels to that of controls. ${ }^{(35)}$ Therefore cancer and its treatment did not have any long-lasting effect on the latter nutrients.

Despite ongoing research on the effect of antioxidants on cancer treatment, a systemic review of randomized trials by Ladas et al. ${ }^{(6)}$ could not draw a definitive conclusion as to the safety and efficacy of antioxidant interventions. This was most probably due to the broad range of chemotherapy regimes, antioxidant supplementation and cancer diagnoses. 


\subsubsection{CONCLUSIONS: ROLE OF REACTIVE OXYGEN SPECIES AND ANTIOXIDANTS IN CANCER TREATMENT}

At this stage most oncologists and dietitians would still discourage children and parents from using antioxidants as additional supplements during treatment due to the controversial nature of antioxidants and cancer treatment. ${ }^{(25)}$ There is consequently a great dilemma: a child requires adequate antioxidants to meet and not exceed the RNI during cancer treatment, however oral intake is compromised and deficiencies are common during treatment. Should healthcare professionals therefore recommend antioxidant supplements to achieve RNI's but risk interfering with the treatment?

\subsection{NUTRITION IN THE CHILD WITH CANCER}

\subsubsection{REQUIREMENTS FOR ANTIOXIDANTS, ENERGY AND PROTEINS}

Due to the limited data available for the requirements of antioxidants in the paediatric oncology patient, it would be reasonable to use the $\mathrm{DOH}(\mathrm{UK})$ report outlining the Dietary Reference Intakes (DRV) for children. ${ }^{(16)}$ Though much of this work is extrapolated from adults and is based on healthy individuals, it still provides a baseline for assessing this study's antioxidant intakes. It is still worthy to note that these requirements do not take into account different disease processes and how this may affect the requirements. The report by the DOH (UK) in 1991 defines the DRV as comprising of the following components namely; Estimated average requirement (EAR), Recommended nutrient requirement (RNI) and Lower recommended nutrient intake (LRNI). Each of these nutritional requirement categories are said to fulfil specific parameters in a healthy population of children. In this study the RNI will be used to compare the children's daily nutritional intakes. The RNI is suitable to estimate the intake of individuals so as to meet $97.5 \%$ of healthy individuals in a population group's requirements. ${ }^{(16)}$ Depicted in Figure 1.4 is an illustration of how the dietary reference values meet the populations' requirements. ${ }^{(16)}$ 


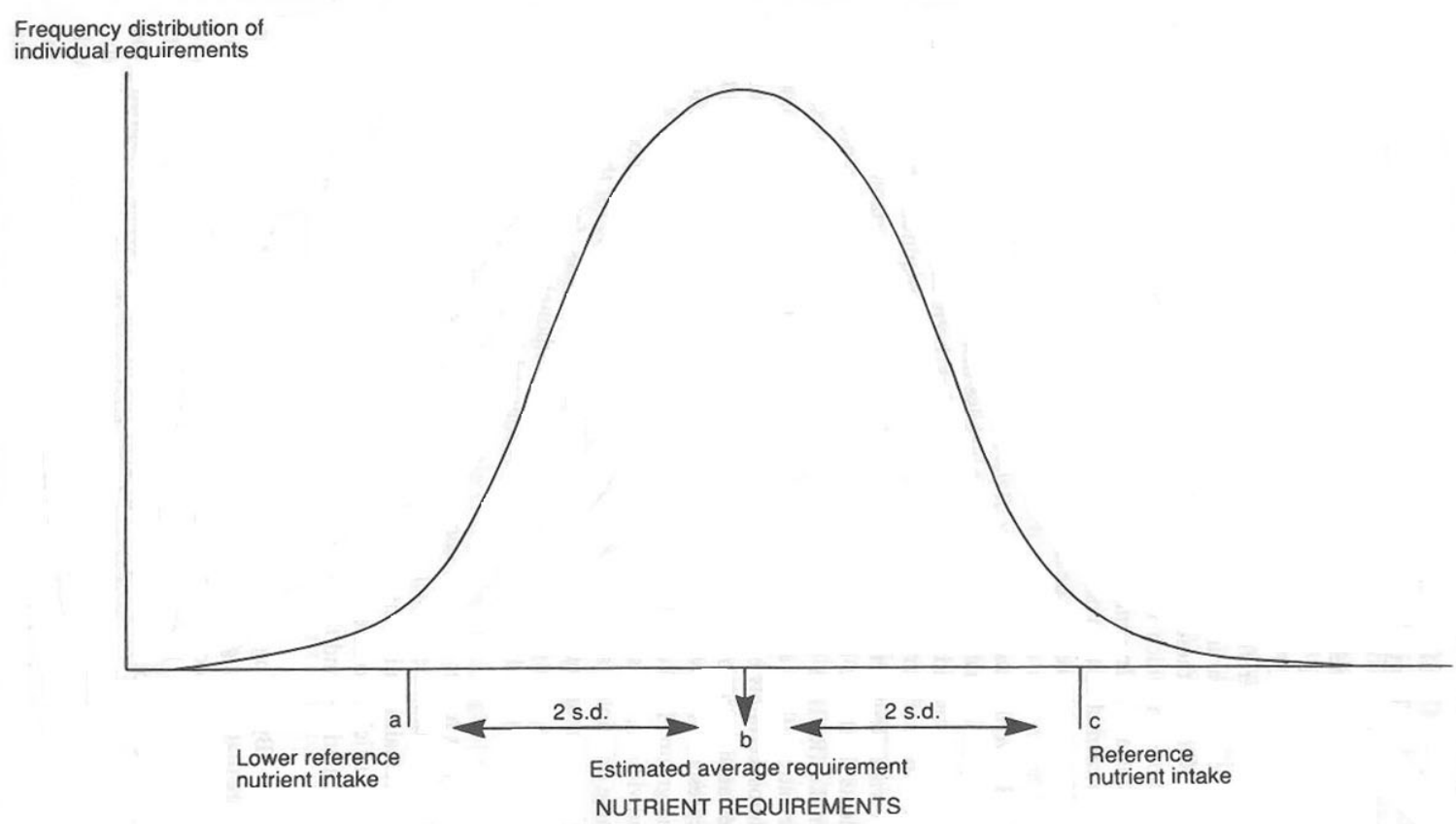

Figure 1.4 Definitions of Dietary Reference Values.

(Reprinted with permission from the Department of Health $(\mathrm{UK})^{(16)}$

As reported by the $\mathrm{DOH}(\mathrm{UK}),{ }^{(16)}$ data is usually insufficient to calculate the exact distribution of requirements in a group of individuals for a nutrient, therefore it is assumed to be normally distributed (Figure 1.4). This gives an assumed/notional mean requirement or EAR with the interindividual variability in requirements as seen in Figure 1.4. The panel for the $\mathrm{DOH}$ (UK) defined the $\mathrm{RNI}$ as point $\mathrm{c}$ in the distribution that is two notional standard deviations (2SD) above the EAR (point $b$ ). Intakes above this amount will almost certainly be sufficient. A further value at point $a$, is two notional standard deviations (2SD) below the mean, the Lower Reference Nutrient Intake (LRNI). This represents the lowest intake of a nutrient that will meet the needs of some individuals in the group. If the usual/habitual intake of the child is below the LRNI it is unlikely that the child will be consuming adequate amounts of the nutrient to maintain the function as an appropriate parameter of nutritional status for that nutrient. If the intake lies between the two ( $b$ and $c)$, then the chance of the intake not meeting the requirement decreases the closer the intake to the RNI. Without some biological measure, it is impossible to say without any doubt whether an individuals' nutrient intake is adequate, if it lies between the LRNI and the RNI. ${ }^{(16)}$ Due to the inaccuracy of most estimates of individuals' nutrient intakes and the assessment of nutritional status; it is important to use caution when using the estimated DRV's against an individual's. ${ }^{(16)}$ A summary of each antioxidants function, source, and nutritional state is shown in Addendum A. The DRV's for vitamin A, C, selenium, zinc and safe intake for vitamin $E$ are shown in Addendum $B$ and EAR for energy and protein in Addendum $C$. The fat-soluble vitamins ( $A$ and $E$ ) intakes were also compared against the Safe Upper Intakes (Addendum D). 
From the latter discussions we gain an appreciation of the potential and significant effects of antioxidants. This is not only in daily tightly regulated body processes, but its ability to neutralize ROS could improve a child's quality of life and nutritional morbidity during treatment. We are however thwarted by the fact that antioxidants can also impact on cancer treatments efficacy. To date health care professionals are still reluctant to supplement with antioxidants for the very fear of interfering with cancer treatment. Limited data exists in paediatric oncology patients with regard to studies providing varied doses of antioxidants to patients to determine the threshold whereby interference with cancer treatment is seen. In this study we will scrutinize the children's actual dietary intakes and compare these to the recommendations of healthy children. This will include the LRNI, RNI, DRV and safe intakes. ${ }^{(16)}$ It would be reasonable to assume that even though these children are on cancer treatment they should meet at least the LRNI and RNI and DRV for healthy body functioning and that there may be an increased requirement due increased ROS production during treatment and by the disease itself. This study will also elicit if any children are consuming excessive intakes compared to the recommendations.

\subsubsection{AETIOLOGY OF MALNUTRITION}

Severe malnutrition is more commonly seen in newly diagnosed children, relapse solid tumours and the later stages of cancer as cited by Ward. ${ }^{(1)}$ The implications of malnourished children in comparison to their well-nourished counterparts during treatment are noteworthy. Children on intense treatments are at higher risk of nutritional morbidity as well as higher infection rates, worse outcomes, impaired tolerance to chemotherapy, impaired immune function and the need for more frequent chemotherapy dose adjustments. All of the latter have a significant impact on length of treatment, number of admissions, quality of life, efficacy of treatment and outcome..$^{(5,9-14,36)}$

Malnutrition seen in both paediatrics and adult cancer patients is called cancer cachexia. This syndrome of progressive body wasting is characterized by loss of adipose tissue and skeletal muscle mass. Cachexia was shown to be more common in children with solid tumours at presentation (33\%) and during treatment (57\%) compared to children with leukaemia (12\% at presentation, $28 \%$, during treatment). ${ }^{(37)}$ It is also known that factors that contribute to an impaired nutritional status include reduced food intakes, alterations in nutrient metabolism and an increased resting expenditure. Children's food intakes whilst on cancer treatment are sensitive to the 'wax and wane' of treatment intensity, the systemic and adverse effects as well as psychological elements associated with cancer treatment. Though cancer cachexia is not fully understood; studies have shown that cytokines are involved in the aetiology and are important in the alteration of carbohydrate, lipid, and protein metabolism. Cytokines such as tumour necrosis factor, interleukin 1, 6 and y-interferon are thought to play a role in cancer cachexia, however the exact role is not yet known. ${ }^{(38,39)}$ 
The normal response expected to starvation is to conserve energy and protein reserves at the expense of endogenous carbohydrate and fats stores. This compensatory mechanism does not occur in the person with cancer. Despite a decreased protein intake the body's protein turnover increases and hence muscle catabolism takes place. Clinically this is seen as skeletal muscle atrophy and hypoalbuminemia. ${ }^{(37,40)}$ Deranged changes are also seen in lipid metabolism with a reduction in lipid stores, an increase in circulation and increased fatty acid turnover. Marked wasting of body fat and atypically raised plasma lipids are therefore observed. Increased insulin resistance and gluconeogenesis contributes to the irregularities in carbohydrate metabolism and subsequent increased glucose turnover and impaired glucose tissue clearance. ${ }^{(37,40)}$ During cancer treatment children have increased protein and energy requirements to maintain growth, which places them at greater risk of malnutrition. ${ }^{(39)}$

\subsubsection{IDENTIFYING A CHILD AT RISK OF MALNUTRITION}

The main aims during cancer treatment are to promote growth as well as prevention and reversal of malnutrition. To enable this, the use of nutritional support is required throughout the cancer treatment. Consequences of malnutrition are multiple and therefore nutrition guidance measures (Table 1.2) were developed from the two publications by Rickard et al. ${ }^{(41,42)}$ The purpose of the guidance measures was to categorise children according to tumour type and staging and subsequently whether this classed the child at high or low nutritional risk. ${ }^{(41,42)}$ 
Table 1.2 Types of childhood cancers associated with nutritional risk ${ }^{(41,42)}$

\begin{tabular}{|c|c|}
\hline High Nutritional Risk & Low Nutritional Risk \\
\hline $\begin{array}{c}\text { Advanced diseases during initial intense } \\
\text { treatment }\end{array}$ & \\
Stages III and IV Wilm's tumour and \\
unfavourable histology Wilm's tumour \\
Stages III and IV neuroblastoma \\
Ewings sarcoma \\
Pelvic rhabdomyosarcoma \\
Some Non-hodgkin's lymphoma \\
Multiple relapse leukaemia \\
Acute non-lymphoblastic leukaemia \\
Some poor prognosis Acute lymphoblastic \\
leukaemia \\
Medulloblastoma
\end{tabular}

A further useful tool to measure acute malnutrition is that of weight-for-height and weight-for-age zscores provided by the World Health Organization Global Database on Child Growth and Malnutrition. ${ }^{(43)}$ This database uses a z-score cut-off point of <-2 Standard deviations (SD) to classify low weight-for-age, low height-for-age and low weight-for-height as moderate and severe under-nutrition as <-3 SD to define severe under nutrition. A disadvantage of weight-for-age is that it fails to distinguish between short children of adequate body weight and tall, thin children. Therefore where possible weight-for-height should be used. ${ }^{(43,44)}$

Tools to measure growth and remission are further discussed in publications by Kennedy et al. and Khan et al. ${ }^{(11,13)}$ A lower weight-for-height was found to be associated with a shorter remission period in particular to ALL populations. This was however not conclusively seen in a follow up study. Though this data was seen in particular with ALL populations, it could reasonably be extrapolated to most high risk cancers. ${ }^{(11)}$ Khan et al. ${ }^{(13)}$ did not find conclusive evidence to suggest that weight-for-height is a significant prognostic tool for prognostic significance. Weight-for-height z-scores were the preferred tool to determine malnutrition in children with cancer, however in this research study weight-for-age was used. The reason for this was that not all the children were heighted on the unit in particular the 1-3 year age group, those that were immobile, and neuropathy induced by vincristine. 


\subsubsection{NUTRITION SUPPORT IN THE CHILD WITH CANCER}

Nutritional support can be defined as the provision/administration of nutrients in place of or in addition to that provided by normal eating to ensure a balanced diet. This includes interventions relating to the methods of delivery (e.g. via enteral tube feeding or parenteral route) and/or nutritional content (e.g. high density). El-Mantary, ${ }^{(45)}$ suggested that aggressive nutritional support was essential in improving the outcome in cancer patients in catabolic states. However, it is often difficult to establish adequate oral feeding despite energy dense supplements due to the underlying malignancy, in addition to the aggressive chemo- and radiotherapy. A child with cancer is largely assessed against the criteria recommended by Andrassy to determine if nutritional support is required. ${ }^{(39)}$ Based on this assessment the appropriate route of nutritional support is initiated. Criteria are as follows: ${ }^{(39)}$

a) Five to ten percent weight loss relative to pre-illness body weight.

b) Weight-for-height less than $90 \%$.

c) A decrease in current centile in weight by 2 percentile.

d) Adipose energy reserve as determined by skin fold measurement be $<50^{\text {th }}$ centile for age and gender.

e) Voluntary food intake of $<70 \%$ of estimated requirement for 5 days in the well-nourished child.

f) High nutritional risk dependent on tumour type and site.

g) Bone marrow transplantation.

h) Anticipated gut dysfunction due to treatment for 5 days in well-nourished children (parenteral nutrition).

Oral feeding is generally recommended as the first option of feeding especially for children with a low nutritional risk (Table 1.2); with the exception of those with complications such as relapse, sepsis or major abdominal procedures. The latter children may however require nasojejunal or parenteral feeding dependent on the site of trauma. Children on less intensive treatments generally don't require tube feeding or parenteral nutrition, but may require energy dense oral supplements accompanied with a multivitamin-mineral supplement. This is potentially due to poor eating, decreased variety, limited fruit and vegetable intake and slowed weight gain. ${ }^{(1)}$

Tube feeding is provided to those patients with suboptimal intake. Nasogastric and nasojejunal tubes were most frequently used for shorter term feeding whereas gastrostomy and jejunostomy feeding were suggested for longer term feeding and certain cancers in which high dose treatment was frequent and associated with vomiting. ${ }^{(45)}$ Parenteral nutrition is reserved for those children whose enteral feeding regimens cannot provide adequate nutrition, in particular children with abnormal gastrointestinal function that is related either to the tumour or a side effect of 
treatment. ${ }^{(1,46)}$ In comparison to parenteral feeding, enteral nutrition is considered to be more practical, has a lower risk of infection, maintains gut integrity and reduces the risk of bacterial translocation. ${ }^{(1,4)}$ Sala et al. ${ }^{(47)}$ and Jeejeebhoy supported enteral feeding in this cohort of patients and also mentioned that the enteral route had a greater safety, ease of administration, was more physiologic with an efficient use of nutrient substrates, decreased hepato-biliary complications and improved outcome and cost-effectiveness. ${ }^{(48)}$ Though infrequently used parenteral nutrition serves its purpose of providing sufficient nutrients to children with abnormal gastrointestinal function related to their tumour or following chemotherapy or radiotherapy treatment. ${ }^{(1)}$ It does however coincide with an increased infection risk and a supposedly could enhance tumour cell growth. ${ }^{(49,50)}$ A study by Christensen et al. ${ }^{(50)}$ showed the risk of infection was 2.4-fold greater in patients given parenteral nutrition ( $95 \%$ confidence interval 1.5 to $3.9 ; p<0.001)$.

It became evident from a study performed in three paediatric oncology units that children with specific cancer types and bone marrow transplants became severely malnourished during treatment due to significant nausea and vomiting. ${ }^{(51)}$ This had obvious implications for nasogastric feeding, and therefore Percutaneous Endoscopic Gastrostomies (PEG's) were placed at an early stage in treatment to prevent malnutrition. ${ }^{(51-53)}$ The children in particular with Medulloblastomas showed a great benefit with the early placement of PEG's and starting enteral nutrition at an early stage of treatment. ${ }^{(51)}$ Children with Medulloblastomas are prone to vomiting, constipation and develop significant nutritional problems during treatment. Treatment centres in which proactive nutrition was initiated and prophylactic gastrostomies were sited showed a superior nutritional outcome. $^{(51)}$

\subsubsection{CONCLUSION: NUTRITION OF THE CHILD WITH CANCER}

From the literature review it can be surmised that antioxidants have a controversial role to play during cancer treatment. Two particular schools of thought have arisen; antioxidants play a beneficial role in improving cancer treatment tolerance at normal and supplemented levels (reduces infections and less frequent delays in treatment) whereas the other school of thought is that antioxidants may interfere with the efficacy of certain cancer treatments.

From the literature review it can be concluded that cancer-induced antioxidant depletion may be associated with:

- Increased utilization by the tumor itself or the resulting oxidative stress.

- Chemotherapy/radiotherapy per se may induce oxidative stress and hence increase the utilization and need for antioxidants. 
Few studies exist for the investigation into the intake of antioxidants in children and adolescents with cancer. Parents frequently question the use of vitamin-mineral supplementation (VMS) during treatment especially additional antioxidants intake in the form of food or supplementation and general advice on providing foods with antioxidants is sought. Therefore such research would be invaluable in determining the trends of energy, protein and antioxidant intake in children and adolescents the categories of Solid tumours, Lymphomas and Leukaemia that will enable health care professionals to provide proactive and effective advice during treatment. 
CHAPTER 2: METHODOLOGY 


\subsection{STUDY OBJECTIVES}

\subsubsection{RESEARCH PROBLEM}

The adequacy of antioxidant consumption in children and adolescents with Solid tumours, Lymphomas and Leukaemics on treatment: an investigation into vitamin $A, E, C$, zinc and selenium consumption in paediatric patients that attended the East of England Primary Treatment Centre (Cambridge University Hospitals NHS Foundation Trust, England).

\subsubsection{RESEARCH AIM AND SPECIFIC OBJECTIVES}

The aim of the study was to investigate whether the paediatric patient with a Solid tumour, Lymphoma or Leukaemia were meeting their RNI for antioxidants (vitamin A, C, E, selenium and zinc) whilst undergoing cancer treatment. The specific objectives that were investigated were as follows (Figure 2.1):

a.) To determine the total daily antioxidant intake by means of a 4-day estimated food record (EFR

- primary research tool) and $24 \mathrm{hr}$ recalls (verification tool) as follows:

a Tube feeding with/without oral feeding and with/without VMS and/or antioxidant supplements.

口 Oral diet with and without VMS and/or antioxidant supplements.

b) To determine the following regarding antioxidant intake:

a Comparison with age appropriate RNl's (including the standard deviation of daily antioxidant intake from the RNI).

- Whether the fat-soluble antioxidants (vitamin A and E) are exceeding the Safe Upper Intake per day based on the Joint Food and Agricultural Organization of the United Nations and recommended by $\mathrm{DOH}$ (for further information see Addendum D). ${ }^{(16,54)}$

- The prevalence of VMS and/or antioxidant supplements use.

口 The types of VMS used.

c) Compare each child and adolescents daily total energy and protein intake to his/her age appropriate RNI. 


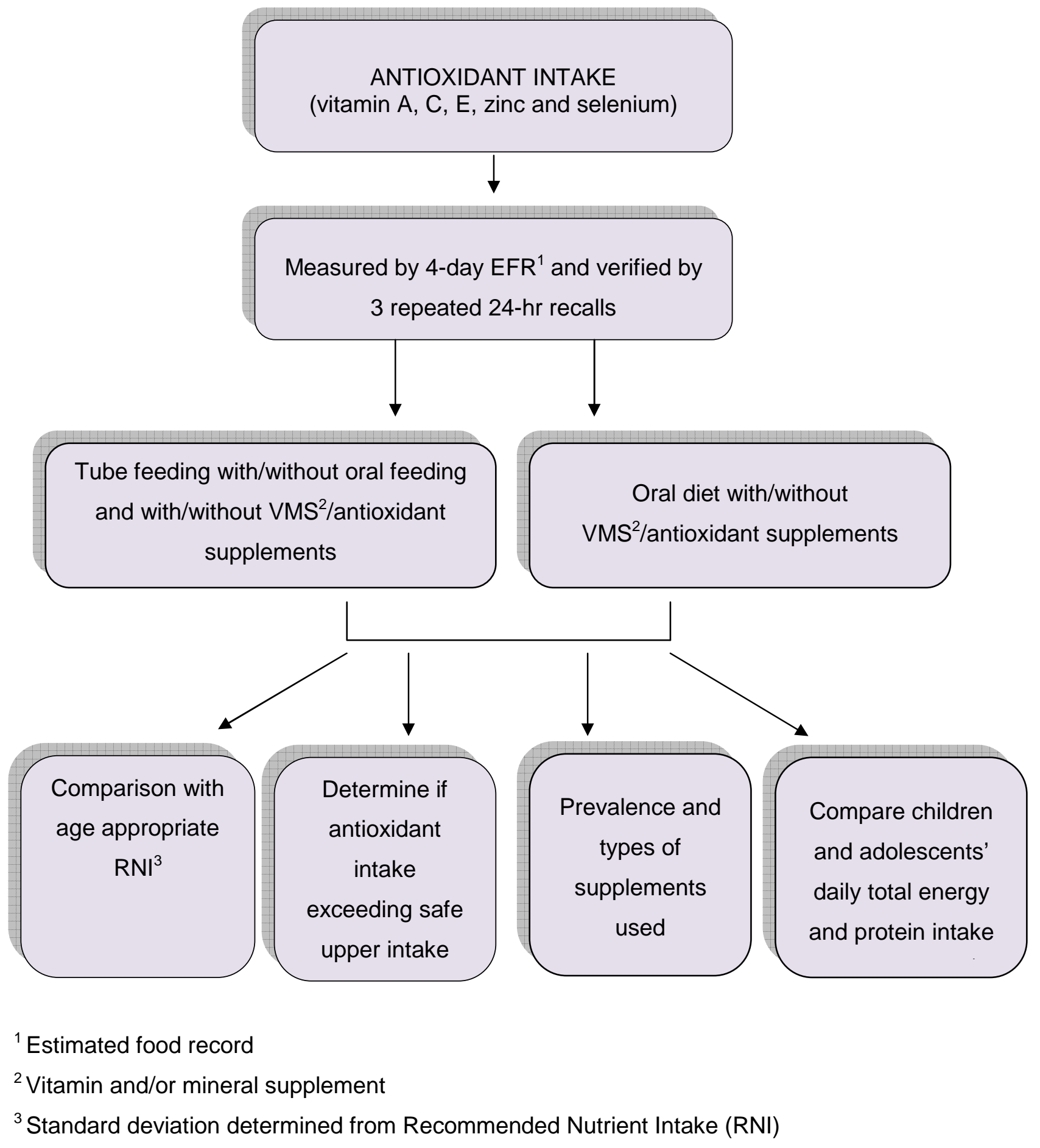

Figure 2.1 Diagrammatical representation of the specific objectives 


\subsection{STUDY DESIGN OVERVIEW}

The study was a single centre prospective study investigating the antioxidant intake of paediatric oncology patients who were undergoing treatment.

\subsubsection{STUDY POPULATION}

\subsubsection{SELECTION OF SAMPLE}

The study population included all children and adolescents living in the East Anglia area in England that were diagnosed with Solid tumours, Lymphomas or Leukaemia. The study population attended the East of England Primary Treatment Centre (Cambridge University Hospitals NHS Foundation Trust, England). The subjects were predominately English speaking, aged between 1 to 16 years and were sampled by means of convenience sampling. In the event that patients declined to continue in the study; further patients were recruited to ensure that a sample of greater than and equal to a total of 48 patients were recruited in the whole study.

\subsubsection{SAMPLE SIZE}

The sample size was calculated based on the 2006 Paediatric Haematology/Oncology Annual Report from Addenbrookes Hospital; Cambridge University Hospitals NHS Trust. The Paediatric Haematology/Oncology unit averaged 6 newly diagnosed children and adolescents with Lymphomas and Solid tumours per month and therefore a time period of between 6-8 months for data collection was set dependent on the numbers obtained in this time. Data collection commenced June 2008. The aim was to recruit about 48 children and adolescents, which equated to approximately half of the total population of Lymphomas and Solid tumours diagnosed at this unit per year. However, during the study the inclusion requirements were adjusted allowing for other types of cancer to be included due to slow patient recruitment. Data collection was estimated to take 5-7 months, however during the first 3 months; only 8 children and adolescents had been recruited in the Solid tumour and Lymphoma diagnosis group. Factors contributing to the slow uptake were the low frequency of admissions to hospital during the first month of data collection as well as parents' slow progress in returning food records even with frequent prompting. One further factor was the lower rate of diagnosis in comparison to 2006/2007, which could not be anticipated. The original motivation for the study was to focus on the Solid tumour and Lymphoma groups, as there was less evidence than that for leukaemia. Due to limited recruitment the study was expanded to incorporate the Leukaemia cancer group to ensure adequate recruitment within the allocated time frame. The recruitment criteria for the study were as follows: 


\section{Inclusion Criteria}

\ Children and adolescents (male and female)

- Receiving 'active' cancer treatment (chemotherapy and radiation therapy) at the Cambridge University Hospital NHS Trust. All Solid tumours, Lymphomas and Leukaemia types were included including children and adolescents with:

- Solid tumours: Brain, Wilms, Primitive Neuro-ectodermal tumour Rhabdomyo-, Osteo- and Ewings sarcoma, and Neuroblastoma

- Lymph cancer: Hodgkin, Non-Hodgkins and Burkitts lymphoma

- Acute lymphoblastic leukaemia

- Acute myeloid leukaemia

a Age 1-16 years. Adolescents above 16 years of age are treated under the Adult Oncology services.

a Parent/guardian and/or family member need to be literate in English to enable the completion of the research tools at home i.e. estimated food record.

\section{Exclusion criteria}

- Children and adolescents receiving palliative care, however those who were subsequently diagnosed as palliative after the data had already been collected were still included in the results.

a Any inpatients, as food records were required to be completed once the child and adolescent was discharged from the hospital. Periods of time spent in hospital were not reflective of a normal intake due to infections, chemotherapy and associated nausea/vomiting and diarrhoea or Neutropenic Enterocolitis.

- Children and adolescents on home parenteral nutrition.

- Breastfed infants and toddlers, as volumes of breast milk consumed cannot be measured.

a Less than 1 year of age. At this age it was difficult to determine intake of weaning foods due to messy mealtimes and reflux or vomiting of feeds upon burping of infant.

a No informed consent obtained.

The children and adolescents who took party in this study will be referred to as 'child and children' from this point forward.

\subsection{METHOD OF DATA COLLECTION}

The specialist oncology dietitians informed the researcher of the newly diagnosed children with Solid tumours, Lymphomas and Leukaemia upon verbal consent from the child/parent/guardian. 
The researcher made contact with the child/parent/guardian on the ward or outpatient clinic at Addenbrookes Hospital within 1 month of diagnosis. The information provided at the first consultation included an invitation letter (Addendum E) with a brief description of the study as well as information sheets for the following age categories: parents/guardian, less than 5 years, 6-10 years and 11-16 years (Addendum F). Parents/guardians were given 2 weeks to consider whether to give consent or not.

If the child/parent/guardian decided to participate in the study, the researcher arranged for written consent to be obtained. The original copy of the consent form was kept with the researcher in a file locked in the Nutrition and Dietetic Department, at Addenbrookes Hospital. A further copy of the consent form was also placed in the child's medical notes and the parent/guardian could also request a copy (Addendum G). Once consent was obtained the researcher provided oral and written information on the correct completion of the Estimated Food Record (EFR) (Addendum H), 24-hour (hr) recalls (Addendum I) and use of the food portion size photographs. The child's details were documented once parents of the child had consented to partake in the study. These details were logged into an excel spreadsheet as follows; hospital number, date of birth, diagnosis, start date, type of treatment, telephone number and if they decided to withdraw from study. Each child's hospital number was allocated an identification number to maintain confidentiality of child's data.

In the $2^{\text {nd }}$ week after discharge from hospital, the parent/guardian was contacted via telephone by the researcher to complete the 24-hr recalls (reference method) on alternate days i.e. on the Monday (for Sunday intake), Wednesday (for Tuesday intake), Friday (for Thursday intake), and Sunday (for Saturday intake). The parents were informed of the date on which the 24-hr recalls were to start. The EFR was completed the following week ( $3^{\text {rd }}$ week after discharge from hospital). By completing the 24-hr recalls the week before the EFR, it prevented parents from 'reading off' the EFR that they have just completed therefore improving the accuracy of the results. According to Gibson it is recommended practice to complete $24 \mathrm{hr}$ recalls on non-consecutive days (as was implemented in this study). ${ }^{(55)}$ The 24 -hr recalls and EFR were repeated 3 months later during treatment using the same sequence.

Each child received one 4-day EFR with a prepaid envelope at the first consultation and a further EFR was sent out 3 months later. The EFR was completed in the home environment, and not in the hospital setting (i.e. ward). This was due to the child's food and fluid intakes changing dramatically in admissions due to chemotherapy and/or radiotherapy and associated nausea/vomiting, diarrhoea, infections or neutropenic enterocolitis, therefore giving a skewed result. The child/parent was requested to return the EFR within 1 month of receiving it. If the EFR had not been returned within this period, the researcher called to remind the parent/guardian to return it. The first EFR served as the baseline measurement for total daily antioxidant intake. 
Adolescents were able to facilitate the completion of the EFR with supervised input from their parents, to prevent the incorrect completion. Parents/guardians were asked to provide a copy of the contents sheet or packaging of the VMS and/or antioxidant supplements used upon returning the EFR. The 24-hr recall method was used as the reference method to complement the EFR. A summary of the data collection process is provided in Figure 2.2.

The specialist oncology paediatric dietitians on the ward assessed the each child's nutritional status and provided appropriate advice on nutritional support and managing side effects of the treatment as per usual, without interference from the research dietitian. The nutritional support algorithm that was designed by these dietitians based on the available evidence for assessing nutritional risk, and stage at which to use a nutritional support was used in the usual way (Addendum J). 
Specialist Paediatric Oncology Dietitian's inform researcher of newly diagnosed patient with a Solid Tumour, Lymphoma or Leukaemia.

Researcher approaches patient and parent/guardian to partake in study on ward or outpatient paediatric clinic at Addenbrookes Hospital. This occurs within first month of diagnosis. Written and verbal information on study provided.

Consent obtained from child's/parent/guardian. Parent/guardian informed on the completion of EFR ${ }^{1}$ and telephone calls for $24-$ hr recalls.

$E F R^{1}$ given at first consultation and $2^{\text {nd }} E F R^{2}$ sent in post after 3 months.

Parent/guardian will be informed when to complete EFR ${ }^{1}$. EFR ${ }^{1}$ completed by parent/guardian for 4 consecutive days (Wednesday, Thursday, Friday, Saturday).

EFR's ${ }^{1}$ and 24-hr recalls analyzed using Standard Manual on Food Portions and Household Measures in the United Kingdom and Dietplan 6.3

${ }^{1}$ Estimated food record (EFR)

Figure 2.2 Diagrammatical representation of data collection 


\subsubsection{RESEARCH TOOLS}

\subsubsection{ESTIMATED FOOD RECORD}

No results were found upon extensive searching for a validated, 4-day EFR that specifically measured antioxidant intake in paediatrics. The researcher therefore developed a 4-day estimated food record for this purpose (Addendum H). The EFR was developed and adapted from a food record currently used in the Nutrition and Dietetic Department at Addenbrookes Hospital to suit the study's requirements. The EFR was reviewed by two external independent reviewers. The EFR was adjusted to elicit appropriate information about antioxidants from a paediatric population taking into account oral diet, tube feeds and the use of VMS supplements. The rationale for choosing this specific tool in this study population was due to:

- The traumatic experience of the diagnosis and treatment, a 4-day instead of a 7-day estimated food record as well as estimated food record in place of a weighted food record was chosen. The EFR would be less labour intensive and practical and was thought to be more suitable for this specific population and study. ${ }^{(55)}$

- Data from a multiple day food record being more representative of usual/habitual intake than single day data from a 24 -hr recall or 1 -day food record. ${ }^{(56,57)}$ If determining a dietary inadequacy or excess relative to a standard (i.e. RNI), then a single day for intake of an individual was not adequate in ensuring a reliable estimate of the distribution of habitual intake in between groups for e.g. for tube and non-tube fed children. Rutishauser and Black recommend that in determining distribution of habitual food intake in a group that at least 2 days of information from each individual is needed. ${ }^{(58)}$ Children's intake on cancer treatment varied considerably on a daily basis due to the treatment regimes and side effects thereof.

a The EFR not being dependent on memory as parents/guardians/children recorded foods and beverages at the same time of consumption. ${ }^{(56)}$

The EFR was completed over 4 consecutive days (i.e. Wednesday, Thursday, Friday, and Saturday) in the $3^{\text {rd }}$ week after discharge from hospital and again in the $3^{\text {rd }}$ month of diagnosis. In the EFR, days were truncated into six eating occasions, namely breakfast, lunch, dinner and snacks (divided into morning, afternoon and evening snacks). Information on the type (including brand names) and amount of food consumed was collected through an open entry format. An example of a 1-day food intake was included to demonstrate the accurate completion of the EFR. Household measures such as cups, tablespoons, and teaspoons or measurements made with a ruler were used to quantify portion size. Items such as eggs, fruit i.e. apples, bananas or $330 \mathrm{ml}$ cans of fizzy drink were thought of as units and simply counted. A checklist was included at the end of the food record booklet to help parents/guardians to check that they had completed an accurate record. Parents/guardians were asked to send the outer packaging, photocopy or written 
copy of any vitamin-mineral preparations used. Parents/guardians were able to document all tube/sip feeds and other supplements and were prompted to specify the type of feed, volume, feeding hours as well as the preparation method of feed (powdered feed and concentrations). For children greater than 1 year, all formula, feeds, with the exact volumes needed to be documented. The EFR was designed to elicit information pertaining to tube/sip feeds and other supplements and pump feeding i.e. type of feed, volume, hours, and preparation method. Upon receiving the EFR if there were any parts to clarify the researcher contacted the parents/guardian. After completion of the food records, these were processed by the researcher, into food gram quantities based on the Standard Manual on Food Portions and Household Measures in the UK. ${ }^{(59)}$

\subsubsection{24-HOUR RECALL}

The 24-hr recall method was introduced as a second dietary intake measurement (test method). This method assessed the actual intake of individuals in the study. A single 24-hr recall however was not sufficient to describe an individual's usual intake of food and nutrients. Therefore to determine the percentage of the population 'at risk' of inadequate nutrient intakes, estimates of the usual intakes of the subjects was required. This, in turn, required that the food consumption of subjects was measured over more than 1 non-consecutive day. According to Gibson to achieve a 'level 2' objective in determining risk, at least two independent measurements of food intake should have been obtained on at least a representative sub-sample of individuals in the study and on nonconsecutive days. ${ }^{(55)}$ The sub-sample needed to consist of 30 to 40 individuals who represented the age range of the sample. ${ }^{(55)}$ Once a series of replicated observations on at least 30 individuals were obtained, an adjustment could be made to the observed distribution of intakes to remove the variability introduced by day-to-day variation in nutrient intakes within an individual. The adjusted distribution of 'usual' nutrient intakes could then be used to predict the proportion of the population at risk of nutrient inadequacy using either the full probability approach or the RNI. ${ }^{(55)}$

A standardized 24-hr recall, sourced from Weiner and Lourie cited by Gibson, ${ }^{(55)}$ was used on the sample population to test whether the EFR was eliciting adequate information with regard to total daily antioxidant intake. The researcher verified the accuracy of the EFR by performing three 24hrrecalls by telephone the week before the EFR was completed ( $2^{\text {nd }}$ week after discharge from hospital). The 24-hr recall was performed on Monday (for Sunday intake), Wednesday (for Tuesday intake), Friday (for Thursday intake) and Sunday (for Saturday intake) and determined the child's past 24-hr intake of antioxidants. The 24-hr recall was performed on both the EFRs issued. The researcher was required to ask appropriate questions on the intake of foods and drinks over the past 24 hours using open-ended questions with no leading questions or judgemental comments. Telephone 24 -hr recalls that were well designed and carefully administered appeared to be a promising and acceptable method of obtaining dietary information as described by 
Gibson. ${ }^{(55)}$ Due to the geographical location of the children it was not feasible to visit the child's home to conduct the $24 \mathrm{hr}$ recall.

\subsubsection{PILOT STUDY}

The pilot study was tested on 4 children upon consent to the study to determine the face and content validity of the EFR. This process established whether meanings of the food names, portion size descriptions, volume and concentration of tube feeds and VMS were clearly documented in the EFR by the parent/guardian. It facilitated the identification of whether the instructions on how to complete the EFR and the EFR itself were unambiguous. Content validity was determined by requesting two specialist/expert paediatric Dietitians (namely $\operatorname{Dr}$ Anita Macdonald, Dietetic Manager at Birmingham Children's Hospital, England, and Vanessa Shaw, Dietetic Manager at Great Ormond Street Hospital, England) to critique the EFR. Face validity was determined in the pilot study. The 24-hr recall was used as a reference method to complement the EFR and test whether the EFR was eliciting the correct information with regard to total daily antioxidant intake (Addendum K). Adjustments were made as necessary to the EFR based on the results from the pilot study.

\subsection{MEASUREMENT OF MALNUTRITION}

The tool used to measure acute malnutrition in this study was that of weight-for-age $z$ scores. ${ }^{(60)}$ These scores were compared to the World Health Organization definitions of malnutrition, ${ }^{(43)}$ which uses a z-score cut-off point of <-2 SD to classify low weight-for-age, low height-for-age and low weight-for-height as moderate under-nutrition and severe under-nutrition as <-3 SD. Although a hospital protocol exists for routine growth measurements (i.e. weight, height and head circumference), not all of these are routinely measured by staff. In particular height is frequently not measured in children in the 1-3 year age group, those with vincristine induced neuropathy, those weak from ill health and in many children who attend weekly outpatient clinics; height isn't measured weekly. Weight is seen more as a priority in the outpatient clinic to determine drug doses for chemotherapy. Therefore only weight was used in the study.

\subsection{DATA ANALYSIS}

Upon receiving the completed EFR and 24-hr recall data, it was manually analysed by the researcher into food gram quantities based on the Standard Manual on Food Portions and Household Measures in the United Kingdom. ${ }^{(59)}$ Subsequent to this the initial analysis for the total intakes of antioxidants, total energy and protein were performed using the Diet Plan 6.3 programme (Forrestfield Software Limited, Horsham, UK) (Table 2.1). 
Table 2.1 Summary of measurements for antioxidants, energy and protein used in analysis

\begin{tabular}{|c|c|}
\hline Vitamin/mineral & Measurement \\
\hline Vitamin A & milligram $(\mathrm{mg})$ a - tocopherol equivalents \\
\hline Vitamin E & milligrams $(\mathrm{mg})$ \\
\hline Vitamin C & milligrams $(\mathrm{mg}$ \\
\hline Selenium & microgram $(\mathrm{ug})$ \\
\hline Zinc & milligram $(\mathrm{mg})$ \\
\hline Energy & kilocalories $(\mathrm{kcal})$ \\
\hline Protein & gram $(\mathrm{g})$ \\
\hline
\end{tabular}

Further analysis required the use of the SPSS 16 statistical software (SPSS Science, Apache Software Foundation, Chicago, IL, USA). The children's mode of feeding was divided into the following categories with abbreviations (Table 2.2). These dietary categories below were used to analyse the data in the study.

Table 2.2 Mode of feeding categories and abbreviations used in study

\begin{tabular}{|c|c|}
\hline Mode of feeding & Abbreviation \\
\hline Diet alone & Diet alone \\
\hline $\begin{array}{c}\text { Diet \& food supplement (incl. modular } \\
\text { supplements and nutritionally complete } \\
\text { sip feeds) }\end{array}$ & Diet + FS \\
\hline $\begin{array}{c}\text { Diet \& tube feeds } \\
\text { Diet \& multi-vitamin-mineral } \\
\text { supplementation }\end{array}$ & Diet + tube \\
\hline Diet \& multi-vitamin-mineral \& food \\
supplement
\end{tabular}

For data analysis purposes and to meet the study's objectives (ascertain the intake of children on diet + tube) the researcher grouped the diet + FS and diet + tube categories together, however only the children (diet + FS category) who were taking nutritionally complete sip feed supplements were included. These sip feeds were comparable in composition to tube feeds and could be used as tube feeds. The sip feeds included products such as Fortini (Nutricia), Paediasure (Abbott) and Paediasure Plus (Abbott) and Frebini (Fresenius) (1 kcal and 1.5kcal). The children in the diet + FS category that were on modular supplements i.e. providing singular entities of nutrition (either fat or 
protein or carbohydrate) were excluded from data analysis. These modular supplements included products such as Calogen (SHS) and Maxijul powder (SHS). The similar principle was used for the diet + FS + VMS category. The children in this latter category were included both into the diet + VMS categories. The above grouping of categories was also to ensure that the primary categories had sufficient numbers for statistical purposes.

The child's antioxidant intakes were compared to both the LRNI and RNI to determine adequacy. The RNI values are divided into the following age groups i.e. 1-3, 4-6, 7-10, 11-14, and 15-18 years of age, which were also used for the analysis of this dietary data. In the case whereby children fell between the above age group ranges, their antioxidant intake was compared to the age group rounded to the closest ten-decimal. Similarly the protein and energy intake was compared to the EAR (Addendum $\mathrm{C}$ ). The adequacy of intake was measured in percentage by measuring the actual intake to the RNI requirement for the age and gender of that child. Dietary adequacy was assumed at $100 \%$ and above of the RNI for the antioxidant. As it was possible for children to exceed this threshold a further parameter of greater than and equal to $200 \%$ was set. Similarly the actual intakes were compared to the LRNI. If the child's intake was below the LRNI, then it was assumed that the intake was inadequate and that the child may be deficient in that vitamin or mineral. If a child's habitual intake was less than and below the LRNI it was likely that the individual would not be consuming enough of the nutrient to maintain appropriate parameters of nutritional status for that nutrient, and further investigations, including biological measures may be appropriate. ${ }^{(16)}$

The Chi-square test was used to test for the differences between the three feeding modes intakes of antioxidants, energy and protein in the $1^{\text {st }}$ and $3^{\text {rd }}$ month (significance level at $p<0.05$ ). To measure significant changes in the antioxidant, protein and energy intake between month 1 and month 3, the Fishers Exact Test was used (significance level at $p<0.05$ ). The Shapiro-Wilk formula was used to assess the normality of the distribution of data between the EFR and the corresponding 24-hr recall. Both the Shapiro-Wilk and Fishers Exact Test was used due to the smaller analysis categories. Bivariate correlation (Spearman and Pearson) were used to determine the strength and direction of the relationship between the EFR and corresponding 24-hr recall. In addition, t-tests were used to compare the mean score of nutrient intakes, based on the EFR and 24-hr recall, between the two groups.

Descriptive data was presented as means, medians and standard deviations. Results were deemed significant if the $\mathrm{p}$-value was less than 0.05. The deviation from the daily RNI was determined for each child making use of diet, diet with tube feeding and diet with VMS and was presented in percentage deviation. The antioxidant, energy and protein intake for the EFR in the first month was compared to that obtained in the $3^{\text {rd }}$ month to determine changes in the intake of 
energy, protein, and antioxidants as treatment progressed. The percentage of children meeting their RNI requirement as well as those consuming double this requirement for antioxidants, EAR protein and energy were documented. The vitamin and/or mineral supplements were divided into two main groups namely those providing a full complement of vitamins and minerals and those that primarily provided vitamins.

Each child's nutritional risk which was based on their type and stage of cancer was determined by the criteria set out by Rickard et al. ${ }^{(41)}$ and cited by Ward (Table 1.2). Acute malnutrition was measured by means of documenting each child's weight at the $1^{\text {st }}$ and $3^{\text {rd }}$ month. This data was then entered into the Anthro. Epi Info ${ }^{T M}$ Version 3.3.2 (CDC, USA) programme which determined zscores for weight-for-age. To prevent the use of two data analysis programmes the Anthro. Epi Info $^{\mathrm{TM}}$ programme was used instead of the WHO database. The rationale for this was that the Anthro Epi Info ${ }^{\mathrm{TM}}$ programme was able to determine the z-scores of the study population that included children of 1-16 years of age, whereas the WHO anthropometry database only measured z-scores of children less than 5 years of age. The weight-for-age z-scores as well as the mean and standard deviation (SD) z-scores were then assessed against the World Health Organization Global Database on Child Growth and Malnutrition. ${ }^{(43)}$ The children nutritional risk was assessed according to associated types of childhood cancers that were set out in Table 1.2.

\subsection{ETHICS APPROVAL}

The NHS as well as Stellenbosch University required ethical approval for this study. Approval was therefore obtained from the Health Research Committee of Stellenbosch University (South Africa) (Ethics Reference Code N08/04/094) (Addendum L) and Hertfordshire Research Ethics Committee (England) (Ethics Reference Code 08/H0311/53) and R \& D Department at Addenbrookes Hospital (Addendum M).

Parents/guardians and children were provided with all appropriate documentation to consider the study as outlined in section 2.3. It was required that prior to obtaining consent that parents were informed of the following:

a Patient confidentiality would be adhered to at all times.

a Withdrawal from the study was allowed at any point in time, and this wouldn't affect further treatment plan. It was agreed upon ethics approval that if data was collected and the child withdrew that any valuable data that could contribute to the antioxidant intake data would be retained and used towards the study. Children/parents/guardians would be made aware that anonymous data would be sent to South Africa for consultation by the statistician. 
- If the intakes of antioxidants, energy and protein were deficient that the child/parent/guardian would be informed and be provided with appropriate advice to correct this.

The parent/guardian signed the consent form for the child or adolescent partaking less than 16 years of age. If a child was over 7 years of age they were allowed to sign the ascent form or the consent form for the parent. This was stipulated by the local Health Trust specifications. The original copy of the consent form was kept with the researcher in a file locked in the Nutrition and Dietetic Department, at Addenbrookes Hospital. A copy was placed in the child's medical notes and the parent/guardian was also provided with a copy (Addendum G). Upon study completion the data will be stored for 5 years by the Study Supervisor and Paediatric Haematology Department of Addenbrookes Hospital for 15 years as required by National Ethics Research Service (England). 


\section{CHAPTER 3 RESULTS}




\subsection{DESCRIPTION OF STUDY}

\subsubsection{MAIN STUDY RESULTS}

\subsubsection{PATIENT DEMOGRAPHICS}

The collated data of forty-two children (male $n=20$; female $n=22$ ) was used for analysis in this study (Table 3.1). The mean age was 7 years 6 months (SD 4.8), with an age range of 12 months to 15.5 years. Fifty two children were recruited to this study over a period of 1 year and 8 months; however 10 children were not included in the data analysis for the following reasons; 4 (8\%) withdrew from study; 1 (2\%) was not discharged from hospital during treatment; 1 (2\%) transferred to an out of area hospital; 4 (8\%) consented to study, but did not respond to requests for data. Of the 42 children's data that was analysed, a large proportion returned their EFR's in the $1^{\text {st }}$ month's collection of data ( $n=30 ; 71 \%)$. However the return rate of EFR's in the $3^{\text {rd }}$ month was less than the $1^{\text {st }}$ month ( $\left.\mathrm{n}=22 ; 52 \%\right)$. Reasons for this as reported by parents were: EFR's were lost in the post and that parents did not have time to complete the EFR due to busy treatment schedules and home life. The demographics of the study population are outlined in Table 3.1. Children were categorised into the following diagnosis groups: Leukaemia $(n=14 ; 33 \%)$, Lymphoma $(n=10 ; 24 \%)$, and Solid tumours $(n=18 ; 43 \%)$.

Table 3.1: Demographic data and characteristics of the children recruited to the study

\begin{tabular}{|c|c|c|c|}
\hline & All & Male & Female \\
\hline Number of children [n;(\%)] & 42 & $20(48 \%)$ & $22(52 \%)$ \\
\hline Age groups [n;(\%)] & $13(31 \%)$ & $4(10 \%)$ & $9(21 \%)$ \\
$1-3$ years & $9(21 \%)$ & $6(14 \%)$ & $3(7 \%)$ \\
$4-6 y e a r s$ & $6(15 \%)$ & $4(10 \%)$ & $2(5 \%)$ \\
$7-10 y e a r s$ & $13(31 \%)$ & $6(14 \%)$ & $7(17 \%)$ \\
$11-14$ years & $1(2 \%)$ & $0(0 \%)$ & $1(2 \%)$ \\
$15-18 y e a r s$ & 7 years 6 months & 7 years 7 months & 7 years 2 months \\
Mean age of children & & & SD 5.39 \\
Standard deviation & SD 4.8 & SD 4.28 & $1-15.5$ years \\
Age Range & $1-15.5$ years & $1.6-14.5$ years & \\
\end{tabular}

Therapy modalities were categorised into chemotherapy and combination chemo- and radiotherapy. Twenty eight $(67 \%)$ of the children underwent chemotherapy and fourteen (33\%) a combination of therapies. For data analysis purposes and to meet the study objectives the researcher grouped the diet $+F S\left(1^{\text {st }}\right.$ month $n=11 ; 3^{\text {rd }}$ month $\left.n=5\right)$ and diet + tube categories $\left(1^{\text {st }}\right.$ 
month $n=2 ; 3^{\text {rd }}$ month $n=3$ ) together. The child's mode of feeding as categorised for this study is represented for the $1^{\text {st }}$ month in Table 3.2 and $3^{\text {rd }}$ month in Table 3.3.

Table 3.2 Mode of feeding for estimated food record and 24-hr recall ( $1^{\text {st }}$ month)

\begin{tabular}{|l|c|c|c|c|}
\hline \multicolumn{1}{|c|}{ Mode of feeding } & $\begin{array}{c}\text { Nr. completed } \\
\text { EFR }\end{array}$ & $\begin{array}{c}\text { \% from } \\
\text { EFR }\end{array}$ & $\begin{array}{c}\text { Nr. completed } \\
\text { 24-hr recall }\end{array}$ & $\begin{array}{c}\text { \% from } \\
\text { 24-hr recall }\end{array}$ \\
\hline Diet only & 11 & 26 & 15 & 36 \\
\hline Diet + tube & 11 & 26 & 11 & 26 \\
\hline Diet + FS & 3 & 7 & 5 & 12 \\
\hline Diet + VMS & 6 & 14 & 9 & 21 \\
\hline Diet + FS + VMS & 2 & 5 & 2 & 5 \\
\hline Data not completed & 9 & 21 & 0 & 0 \\
\hline
\end{tabular}

EFR $=$ estimated food record

$\mathrm{VMS}=$ multi - vitamin-mineral supplement
FS = food supplement

Data not completed $=$ child $/$ parent did not return data

Table 3.3 Mode of feeding for estimated food record and 24-hr recall ( $3^{\text {rd }}$ month)

\begin{tabular}{|l|c|c|c|c|}
\hline \multicolumn{1}{|c|}{ Mode of feeding } & $\begin{array}{c}\text { Nr. completed } \\
\text { EFR }\end{array}$ & $\begin{array}{c}\text { \% from } \\
\text { EFR }\end{array}$ & $\begin{array}{c}\text { Nr completed } \\
\text { 24-hr recall }\end{array}$ & $\begin{array}{c}\text { \% from } \\
\text { 24-hr recall }\end{array}$ \\
\hline Diet only & 10 & 24 & 13 & 31 \\
\hline Diet + tube & 5 & 12 & 10 & 24 \\
\hline Diet + FS & 3 & 7 & 3 & 7 \\
\hline Diet + VMS & 4 & 9 & 5 & 12 \\
\hline Diet + FS + VMS & 0 & 0 & 1 & 2 \\
\hline Data not completed & 20 & 48 & 10 & 24 \\
\hline
\end{tabular}

EFR $=$ estimated food record

VMS = multi - vitamin-mineral supplement
FS = food supplement

Data not completed $=$ child/parent did not return data 


\subsubsection{NUTRITIONAL STATUS}

Each child's nutritional risk was determined by assessing their type and stage of cancer as set out by the criteria by Rickard et al. ${ }^{(41)}$ and cited by Ward (Table 1.2). ${ }^{(42)}$ The latter nutritional risk was summarised in Table 3.4 and showed that $95 \%(n=40)$ of the children were seen as at high nutritional risk and $5 \%(n=2)$ at low risk.

Malnutrition was assessed using the weight-for-age scores and comparing it to the criteria set out by the WHO for malnutrition, as described in the methodology. ${ }^{(43)}$ Malnutrition as determined with this methodology is presented in Figure 3.1 for the $1^{\text {st }}$ and $3^{\text {rd }}$ month. In the $1^{\text {st }}$ and $3^{\text {rd }}$ month, 39 of the children had a weight and a height (when available) documented. A mean z-score for the study population was calculated at the $1^{\text {st }}(-0.22)$ and $3^{\text {rd }}(-0.34)$ month. This indicated that the study population on the whole were well-nourished. The WHO malnutrition criteria states that if the mean score is significantly lower than zero it suggests that most of the individuals in the population have been affected by malnutrition. Ninety five percent $(n=37)$ of the children $z$-scores for weight-for-age were within the normal range in the $1^{\text {st }}$ month and $85 \%(n=33)$ in the $3^{\text {rd }}$ month. In the $1^{\text {st }}$ month, $5 \%(n=2)$ of the children achieved a $z$-score of $<-2$ and $10 \%(n=4)$ in the $3^{\text {rd }}$ month (both months depicting moderate malnutrition). There was no statistical difference seen between the number of children presenting with moderate malnutrition between the $1^{\text {st }}$ and $3^{\text {rd }}$ month $(\mathrm{p}=0.67$; Fishers Exact Test). In the $1^{\text {st }}$ and $3^{\text {rd }}$ month the Solid tumour and Leukaemia group each had $1(3 \%)$ child with a $z$-score of $<-2$ and likewise in the $3^{\text {rd }}$ month. The lymphoma group only presented with 1 $(3 \%)$ child in the $3^{\text {rd }}$ month with a z-score of $<-2$. Children in the Leukaemia group were the only to present in the overweight $(n=1 ; 3 \%)$ and obese $(n=3 ; 3 \%)$ category in both the $1^{\text {st }}$ and $3^{\text {rd }}$ month. 
Table 3.4 Summary of types of childhood cancers associated with nutritional risk based on guidance provided by Rickard et al. ${ }^{(41,42)}$

\begin{tabular}{|c|c|c|c|c|c|c|}
\hline \multirow[b]{2}{*}{ Diagnosis } & \multicolumn{2}{|c|}{ Diagnosis } & \multicolumn{4}{|c|}{ Nutritional Risk $^{(41,42)}$} \\
\hline & Frequency & $\%$ & $\begin{array}{c}\text { High } \\
\text { risk }\end{array}$ & $\%$ & $\begin{array}{l}\text { Low } \\
\text { Risk }\end{array}$ & $\%$ \\
\hline Acute promyelocytic leukaemia & 1 & 2.4 & $\sqrt{ }$ & & & \\
\hline $\begin{array}{l}\text { Acute lymphoblastic leukaemia } \\
(\text { Reg A) }\end{array}$ & 1 & 2.4 & & & $\sqrt{ }$ & \\
\hline $\begin{array}{l}\text { Acute lymphoblastic leukaemia } \\
\text { (Reg B) }\end{array}$ & 11 & 26.2 & $\sqrt{ }$ & & & \\
\hline $\begin{array}{l}\text { B - cell non hodgkins } \\
\text { lymphoma }\end{array}$ & 4 & 9.5 & $\sqrt{ }$ & & & \\
\hline Burkitts lymphoma & 2 & 4.8 & $\sqrt{ }$ & & & \\
\hline Ewings sarcoma & 1 & 2.4 & $\sqrt{ }$ & & & \\
\hline $\begin{array}{l}\text { Germ cell tumour and } \\
\text { metastasis }\end{array}$ & 1 & 2.4 & $\sqrt{ }$ & & & \\
\hline Medulloblastoma & 2 & 4.8 & $\sqrt{ }$ & & & \\
\hline $\begin{array}{l}\text { Medulloblastoma and } \\
\text { metastasis }\end{array}$ & 1 & 2.4 & $\sqrt{ }$ & & & \\
\hline Neuroblastoma (stage III) & 1 & 2.4 & $\sqrt{ }$ & & & \\
\hline Neuroblastoma (Stage IV) & 2 & 4.8 & $\sqrt{ }$ & & & \\
\hline Osteosarcoma & 1 & 2.4 & $\sqrt{ }$ & & & \\
\hline Osteosarcoma and metastasis & 1 & 2.4 & $\sqrt{ }$ & & & \\
\hline Relapse wilms tumour & 1 & 2.4 & $\sqrt{ }$ & & & \\
\hline Rhabdomyosarcoma & 2 & 4.8 & $\sqrt{ }$ & & & \\
\hline $\begin{array}{l}\text { Rhabdomyosarcoma and } \\
\text { metastasis }\end{array}$ & 1 & 2.4 & $\sqrt{ }$ & & & \\
\hline $\begin{array}{l}\text { T - cell lymphoblastic } \\
\text { leukaemia }\end{array}$ & 1 & 2.4 & $\sqrt{ }$ & & & \\
\hline $\begin{array}{l}\text { T - cell lymphoblastic } \\
\text { lymphoma }\end{array}$ & 1 & 2.4 & $\sqrt{ }$ & & & \\
\hline $\begin{array}{l}\text { T - cell non hodgkins } \\
\text { lymphoma }\end{array}$ & 3 & 7.1 & $\sqrt{ }$ & & & \\
\hline Unilateral retinoblastoma & 1 & 2.4 & & & $\sqrt{ }$ & \\
\hline Wilms tumour (Stage III) & 2 & 4.8 & $\sqrt{ }$ & & & \\
\hline Wilms tumour (Stage IV) & 1 & 2.4 & $\sqrt{ }$ & & & \\
\hline Total & 42 & 100.0 & 40 & $95 \%$ & 2 & $5 \%$ \\
\hline
\end{tabular}




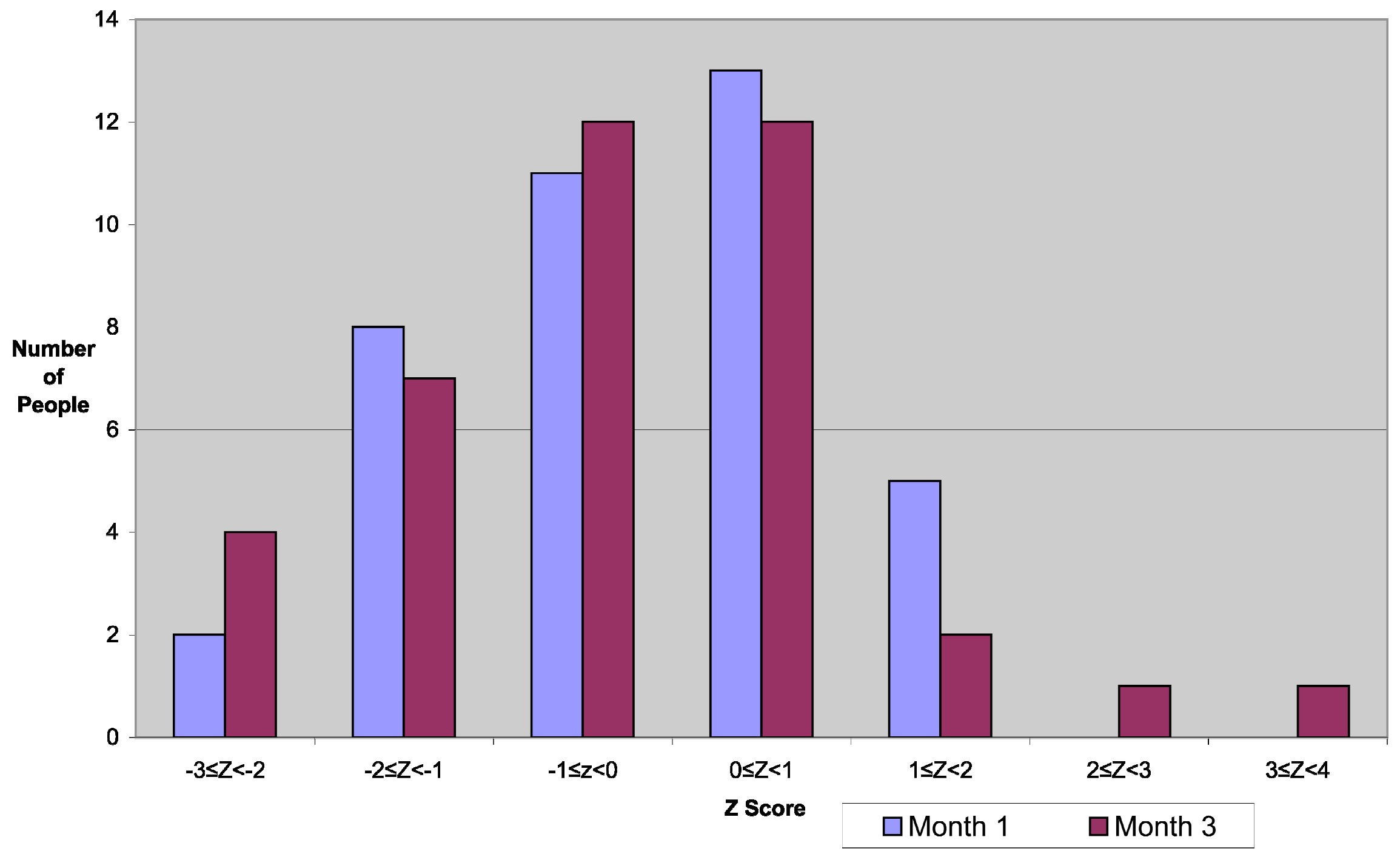

Figure 3.1 Grouping of $z$-scores for weight-for-age at initial assessment ( $1^{\text {st }}$ month) and follow up ( $3^{\text {rd }}$ month) 


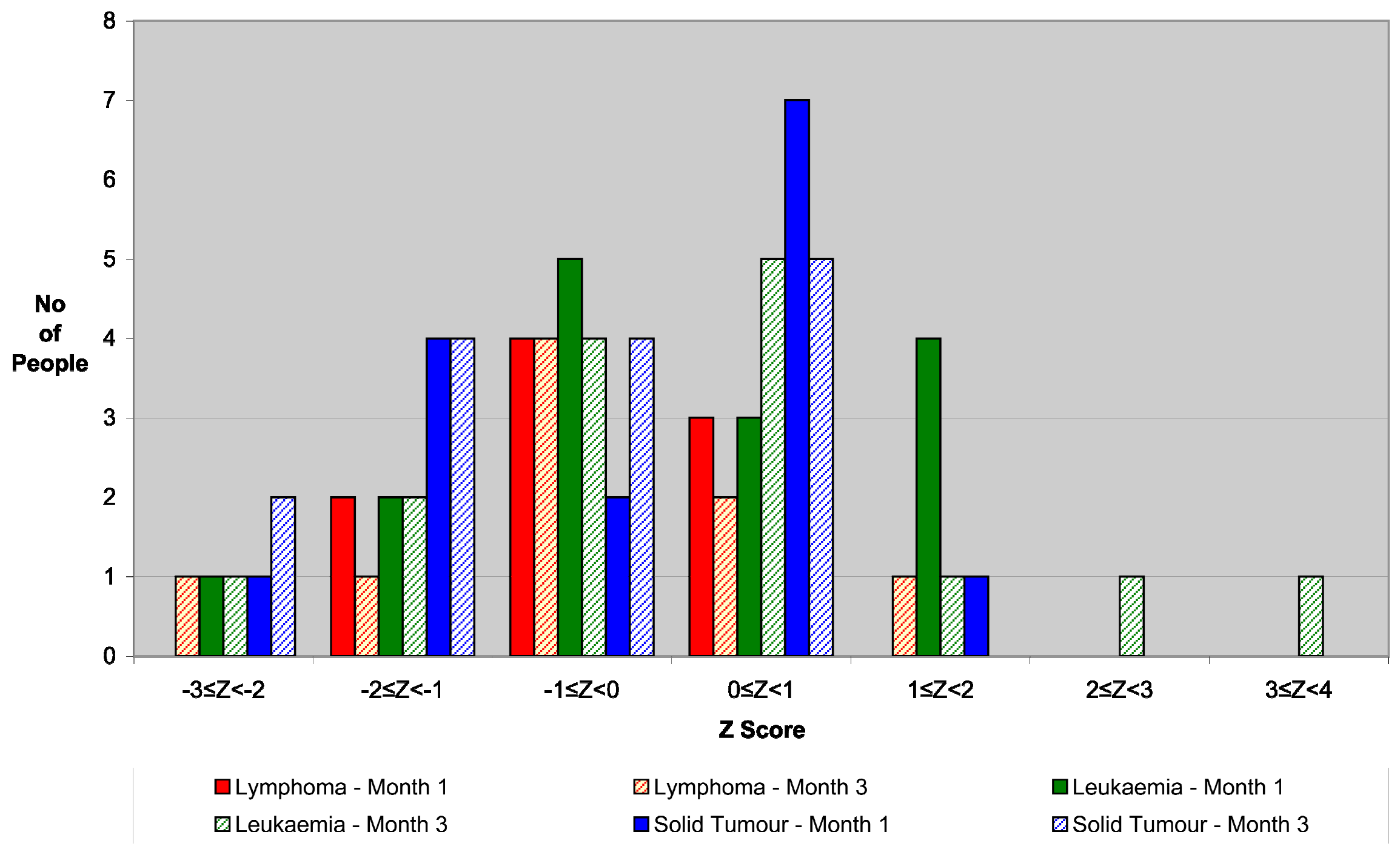

Figure 3.2 Malnutrition z-scores for children with Solid tumours, Lymphomas and Leukaemia at initial assessment ( $1^{\text {st }}$ month) and follow up ( $3^{\text {rd }}$ month) 


\subsubsection{VALIDITY OF DIETARY INTAKE METHODS}

\subsection{CORRELATION OF DIETARY INTAKE TOOLS FOR ANTIOXIDANT INTAKE}

The repeated 24-hr recalls were used to correlate against the EFR to determine if the EFR was eliciting accurate information. The following vitamin and mineral intakes from the EFR and 24-hr recall correlated highly in the $1^{\text {st }}$ month (EFR1); vitamin $A$ (diet alone; $p=0.00 ; r=0.70$ ), vitamin $C$ (diet alone; $p=0.00 ; r=0.56$ ), vitamin $E$ (diet alone; $p=0.00 ; r=0.54$ ), selenium (diet alone; $p=0.00 ; r$ $=0.64$ ) and zinc (diet alone; $p=0.00 ; r=0.81$ ). In the $3^{\text {rd }}$ month (EFR") the following correlated highly; vitamin $A$ (diet alone; $p=0.00 ; r=0.70$ ), vitamin $C$ (diet alone; $p=<0.05 ; r=0.72$ ), vitamin $E$ (diet alone; $p=0.05 ; r=0.45$ ), and selenium (diet alone; $p=0.00 ; r=0.61$ ) (Table 5). Therefore for all the antioxidants in the diet alone category significant correlations were seen between the EFR and 24-hr recall. There were too few children in the category of diet + VMS ( $n=81^{\text {st }}$ month; $n=43^{\text {rd }}$ month) to reach statistical significance or meaningful interpretation and no correlation was seen for the diet + tube category ( $n=13,1^{\text {st }}$ month; $n=8,3^{\text {rd }}$ month). On closer inspection it was found that parents varied tube feed intake significantly from day to day. This was highly dependent on their child's toleration of oral intake and/or tube feeds during and post chemotherapy and radiotherapy sessions. Flexible tube feeding regimes were provided by the Dietitian to accommodate for the child's oral intake (retain normality of eating patterns), the need for additional top-ups of feed or weaning down of feed to improve tolerance. These factors would explain the poorer correlation in the diet + tube category. As the EFR and the repeated 24-hr recall were highly correlated for the majority of categories for protein and energy with significant numbers of children and as it represented four days of continuous dietary intake instead of non-consecutive days, further analysis was based on the EFR. 
Table 3.5: Correlation of the estimated food record and 24-hr recalls for mode of feeding and Antioxidants ( $1^{\text {st }}$ and $3^{\text {rd }}$ month)

\begin{tabular}{|c|c|c|c|c|}
\hline Antioxidants & $r$ - value & $\begin{array}{c}\text { Strength of relationship } \\
\text { Small }(r=0.10-0.29) \\
\text { Medium }(r=0.30-0.49) \\
\text { Large }(r=0.50-1.0)\end{array}$ & p- value & Significant \\
\hline \multirow{2}{*}{\multicolumn{5}{|c|}{$\begin{array}{c}\text { Vitamin A } \\
\text { EFR } 1^{1} \& 24-h r \text { recall } 1\end{array}$}} \\
\hline & & & & \\
\hline Diet alone & 0.70 & large & 0.00 & $\Delta$ \\
\hline Diet + tube & -0.07 & small & 0.83 & \\
\hline Diet + VMS ${ }^{2}$ & 0.70 & large & 0.19 & \\
\hline \multicolumn{5}{|l|}{ EFR $2^{1} \& 24-h r$ recall 2} \\
\hline Diet alone & 0.70 & large & 0.00 & * \\
\hline Diet + tube & 0.61 & large & 0.15 & \\
\hline Diet + VMS ${ }^{2}$ & 0.50 & large & 0.67 & \\
\hline \multicolumn{5}{|l|}{$\begin{array}{c}\text { Vitamin C } \\
\text { EFR } 1^{1} \& 24-\mathrm{hr} \text { recall } 1\end{array}$} \\
\hline Diet alone & 0.56 & large & 0.00 & * \\
\hline Diet + tube & 0.65 & large & 0.08 & \\
\hline Diet $+\mathrm{VMS}^{2}$ & 0.00 & - & 1 & $\sim$ \\
\hline \multicolumn{5}{|l|}{ EFR $2^{1} \& 24-h r$ recall 2} \\
\hline Diet alone & 0.72 & large & 0.00 & * \\
\hline Diet + tube & 0.38 & medium & 0.35 & \\
\hline Diet + VMS ${ }^{2}$ & 0.50 & large & 0.67 & \\
\hline \multicolumn{5}{|l|}{ Vitamin E } \\
\hline EFR $1^{1} \& 24$-hr recall 1 & & & & \\
\hline Diet alone & 0.54 & large & 0.00 & * \\
\hline Diet + tube & 0.39 & medium & 0.38 & \\
\hline Diet + VMS ${ }^{2}$ & 1 & large & -0.99 & \\
\hline \multicolumn{5}{|l|}{ EFR $2^{1} \& 24-h r$ recall 2} \\
\hline Diet alone & 0.45 & medium & 0.05 & * \\
\hline Diet + tube & 0.50 & large & 0.17 & \\
\hline Diet $+\mathrm{VMS}^{2}$ & 1 & large & -0.99 & \\
\hline \multicolumn{5}{|l|}{ Selenium } \\
\hline \multicolumn{5}{|l|}{ EFR $1^{1} \& 24-h r$ recall 1} \\
\hline Diet alone & 0.64 & large & 0.00 & * \\
\hline Diet + tube & 0.10 & small & 0.80 & \\
\hline Diet $+\mathrm{VMS}^{2}$ & 1 & large & -0.99 & \\
\hline \multicolumn{5}{|l|}{ EFR $2^{1} \& 24-h r$ recall 2} \\
\hline Diet alone & 0.61 & large & 0.00 & * \\
\hline Diet + tube & -0.02 & small & 0.96 & \\
\hline Diet + VMS $^{2}$ & 0.50 & large & 0.67 & \\
\hline
\end{tabular}




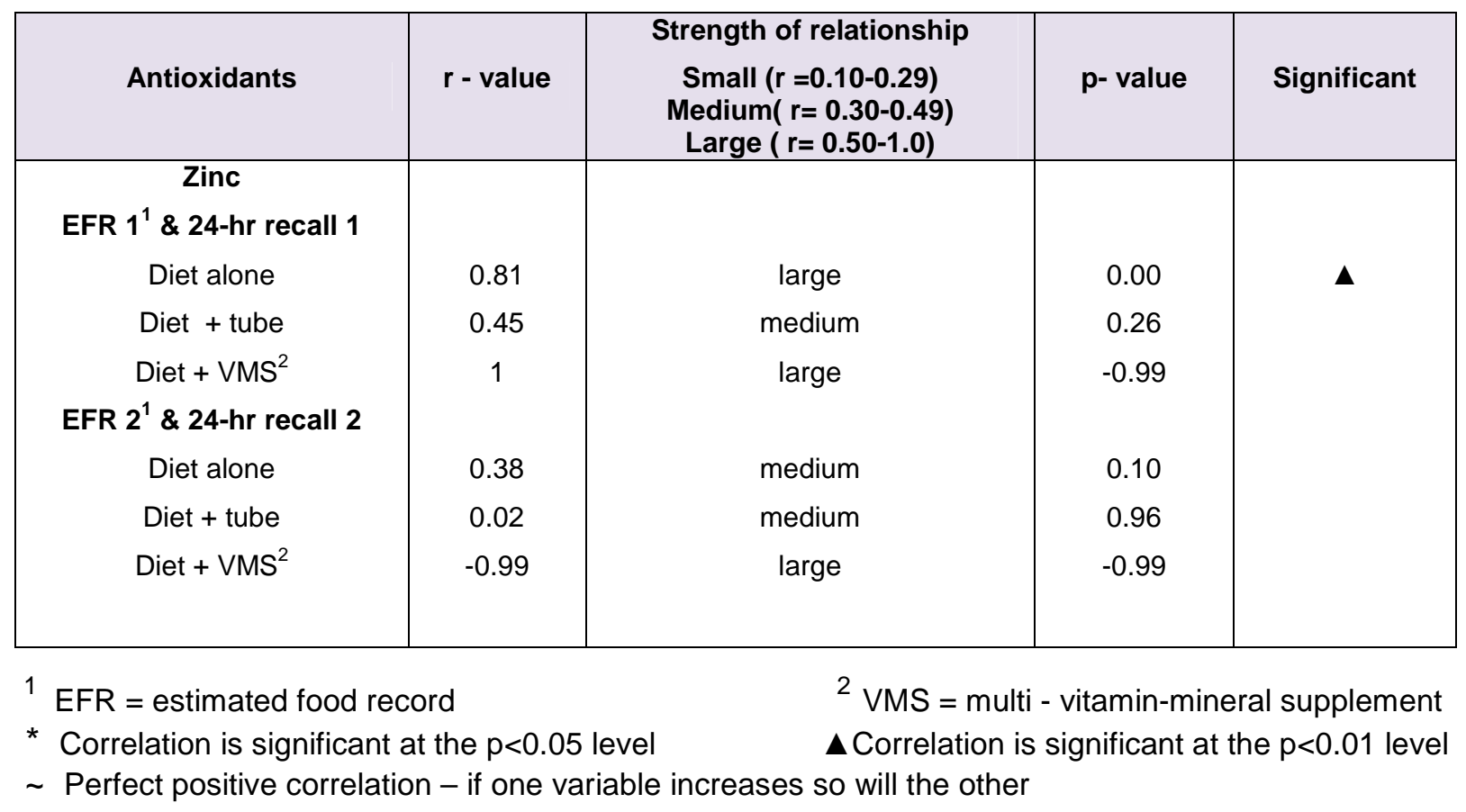

\subsection{CORRELATION OF DIETARY TOOLS FOR ENERGY AND PROTEIN INTAKE}

Similar results with highly statistical correlation were seen between EFR and 24-hr recalls with the diet alone mode of feeding when looking at protein and energy intake in Table 3.6. The following variables that were highly correlated in the $1^{\text {st }}$ month (EFR1) were; energy (diet alone; $p=0.00$; $r=0.85$ ), energy (diet alone; $p=0.00 ; r=0.77$ ) and protein (diet alone; $p=<0.05 ; r=0.79$ ). A further correlation was seen in the $3^{\text {rd }}$ month (EFR2) for protein (diet alone; $p=<0.01 ; r=0.54$ ). Once again the diet + tube group did not correlate well between the EFR and 24-hr recall. On closer inspection it was found that parents varied tube feed intake significantly from day to day. This was highly dependent on their child's toleration of oral intake and/or tube feeds during and post chemotherapy and radiotherapy sessions. Flexible tube feeding regimes were provided by the Dietitian to accommodate for the child's oral intake (retain normality of eating patterns), the need for additional top-ups of feed or weaning down of feed to improve tolerance. These factors would explain the poorer correlation in the diet + tube category. As the EFR and the repeated 24-hr recall were highly correlated for the majority of categories for protein and energy with significant numbers of children and as it represented four days of continuous dietary intake instead of non-consecutive days, further analysis was based on the EFR. 
Table 3.6 Correlation of the EFR and 24-hr recalls for mode of feeding and energy and protein intake $\left(1^{\text {st }}\right.$ and $3^{\text {rd }}$ months)

\begin{tabular}{|c|c|c|c|c|}
\hline Energy (kcal) & $\begin{array}{c}r- \\
\text { value }\end{array}$ & $\begin{array}{c}\text { Strength } \\
\text { Small }(r=0.10-0.29) \\
\text { Medium }(r=0.30-0.49) \\
\text { Large }(r=0.50-1.0)\end{array}$ & p- value & Significant \\
\hline \multicolumn{5}{|c|}{$\begin{array}{c}\text { EFR1 }^{1} \text { \& 24-hr recall } 1 \\
\text { (Energy) }\end{array}$} \\
\hline Diet alone & 0.85 & large & 0.00 & * \\
\hline Diet + tube & 0.77 & large & 0.00 & * \\
\hline \multicolumn{5}{|c|}{$\begin{array}{c}\text { EFR } 1^{1} \& \text { 24-hr } 1 \text { recall } \\
\text { (Protein) }\end{array}$} \\
\hline Diet alone & 0.79 & large & 0.00 & * \\
\hline Diet + tube & 0.30 & medium & 0.37 & \\
\hline \multicolumn{5}{|c|}{$\begin{array}{c}\text { EFR } 2^{1} \text { \& 24-hr recall } 2 \\
\text { (Energy) }\end{array}$} \\
\hline Diet alone & 0.29 & small & 0.21 & \\
\hline Diet + tube & 0.21 & small & 0.64 & \\
\hline \multicolumn{5}{|c|}{$\begin{array}{c}\text { EFR } 2^{1} \& \text { 24-hr recall } 2 \\
\text { (Protein) }\end{array}$} \\
\hline Diet alone & 0.54 & large & 0.01 & * \\
\hline Diet + tube & 0.36 & medium & 0.43 & \\
\hline
\end{tabular}

1 EFR = estimated food record

* Statistical significance determined at $p<0.05$

\subsubsection{COMPARISON OF ANTIOXIDANT INTAKES WITH DIETARY REFERENCE VALUES AND SAFE INTAKES}

\subsection{RECOMMENDED NUTRIENT INTAKE AND SAFE INTAKE FOR ANTIOXIDANTS}

The intakes of vitamin A, C, selenium and zinc were compared to each child's age appropriate RNI (Addendum N) and LRNI values (Addendum O). Children achieving greater than $100 \%$ and $200 \%$ of their RNI for each antioxidant are shown in Table 3.7.

The Chi-square test was used to ascertain a statistical difference in the number of children achieving their RNI's between the 3 modes of feeding in the $1^{\text {st }}$ month and $3^{\text {rd }}$ month (Table 3.7 and 3.8). In both the $1^{\text {st }}$ and $3^{\text {rd }}$ month there was a greater number of children achieving $\geq 100 \%$ $\mathrm{RNI}$ for vitamin A for diet + VMS (EFR1; $p=0.00$; EFR2; $p=0.00$ ) than the other feeding modes. The greatest number of children achieving $\geq 200 \%$ of $\mathrm{RNI}$ in the $3^{\text {rd }}$ month was for vitamin $\mathrm{E}$ (diet + 
tube; $p=0.01)$ and vitamin $C($ diet $+V M S ; p=0.01)$. There was not a significant difference in selenium and zinc intake between the modes of feeding in the $1^{\text {st }}$ and $3^{\text {rd }}$ month $(p$ - values ranging from 0.1 to 0.47$)$.

Differences in antioxidant intake $\left(\geq 100 \%\right.$ and $\geq 200 \%$ ) between the $1^{\text {st }}$ and $3^{\text {rd }}$ month were determined by means of the Exact Fisher test. There was no statistical difference seen between the number of children achieving their $\mathrm{RNI}$ for antioxidant intake between the $1^{\text {st }}$ and $3^{\text {rd }}$ month (Table 3.7 and 3.9). Of all the antioxidants, vitamin $\mathrm{C}$ achieved the highest intakes compared to the RNI (EFR1: diet + VMS; 773\% and EFR2: diet + tube: 829\%) (For further information see Addendum N). 
Table 3.7: Percentage of children achieving $\geq 100 \%$ and $200 \%$ of Recommended Nutrient Intake for antioxidants

\begin{tabular}{|c|c|c|c|c|c|c|c|c|c|c|c|c|}
\hline & \multicolumn{6}{|c|}{$\begin{array}{c}\text { EFR } 1^{1} \\
1^{\text {st }} \text { month }\end{array}$} & \multicolumn{6}{|c|}{$\begin{array}{c}\text { EFR 2 }{ }^{1} \\
3^{\text {nd }} \text { month }\end{array}$} \\
\hline & $\begin{array}{c}\text { Diet } \\
\geq 100 \%\end{array}$ & $\begin{array}{c}\text { Diet } \\
\geq 200 \%\end{array}$ & $\begin{array}{c}\text { Diet + } \\
\text { tube } \\
\geq 100 \%\end{array}$ & $\begin{array}{c}\text { Diet + } \\
\text { tube } \\
\geq 200 \%\end{array}$ & $\begin{array}{c}\text { Diet + } \\
\text { VMS }^{2} \\
\geq 100 \%\end{array}$ & $\begin{array}{c}\text { Diet + } \\
\text { VMS }^{2} \\
\geq 200 \%\end{array}$ & $\begin{array}{c}\text { Diet } \\
\geq 100 \%\end{array}$ & $\begin{array}{c}\text { Diet } \\
\geq 200 \%\end{array}$ & $\begin{array}{c}\text { Diet + } \\
\text { tube } \\
\geq 100 \%\end{array}$ & $\begin{array}{c}\text { Diet + } \\
\text { tube } \\
\geq 200 \%\end{array}$ & $\begin{array}{c}\text { Diet + } \\
\text { VMS }^{2} \\
\geq 100 \%\end{array}$ & $\begin{array}{c}\text { Diet + } \\
\text { VMS }^{2} \\
\geq 200 \%\end{array}$ \\
\hline Vitamin A & $\begin{array}{c}9 \% \\
(1 / 11)\end{array}$ & $\begin{array}{c}0 \% \\
(0 / 11)\end{array}$ & $\begin{array}{c}46 \% \\
(6 / 13)\end{array}$ & $\begin{array}{c}8 \% \\
(1 / 13)\end{array}$ & $\begin{array}{c}100 \% \text { * } \\
(8 / 8)\end{array}$ & $\begin{array}{l}25 \% \\
(2 / 8)\end{array}$ & $\begin{array}{c}0 \% \\
(0 / 10)\end{array}$ & $\begin{array}{c}0 \% \\
(0 / 10)\end{array}$ & $\begin{array}{l}50 \% \\
(4 / 8)\end{array}$ & $\begin{array}{l}13 \% \\
(1 / 8)\end{array}$ & $\begin{array}{l}75 \%{ }^{*} \\
(3 / 4)\end{array}$ & $\begin{array}{l}25 \% \\
(1 / 4)\end{array}$ \\
\hline Vitamin E & $\begin{array}{l}55 \% \\
(6 / 11)\end{array}$ & $\begin{array}{c}18 \% \\
(2 / 11) \\
\end{array}$ & $\begin{array}{c}77 \% \\
(10 / 13)\end{array}$ & $\begin{array}{c}38 \% \\
(5 / 13)\end{array}$ & $\begin{array}{l}88 \% \\
(7 / 8)\end{array}$ & $\begin{array}{l}63 \% \\
(5 / 8)\end{array}$ & $\begin{array}{c}50 \% \\
(5 / 10)\end{array}$ & $\begin{array}{c}0 \% \\
(0 / 10)\end{array}$ & $\begin{array}{l}88 \% \\
(7 / 8)\end{array}$ & $\begin{array}{l}63 \%{ }^{*} \\
(5 / 8)\end{array}$ & $\begin{array}{c}100 \%{ }^{*} \\
(4 / 4)\end{array}$ & $\begin{array}{l}50 \% \\
(2 / 4)\end{array}$ \\
\hline Selenium & $\begin{array}{c}36 \% \\
(4 / 11)\end{array}$ & $\begin{array}{c}0 \% \\
(0 / 11)\end{array}$ & $\begin{array}{c}69 \% \\
(9 / 13)\end{array}$ & $\begin{array}{c}8 \% \\
(1 / 13)\end{array}$ & $\begin{array}{l}43 \% \\
(3 / 7)\end{array}$ & $\begin{array}{l}14 \% \\
(1 / 7)\end{array}$ & $\begin{array}{c}20 \% \\
(2 / 10)\end{array}$ & $\begin{array}{c}0 \% \\
(0 / 10)\end{array}$ & $\begin{array}{l}63 \% \\
(5 / 8)\end{array}$ & $\begin{array}{l}25 \% \\
(2 / 8)\end{array}$ & $\begin{array}{l}50 \% \\
(1 / 2)\end{array}$ & $\begin{array}{c}0 \% \\
(0 / 2)\end{array}$ \\
\hline Zinc & $\begin{array}{c}36 \% \\
(4 / 11)\end{array}$ & $\begin{array}{c}0 \% \\
(0 / 11) \\
\end{array}$ & $\begin{array}{c}77 \% \\
(10 / 13)\end{array}$ & $\begin{array}{c}8 \% \\
(1 / 13)\end{array}$ & $\begin{array}{l}43 \% \\
(3 / 7)\end{array}$ & $\begin{array}{l}29 \% \\
(2 / 7)\end{array}$ & $\begin{array}{c}20 \% \\
(2 / 10) \\
\end{array}$ & $\begin{array}{c}0 \% \\
(0 / 10)\end{array}$ & $\begin{array}{l}63 \% \\
(5 / 8)\end{array}$ & $\begin{array}{l}25 \% \\
(2 / 8)\end{array}$ & $\begin{array}{l}50 \% \\
(1 / 2)\end{array}$ & $\begin{array}{l}50 \% \\
(1 / 2)\end{array}$ \\
\hline
\end{tabular}

${ }^{1} \mathrm{EFR}=$ estimated food record $\quad{ }^{2} \mathrm{VMS}=$ multi - vitamin-mineral supplement

() Brackets show number of children in that particular mode of feeding achieving $\geq 100 \%$ or $\geq 200 \%$ of Recommended Nutrient Intake ${ }^{(61)}$

$\sim$ Vitamin $\mathrm{E}$ is measured as a safe intake, no Recommended Nutrient Intake available

* This particular feeding mode had a statistically greater number of children achieving less than the lower recommended nutrient intake compared to the other feeding modes in that month 
Table 3.8: Chi-square Test comparing children achieving Recommended Nutrient Intakes between feeding modes in the $1^{\text {st }}$ and $3^{\text {rd }}$ Month ( $p$-value)

\begin{tabular}{|c|c|c|c|c|}
\hline & \multicolumn{2}{|c|}{$\begin{array}{c}\text { EFR 1 } \\
\mathbf{1}^{\text {st }} \text { month }\end{array}$} & \multicolumn{2}{c|}{$\begin{array}{c}\text { EFR 2 }^{\text {1 }} \\
\mathbf{m o n t h}^{\text {moth }}\end{array}$} \\
\cline { 2 - 5 } & $\begin{array}{c}\text { Diet / Diet + tube / Diet + } \\
\text { VMS }^{2} \\
(\geq 100 \%)\end{array}$ & $\begin{array}{c}\text { Diet / Diet + tube / Diet + } \\
\text { VMS }^{2} \\
(\geq 200 \%)\end{array}$ & $\begin{array}{c}\text { Diet / Diet + tube / Diet + } \\
\text { VMS }^{2} \\
(\geq 100 \%)\end{array}$ & $\begin{array}{c}\text { Diet / Diet + tube / Diet + } \\
\text { VMS }^{2} \\
(\geq 200 \%)\end{array}$ \\
\hline Vitamin A & $0.00^{*}$ & 0.17 & $0.00^{*}$ & 0.31 \\
\hline Vitamin C & 0.35 & 0.50 & 0.36 & $0.01^{*}$ \\
\hline Vitamin E & 0.25 & 0.14 & 0.08 & $0.01^{*}$ \\
\hline Selenium & 0.23 & 0.47 & 0.17 & 0.18 \\
\hline Zinc & 0.10 & 0.12 & 0.17 & 0.11 \\
\hline
\end{tabular}

1 EFR $=$ estimated food record

${ }^{2}$ VMS $=$ multi - vitamin-mineral supplement

${ }^{*}$ Significance at $p<0.05$

Table 3.9: Fisher Exact Test comparing children achieving Recommended Nutrient Intakes between the $1^{\text {st }}$ and $3^{\text {rd }}$ month for each Feeding mode ( $p$-value)

\begin{tabular}{|c|c|c|c|c|c|c|}
\hline & $\begin{array}{c}\text { Diet } \\
(\geq 100 \%)\end{array}$ & $\begin{array}{c}\text { Diet } \\
(\geq 200 \%)\end{array}$ & $\begin{array}{c}\text { Diet + tube } \\
(\geq 100 \%)\end{array}$ & $\begin{array}{c}\text { Diet + tube } \\
(\geq 200 \%)\end{array}$ & $\begin{array}{c}\text { Diet + VMS } \\
(\geq 100 \%)\end{array}$ & $\begin{array}{c}\text { Diet + VMS } \\
(\geq 200 \%)\end{array}$ \\
\hline Vitamin A & 0.99 & 0.99 & 0.99 & 0.99 & 0.33 & 0.99 \\
\hline Vitamin C & 0.63 & 0.08 & 0.99 & 0.99 & 0.99 & 0.99 \\
\hline Vitamin E & 0.99 & 0.47 & 0.99 & 0.38 & 0.99 & 0.99 \\
\hline Selenium & 0.63 & 0.99 & 0.99 & 0.53 & 0.99 & 0.99 \\
\hline Zinc & 0.63 & 0.99 & 0.63 & 0.53 & 0.99 & 0.41 \\
\hline
\end{tabular}

${ }^{1} \mathrm{VMS}=$ multi - vitamin-mineral supplement

*Significance at $p<0.05$ 


\subsection{LOWER RECOMMENDED INTAKE FOR ANTIOXIDANTS}

The number of children achieving lower than and equal to $100 \%$ of their LRNI between the 3 modes of feeding in the $1^{\text {st }}$ and $3^{\text {rd }}$ month are shown in Tables 3.10 and 3.11 and statistical significance was established using the Chi-square test. It showed that the least number of children to meet the LRNI for any antioxidant were in the diet alone group for vitamin A (EFR $1 ; \leq 100 \%$; diet alone; $p=0.00$ ) and zinc (EFR1; $\leq 100 \%$; diet alone; $p=0.02$ ) in the $1^{\text {st }}$ month. For all three feeding modes in the $3^{\text {rd }}$ month children were achieving vitamin $\mathrm{C}$ intakes greater than the LRNI (EFR2; $\leq 100 \%$; diet alone; diet + tube and Diet + VMS; $p=0.00)$. There was no significant difference seen in children achieving their LRNI for antioxidant intake $(\leq 100 \%)$ between the $1^{\text {st }}$ and $3^{\text {rd }}$ month (Table 3.12).

Table 3.10: Percentage of children achieving $\leq 100 \%$ of the Lower Recommended Nutrient Intake for antioxidants

\begin{tabular}{|c|c|c|c|c|c|c|}
\hline & \multicolumn{3}{|c|}{$\begin{array}{c}\text { EFR } 1^{1} \\
1^{\text {st }} \text { month }\end{array}$} & \multicolumn{3}{|c|}{$\begin{array}{c}\text { EFR } 2^{1} \\
3^{\text {nd }} \text { month }\end{array}$} \\
\hline & $\begin{array}{c}\text { Diet } \\
(\leq 100 \%)\end{array}$ & $\begin{array}{c}\text { Diet + tube } \\
(\leq 100 \%)\end{array}$ & $\begin{array}{c}\text { Diet + } \\
\text { VMS }^{2} \\
(\leq 100 \%)\end{array}$ & $\begin{array}{c}\text { Diet } \\
(\leq 100 \%)\end{array}$ & $\begin{array}{c}\text { Diet + tube } \\
(\leq 100 \%)\end{array}$ & $\begin{array}{c}\text { Diet + } \\
\text { VMS }^{2} \\
(\leq 100 \%)\end{array}$ \\
\hline Vitamin A & $\begin{array}{l}45 \% \%^{*} \\
(5 / 11)\end{array}$ & $\begin{array}{c}0 \% \\
(0 / 13)\end{array}$ & $\begin{array}{c}0 \% \\
(0 / 8)\end{array}$ & $\begin{array}{c}50 \% \\
(5 / 10)\end{array}$ & $\begin{array}{l}25 \% \\
(2 / 8)\end{array}$ & $\begin{array}{c}0 \% \\
(0 / 4)\end{array}$ \\
\hline Vitamin C & $\begin{array}{c}9 \% \\
(1 / 11)\end{array}$ & $\begin{array}{c}0 \% \\
(0 / 13)\end{array}$ & $\begin{array}{c}0 \% \\
(0 / 8)\end{array}$ & $\begin{array}{l}0 \% * \\
(0 / 10)\end{array}$ & $\begin{array}{l}0 \%{ }^{*} \\
(0 / 8)\end{array}$ & $\begin{array}{l}0 \% * \\
(0 / 4)\end{array}$ \\
\hline Selenium & $\begin{array}{c}9 \% \\
(1 / 11)\end{array}$ & $\begin{array}{c}0 \% \\
(0 / 13)\end{array}$ & $\begin{array}{l}29 \% \\
(2 / 7) \\
\end{array}$ & $\begin{array}{c}30 \% \\
(3 / 10)\end{array}$ & $\begin{array}{l}0 \% \\
(0 / 8)\end{array}$ & $\begin{array}{c}0 \% \\
(0 / 2)\end{array}$ \\
\hline Zinc & $\begin{array}{l}45 \% * \\
(5 / 11)\end{array}$ & $\begin{array}{c}0 \% \\
(0 / 13)\end{array}$ & $\begin{array}{l}29 \% \\
(2 / 7)\end{array}$ & $\begin{array}{l}50 \% * \\
(5 / 10)\end{array}$ & $\begin{array}{c}0 \% \\
(0 / 8)\end{array}$ & $\begin{array}{l}0 \% \\
(0 / 2)\end{array}$ \\
\hline
\end{tabular}

1 EFR = estimated food record

${ }^{2}$ VMS $=$ multi - vitamin-mineral supplement

( ) Brackets show fraction of children in that particular mode of feeding achieving $\leq 100 \%$ of Lower recommended nutrient intake ${ }^{(61)}$

* This particular feeding mode had a statistically greater number of children achieving less than the lower recommended nutrient intake compared to the other feeding modes in that month 
Table 3.11: Chi-square Test comparing children achieving Lower Recommended Nutrient Intake between feeding modes in $1^{\text {st }}$ and $3^{\text {rd }}$ month ( $p$-value)

\begin{tabular}{|c|c|c|}
\hline & $\begin{array}{l}\text { EFR } 1^{1} \\
1^{\text {st }} \text { month }\end{array}$ & $\begin{array}{l}\text { EFR } 2^{1} \\
3^{\text {nd }} \text { month }\end{array}$ \\
\hline & $\begin{array}{c}\text { Diet / Diet + tube / Diet + VMS } \\
(\leq 100 \%)\end{array}$ & $\begin{array}{c}\text { Diet / Diet }+ \text { tube / Diet }+ \text { VMS }^{2} \\
(\leq 100 \%)\end{array}$ \\
\hline Vitamin A & 0.00 * & 0.16 \\
\hline Vitamin C & 0.37 & 0.00 * \\
\hline Selenium & 0.11 & 0.17 \\
\hline Zinc & 0.02 * & 0.35 \\
\hline
\end{tabular}

1 EFR = estimated food record *Significance at $p<0.05$ (Chi-square test) ${ }^{*}$

${ }^{2}$ VMS $=$ multi - vitamin-mineral supplement

Table 3.12: Fisher Exact Test comparing children achieving Lower Recommended Nutrient Intake between the $1^{\text {st }}$ and $3^{\text {rd }}$ month for each feeding mode ( $p$-value)

\begin{tabular}{|c|c|c|c|}
\hline & Diet $(\leq 100 \%)$ & Diet + tube $(\leq 100 \%)$ & Diet + VMS ${ }^{1}(\geq 200 \%)$ \\
\hline Vitamin A & 0.99 & 0.13 & 0.99 \\
\hline Vitamin C & 0.99 & 0.99 & 0.99 \\
\hline Selenium & 0.31 & 0.99 & 0.99 \\
\hline Zinc & 0.99 & 0.99 & 0.99 \\
\hline
\end{tabular}

${ }^{1}$ VMS $=$ multi vitamin-mineral supplement

\subsection{COMPARISON OF ENERGY AND PROTEIN INTAKES TO ESTIMATED AVERAGE REQUIREMENTS}

The protein and energy requirement of each child was compared to the EAR as appropriate for the child's age (Addendum P). The number of children achieving greater than $100 \%$ and $200 \%$ of their EAR for protein and energy are shown in Table 3.13. The Fisher Exact test showed no statistical difference between the number of children attaining their EAR's between the 3 modes of feeding in the $1^{\text {st }}$ month and $3^{\text {rd }}$ month (see Table 3.14). No statistical significance between the modes of feeding in the $1^{\text {st }}$ month and $3^{\text {rd }}$ month was seen. Similarly there was no significant change seen in children achieving their EAR for energy and protein between the $1^{\text {st }}$ and $3^{\text {rd }}$ month $(\geq 100 \%)($ Table 3.15). 
Table 3.13: Percentage of children achieving greater than $100 \%$ and $200 \%$ of Estimated Average Requirement for energy and protein

\begin{tabular}{|c|c|c|c|c|c|c|c|c|}
\hline & \multicolumn{4}{|c|}{$\begin{array}{c}\text { EFR } 1^{1} \\
1^{\text {st }} \text { month }\end{array}$} & \multicolumn{4}{|c|}{$\begin{array}{c}\text { EFR 2 } \\
3^{\text {nd }} \text { month }\end{array}$} \\
\hline & $\begin{array}{c}\text { Diet } \\
\geq 100 \%\end{array}$ & $\begin{array}{c}\text { Diet } \\
\geq 200 \%\end{array}$ & $\begin{array}{c}\text { Diet + } \\
\text { tube } \\
\geq 100 \%\end{array}$ & $\begin{array}{c}\text { Diet + } \\
\text { tube } \\
\geq 200 \%\end{array}$ & $\begin{array}{c}\text { Diet } \\
\geq 100 \%\end{array}$ & $\begin{array}{c}\text { Diet } \\
\geq 200 \%\end{array}$ & $\begin{array}{c}\text { Diet + } \\
\text { tube } \\
\geq 100 \%\end{array}$ & $\begin{array}{c}\text { Diet + } \\
\text { tube } \\
\geq 200 \%\end{array}$ \\
\hline Energy & $\begin{array}{l}27 \% \\
(3 / 11)\end{array}$ & $\begin{array}{c}0 \% \\
(0 / 11)\end{array}$ & $\begin{array}{c}43 \% \\
(6 / 14)\end{array}$ & $\begin{array}{c}0 \% \\
(0 / 14)\end{array}$ & $\begin{array}{c}10 \% \\
(1 / 10)\end{array}$ & $\begin{array}{c}0 \% \\
(0 / 10)\end{array}$ & $\begin{array}{l}38 \% \\
(3 / 8)\end{array}$ & $\begin{array}{c}0 \% \\
(0 / 8)\end{array}$ \\
\hline Protein & $\begin{array}{c}91 \% \\
(10 / 11)\end{array}$ & $\begin{array}{c}73 \% \\
(8 / 11)\end{array}$ & $\begin{array}{c}100 \% \\
(14 / 14)\end{array}$ & $\begin{array}{c}64 \% \\
(9 / 14)\end{array}$ & $\begin{array}{c}80 \% \\
(8 / 10)\end{array}$ & $\begin{array}{c}40 \% \\
(4 / 10)\end{array}$ & $\begin{array}{l}100 \% \\
(8 / 8)\end{array}$ & $\begin{array}{l}63 \% \\
(5 / 8)\end{array}$ \\
\hline
\end{tabular}

${ }^{1}$ EFR $=$ estimated food record

( ) Brackets show fraction of children in that particular mode of feeding achieving $\geq 100 \%$ or $\geq 200 \%$ of Estimated Average Requirement

Table 3.14 Chi-square Test comparing children achieving Estimated Average Requirement between feeding modes in $1^{\text {st }}$ and $3^{\text {rd }}$ months ( $p$-value)

\begin{tabular}{|c|c|c|c|c|}
\hline & \multicolumn{2}{|c|}{$\begin{array}{c}\text { EFR 1 }{ }^{1} \\
1^{\text {st }} \text { month }\end{array}$} & \multicolumn{2}{|c|}{$\begin{array}{c}\text { EFR 2 } \\
3^{\text {nd }} \text { month }\end{array}$} \\
\hline & $\begin{array}{c}\text { Diet / Diet + tube / } \\
\text { Diet + VMS }{ }^{2} \\
(\geq 100 \%)\end{array}$ & $\begin{array}{c}\text { Diet / Diet + tube / } \\
\text { Diet + VMS } \\
(\geq 200 \%)\end{array}$ & $\begin{array}{c}\text { Diet / Diet + tube / } \\
\text { Diet + VMS }{ }^{2} \\
(\geq 100 \%)\end{array}$ & $\begin{array}{c}\text { Diet / Diet + tube } \\
\text { / Diet + VMS } \\
\text { ( } \geq 200 \%)\end{array}$ \\
\hline Energy & 0.99 & 0.99 & 0.25 & 0.99 \\
\hline Protein & 0.44 & 0.50 & 0.07 & 0.66 \\
\hline
\end{tabular}

${ }^{1}$ EFR $=$ estimated food record

${ }^{2}$ VMS $=$ multi - vitamin-mineral supplement

Table 3.15 Fisher Exact Test comparing children achieving Estimated Average Requirement between the $1^{\text {st }}$ and $3^{\text {rd }}$ month for each feeding mode in the Estimated Food Record (p-value)

\begin{tabular}{|c|c|c|c|c|}
\hline & Diet $(\geq 100 \%)$ & Diet ( $\geq 200 \%)$ & Diet + tube $(\geq 100 \%)$ & Diet + tube ( $\geq 200 \%)$ \\
\hline Energy & 0.59 & 0.99 & 0.99 & 0.99 \\
\hline Protein & 0.59 & 0.20 & 0.99 & 0.99 \\
\hline
\end{tabular}




\subsubsection{FAT-SOLUBLE VITAMINS (A and E) AND SAFE UPPER INTAKES}

The vitamin $A$ and $E$ intakes were compared against the Safe Upper Intake advised by and cited by the $\mathrm{DOH}(\mathrm{UK})$ (Addendum D). ${ }^{(16)}$ Neither the Vitamin A or E exceeded the Safe Upper Intakes despite the use of tube feeding (including food supplements) and vitamin and/or mineral supplements (For further information see Addendum N).

\subsubsection{PREVALENCE AND TYPE OF VITAMIN-AND/OR MINERAL SUPPLEMENT USE}

Of the children who returned their EFR in the $1^{\text {st }}$ month, $27 \%(n=8)$ consumed vitamin and/or mineral supplements and $18 \%(n=4)$ in the $3^{\text {rd }}$ month. The vitamin and/or mineral supplements were further divided into two categories namely vitamin supplement (VS) and multi vitamin-mineral supplement (MVMS) (Table 3.16). More children consumed vitamin supplements ( $n=5 ; 63 \%)$ compared to multi-vitamin-mineral supplements $(n=3 ; 24 \%)$ in the $1^{\text {st }}$ month. However the use of both VS and MVMS decreased between the $1^{\text {st }}$ and $3^{\text {rd }}$ month. In general the types of vitamins and mineral supplements used in the sample population were: MVMS - Wellkids soft and chewable $(n=1 ; 2 \%)$; Sanatogen A-Z children ( $n=1 ; 2 \%)$, Adult Tesco A-Z multivitamin-mineral $(n=1 ; 2 \%)$, My First Flintstones $(n=1 ; 2 \%)$ and for VS: Dalivit $(n=1 ; 2 \%)$, Bassetts soft and chewy pastilles, ASDA Great Stuff chewy pastilles $(n=2 ; 5 \%)$, Kia Ora Real Fruit Pastilles $(n=1 ; 2 \%)$ and Seven Seas vitamin and mineral tonic $(n=1 ; 2 \%)$.

Table 3.16 Frequency of use of multivitamin-mineral and vitamin based supplements in Estimated Food Records

\begin{tabular}{|c|c|c|}
\hline & $\mathbf{1}^{\text {st }}$ month & $3^{\text {rd }}$ month \\
\hline MVMS $^{1}$ & $3 / 8$ & $2 / 4$ \\
& $(24 \%)$ & $(50 \%)$ \\
\hline VS $^{2}$ & $5 / 8$ & $2 / 4$ \\
& $(63 \%)$ & $(50 \%)$ \\
\hline
\end{tabular}

\footnotetext{
${ }^{1}$ MVMS - multi vitamin-mineral supplement

${ }^{2}$ VS - vitamin supplement
} 
CHAPTER 4 DISCUSSION 


\subsection{INITIAL OBSERVATIONS}

This prospective analysis of forty two children with cancer suggested a vulnerability to antioxidant, and energy depletion in certain modes of feeding. Few published paediatric studies exist analysing the dietary antioxidant, energy and protein intake of children with cancer, especially in determining the threshold at which the antioxidant intakes could interfere with cancer treatment or decrease the side effects during treatment.

\subsection{OUTCOMES}

\subsubsection{ASSESSMENT OF DIETARY INTAKE}

This study relied on both EFR and repeated 24-hr dietary recalls (test method) to establish dietary intake. Both methods have well established strengths and weaknesses. The strengths of the $24 \mathrm{~h}$ recall include; inexpensive and quick to administer, provides detailed information on specific foods and requires a low effort by participants thus supported well. Conversely the 24-hr recall is limiting in that subjects can withhold or alter information on what they have eaten due to poor memory, embarrassment or to please the researcher. However the primary limitation of the 24-hr recall is that data from a single-days diet could be a poor descriptor of an individual's usual nutrient intake due to intra-individual or day-to-day variability. ${ }^{(56)}$ Strengths of the EFR include; no reliance on memory as meals/snacks and beverages were documented at the time of eating. Multiple day data is also more representative of usual intake than one 24-hr recall or a 1-day food record. Therefore the 24-hr recall and EFR complement each other in extracting information. The limitations in this study were that respondents needed to be literate and be willing to give the time and effort. ${ }^{\text {(56) }}$ As there was no standardised or validated EFR available in English that could elicit antioxidant intake in children, an EFR was developed and assessed prior to use.

These dietary methods were tested in the pilot study that included four children, all of which were incorporated into the main study data. The main functions of the pilot study were to test the adequacy of the research tools, assess the feasibility for the study, establish whether the technique was effective, identify logistical problems with recruitment, and variability in outcomes to help determine sample size. ${ }^{(62)}$ There is however limitations to pilot studies in that they do provide some indication to the likely sample size of the main study, but cannot guarantee this; due to being based on small numbers. A further limitation is the contamination of data that can occur if pilot study data is incorporated into main study data. ${ }^{(62)}$ This usually occurs if significant modifications are made to the research tools. ${ }^{(62)}$ The researcher for this study chose to incorporate the pilot data into the main study. This decision was taken due to only minor amendments being made to the research tools as recommended by external independent paediatric dietitian experts (face validity) 
and the slow recruitment of children into this study; this additional data was invaluable to the study sample size. As the amendments did not affect the validity of the dietary intake data already collected for these 4 children, this data was included in the analysis.

Good correlation, with no day-to-day or week-to-week variability was seen between the research tools for children on diet alone; however variability was seen in children on diet + tube. There were too few children in the category of diet + VMS to obtain meaningful interpretation of variability. On closer inspection the variability in the diet + tube group was compounded by frequent adjustments to feed amounts given to the child. It was found that parents varied tube feed amounts significantly particularly during and post chemotherapy and radiotherapy sessions. Flexible tube feeding regimens were provided by the Dietitian to accommodate the child's oral intake as well as side effects from treatment; therefore retaining the normality of eating. Parents are encouraged to adhere to these suggested volumes to ensure adequate nutrition; however parents are autonomous at home. The numbers of adjustments in the tube feeding amounts are also associated with the cancer type and nutritional risk. Ninety five percent of the children in this study were at high nutritional risk that is indicative of the intensity of treatment regimes and likelihood of feed adjustments. A further contributing factor to variability could be due to the 24-hr recall being performed 1 week after the EFR. The children undergo many changes from week to week with regard to treatment sessions, mucositis, appetite changes, etc. The combination of all these factors would explain the poorer correlation in the diet + tube category. Palaniappan ${ }^{(63)}$ suggested that in itself the diet alone category experiences inter and intra subject variability however daily and weekly oral intakes tend to average. This was demonstrated in the diet alone category; however the additional compounding factors associated with diet + tube category are more difficult to overcome. As the EFR and the repeated 24-hr recall were highly correlated for the majority of categories for protein and energy with significant numbers of children and as it represented four days of continuous dietary intake instead of non-consecutive days, further analysis was based on the EFR. Future studies with children on diet + tube should recall intake in the same week as the EFR. This could potentially improve correlation; however a limitation to this approach would be that participants could read off the EFR and not recall intake from memory.

In the $3^{\text {rd }}$ month the increased variability and/or lower correlation could also be due to the poorer return rate of EFR's in comparison to the number of 24-hr recalls obtained. Maclntyre noted that the response rate expected from food records was between $65-95 \%$ and this was dependent on who it was taken from and under what conditions. ${ }^{(64)}$ In this study $71 \%$ of the respondents returned the EFRs in the $1^{\text {st }}$ month and only $52 \%$ in the $3^{\text {rd }}$ month. It can be argued that children receiving additional food supplements/tube feeding were in the higher nutritional risk group and therefore high risk cancers. ${ }^{(39)}$ The latter will require intensive cancer treatment, potentially more inpatient admissions; side effects of treatment and require more time given to feeding in general. In addition 
the emotional burden on parents caring for a child with cancer would also influence response rates. All these factors may influence the time available to complete food records and therefore decrease the response rate selectively in this group.

In an effort to reduce variability a useful research tool that could be incorporated in subsequent studies is the food frequency questionnaire. This tool accommodates high day-to-day variability. This tool was suggested by an independent reviewer of the EFR for the purpose of yielding additional information about antioxidant intake. Food frequencies have their niche in targeting particular nutrients in question and are preferable in nutrients with a very high day-to-day variability. However, they are less sensitive to the absolute intake for specific nutrients and are highly reliant on memory. ${ }^{(57)}$ Due to the lack of 'English' validated FFQ's for specifically paediatric antioxidant intake this method was not used in this study. Future research could develop and validate such a tool and this would be useful in establishing antioxidant intake in this population.

\subsubsection{NUTRITIONAL STATUS}

The implications of malnutrition in children on cancer treatment are well known. In this study the nutritional risk of children against their cancer type showed that $95 \%$ were at high risk and only $5 \%$ at low risk of developing malnutrition. Therefore it could be hypothesised that there would be a high prevalence of malnutrition in this study population. However despite the high nutritional risk only $5 \%$ of the children in the $1^{\text {st }}$ month and $10 \%$ in the $3^{\text {rd }}$ month fell within the moderately malnourished category (<-2 z-score). No children fell within in the severely malnourished group (<$3 z$-score.) The mean z-score of the population of -0.22 and -0.34 was further indicative of a well nourished population. Donaldson et al. ${ }^{(5)}$ and Van Eys, ${ }^{(4)}$ presented data on the incidence of malnutrition in paediatric oncology children in the range of 6 to $50 \%$ depending on the type, stage and location of the tumour. Therefore this study population comparatively attained results in the lower percentage for malnutrition. Recently a study by Garofola, ${ }^{(65)}$ found that children with Solid tumours still achieved higher percentages of deficits for MUAC, weight for height z-scores and arm muscle circumference compared to other cancer groups. It is difficult to find specific comparable studies due to different cohorts of cancer groups, measurement of malnutrition and cancer staging. Factors influencing the ability to find comparable studies/current information on the incidence of malnutrition are outlined by Bauer et ${ }^{a l} ;{ }^{(66)}$ a.) the child's susceptibility toward malnutrition and anticancer treatments during classification, b.) the non-specific definition of malnutrition, c.) the stage and histological type of cancer during assessment and d.) the different methods of assessing nutritional status. The Solid tumour group showed the greatest prevalence of moderate malnutrition in the $3^{\text {rd }}$ month in comparison to the other cancer groups. It would be reasonable to say that despite other studies using different measurement techniques one can compare the prevalence of malnutrition. 
Despite the initial assessment of a high percentage of children being at nutritional risk, few were classified as malnourished. This may be due to the nutritional practices in place to prevent malnutrition in children admitted to the hospital. One of the possible contributing factors towards the prevention of severely malnourished children was the use of the nutritional support algorithm (Addenbrookes Hospital; Appendix J). This algorithm clearly shows which children are at greater nutritional risk and criteria for early intervention with nutrition support. This algorithm was supported by and practised by the whole oncology team and regular counselling was provided by the specialist paediatric Dietitians. However without a comprehensive evaluation/audit of this algorithm it can only be hypothesised. The key to the success of any research study of this type is the implementation of strategies, which will address the areas of nutritional risk for that particular population group.

Interestingly, however this study found that children with Leukaemia presented with a higher prevalence of obesity in comparison to the other cancer groups. The results showed that $3 \%$ of the children were overweight $(z$-score $>2)$ in the $1^{\text {st }}$ and $3^{\text {rd }}$ month. Many studies substantiate these findings and are described by Bechard and Mayer et al. ${ }^{(67,68)}$ These authors showed that increases in obesity rates were seen in survivors of Acute lymphobastic leukeamia treated with cranial radiation. This correlated significantly with decreases in resting energy expenditure and physical activity. The second study examined a combination of indirect calorimetry and ambulatory heart rate that monitored basal metabolic rate and total energy expenditure. It was concluded that Acute lymphoblastic survivors had a lower energy expenditure and physical activity level than healthy children and encountered significant earlier adiposity rebound (body mass index begins to increase after its nadir in childhood). ${ }^{(67,69)}$ Studies showed that Acute lymphoblastic leukaemia survivors had significantly higher whole body fat percentages, however similar body mass index values compared to controls. This suggested the need for body composition measurements to clarify fat composition changes in the body. ${ }^{(67)}$

Weight-for-age was used as a measurement tool to assess the malnutrition status of this study population. This gave an indication of current nutritional status, but not of the progression of disease, as height measurements were not taken. In this study the height parameter was not used as more often than not this routine measurement was not performed for a variety of reasons namely; vincristine induced neuropathy which resulted in children being too weak to stand, refusal by the toddlers, busy clinics and children attending clinics on a weekly basis and therefore too frequent to measure height to determine growth. This was highlighted in a recent audit on the children's wards, auditing the completion of the Paediatric Yorkhill Malnutrition Score (PYMS) tool. ${ }^{(70)}$ The PYMS tool was developed and initiated in the UK in an attempt to screen nutritional risk in children in the hospital setting. In this study the primary objective was to investigate antioxidant, protein and energy intakes; although having a height measurement would be 
desirable. The absence of this measurement did not impact the results of this study. Though weight was primarily used in the weight-for-age z-scores, we need to be mindful that body weight is not a sufficiently and adequately sensitive marker for the recognition of nutritional perturbation. This is in particular relation to children with large solid abdominal masses (e.g. Neuroblastoma, Hepatoblastoma or Wilms tumour) as they may present with a normal weight despite severe malnutrition. ${ }^{(66)}$ It may therefore be that the prevalence of malnutrition in this study's Solid tumour population may have been higher if a more sensitive measurement tool was used e.g. MUAC. Body weight measurements can also be affected by hydration provided during chemotherapy, corticosteroid treatment and oedema therefore masking the loss of skeletal muscle and fat. ${ }^{(66)} \mathrm{A}$ study by Sala recommended that mid-upper arm circumference and triceps skin folds could also be useful in assessing nutritional status, as they were not influenced by the tumour weight and were more sensitive than weight alone. ${ }^{(2)}$ MUAC was however not performed in this study as it does not form part of routine hospital care for these children. In future studies it would be interesting to use a similar demographic of population and measure weight, height, MUAC and skinfold thickness and compare the incidence of malnutrition to the results of this study.

An interesting finding from the study was that despite few of the children achieving adequate energy intakes (by calculation) across all three feeding modes they did consume very good protein intakes and still only presented few children with moderate malnutrition ( $1^{\text {st }}$ month; $n=2$ and $3^{\text {rd }}$ month; $n=4$ ). The article by Scrimshaw relates to this particular finding in describing the close interrelationship between energy and protein metabolism. ${ }^{(71)}$ A number of short-term studies had shown that protein intake required for nitrogen equilibrium decreased with increasing energy intake. This occurred not only when the initial energy intake level was deficient but also when the intake exceeded requirements. Conversely, a reduction of protein intake whilst energy intake remained constant could reduce the velocity of growth in terms of weight and height, even when the nitrogen balance was positive. The mechanisms producing these effects are not clear. Also known is that with an energy intake that is borderline or inadequate, an increase in protein intake can result in improved weight gain. ${ }^{(71,72)}$ Energy requirements for maintenance of weight and normal body composition may be less when dietary protein is adequate. ${ }^{.(71)}$ There is also the potential that the calculations used for energy requirements are not adequately predicting what is required for these children. Except for post-prandial thermogenesis, protein intake does not have a specific effect on energy. ${ }^{(71)}$ Although no data exists from this study, it may be hypothesised that with treatment (in particular radiation) and disease progression that these children may become stunted during and after treatment. This is substantiated by findings in two studies examining linear growth velocity in children undergoing Hematopoietic stem cell transplantation. ${ }^{(67)}$ In both studies it was found that in children undergoing full body irradiation that their final height compared to their height pre transplant had decreased in peak height velocity. Some children had achieved a height 
considered to be within normal parameters. Radiation could therefore be assumed to be the main element of growth stunting.

To this day there is still no single ideal tool to accurately measure children or adults nutritional status. Attempts to predict the influence of malnutrition based on single measurements fail to consider the many interacting factors between nutrition and disease state. Therefore for this purpose nutritional status cannot be reliant on one measurement and one needs to use a combination of measurements/tools to achieve this. To ensure a comprehensive assessment of nutritional status the following criteria should be measured; anthropometry, biochemical/haematological variables, clinical and physical assessment and dietary intake. ${ }^{(64)}$

\subsubsection{NUTRITION REQUIREMENT AND NUTRITIONAL SUPPORT}

Appropriate dietary assessments and support throughout cancer treatment is essential. This study highlighted a consistent trend in the $1^{\text {st }}$ and $3^{\text {rd }}$ month where children on diet alone were put at particular risk of antioxidant (except for vitamin C) and energy depletion. One would aim to at least achieve the RNI for these antioxidants during chemotherapy. Comparatively the combination of diet + VMS achieved the greatest number of children with a significant high intake of vitamins $A, C$, and $\mathrm{E}$. Selenium and zinc intakes did not achieve statistical significance in the number of children achieving their RNI for any of the modes of feeding. This is likely to be because of the use of vitamin supplements that do not contain these minerals. Kennedy et al. ${ }^{(11)}$ found similar antioxidant results to this study population's i.e. antioxidant intakes were inadequate in children with ALL, except for vitamin C. In that study it was reported that throughout the 6-month study period, subjects ingested vitamin E, total carotenoid, B-carotene, and vitamin A in amounts that were $66 \%$, $30 \%, 59 \%$, and $29 \%$, respectively, of the US Recommended Dietary Allowance or of the amounts specified in the third National Health and Nutrition Examination Survey. ${ }^{(11)}$ Greater vitamin C intakes at 6 months were associated with fewer therapy delays, less toxicity, and fewer days spent in the hospital. Greater vitamin E intakes at 3 months were associated with a lower incidence of infection and greater B-carotene intakes at 6 month were associated with a decreased risk of toxicity. Kennedy et al. ${ }^{(11)}$ was able to substantiate his findings with plasma antioxidant concentrations. In this study adequate levels of vitamin $C$ intakes were shown in every mode of feeding. The higher vitamin $\mathrm{C}$ results were likely due to the predominant higher intake of fruit juice, squash, tube feeds and vitamin supplements from observation of the dietary analysis.

Adequate intakes of vitamin $\mathrm{C}$ were seen in all the feeding categories with a minimum of $70 \%$ of the children achieving their RNI. Children did however also notably consume high vitamin $\mathrm{C}$ intakes compared to the RNI up to $773 \%$ (232mg) in the diet + VMS category and $829 \%$ (292mg) in the diet + tube category. This does raise concern as to whether the intakes of these children 
could pose an interference with chemotherapy/radiotherapy and/or toxic levels. The DOH advises in broad terms that high intakes in the region of grams/day of vitamin $\mathrm{C}$ could cause diarrhoea, increased production of oxalate and hence kidney stones (exact grams not specified). ${ }^{(16)}$ Upon review, none of the children in this study were achieving greater than $1 \mathrm{gram} /$ day. Sixty to eighty eight percent of children on nutritional support (i.e. tube feeding and/or food supplements) were achieving their RNI antioxidant intakes; except for vitamin A. Vitamin A is closely associated with growth. Zinc intake was poor amongst the population with the following percentages of children not achieving their RNI respectively 64\% (diet alone); 23\% (diet + tube) and 57\% (diet + VMS). In the $3^{\text {rd }}$ month the percentage children not achieving their RNI increased to $80 \%$ (diet alone), $37 \%$ (diet + tube) and 50\% (diet +VMS). Once again diet alone had the greatest number of children not achieving their LRNI for zinc at $55 \%$ in the $1^{\text {st }}$ month and $50 \%$ in the $3^{\text {rd }}$ month.

The LRNI results showed a similar trend to RNI, in that the diet alone group had the greatest number of children not meeting the LRNI. This was in particular respect to vitamins $A$ and $E$, selenium and zinc. The role of vitamin A and zinc in growth is well documented. They function as essential nutrients in cell differentiation, development and linear growth. Numerous studies discuss the inhibition of growth in the presence of zinc deficiency. Growth occurs through cell division and requires DNA, RNA and protein synthesis. Zinc deficiency could result in reduced production of growth hormone and/or insulin-like growth factor-I. ${ }^{(74,73)}$ MacDonald reported that in animals fed a zinc-inadequate diet, both the growth and food intake decreased within 4-5 days. ${ }^{(73)}$ Despite the accompanying decrease in growth and food intake, the decreased energy intake was not the limiting factor in growth. This was demonstrated by the lack of growth seen in animals force fed a zinc inadequate diet. Therefore this shows that food intake and growth are regulated by zinc through coordinated and independent mechanisms. ${ }^{(73)}$ Rising et al. ${ }^{(75)}$ noted from their study on rats that by giving immunoreactive exogenous recombinant human growth hormone enhanced weight gain with suboptimal energy and zinc intake conditions however did not modify energy expenditure or physical activity index. A suboptimal zinc intake did not worsen the reduced growth or reduction in energy expenditure observed with energy restriction. ${ }^{(75)}$ Vitamin $A$ is also essential in the activities of epiphyseal-cartilage cells, which are required to carry out time sequence of growth, maturation, and degeneration essential in the mechanism of endochondral or replacement bone growth. ${ }^{(76)}$ The exact effect of vitamin A on the latter was not studied in this study.

In this study the children achieved a lower energy intake than the EAR and an adequate protein intake. A comparable Swedish study was undertaken looking at the macronutrient (i.e. energy, protein and carbohydrates) intake in malignant children undergoing chemotherapy in relation to the Swedish Nutrition Recommendations in the hospital and home environment (SNR). ${ }^{(12)}$ These findings showed that the average daily energy intake decreased from $91 \%$ of the SNR recommendation before chemotherapy to $69 \%$ after starting chemotherapy. On the hospital ward 
only $63 \%$ achieved their SNR and despite being discharged home were only able to increase their energy intake to $77 \%$ of the SNR. ${ }^{(12)}$ It was suggested that growing children and adolescents with chronic diseases have increased requirements for energy, protein, fat and carbohydrate, although the extent of the increase is not known exactly. ${ }^{(12)}$. A further study by Michaelsen et al. ${ }^{(77)}$ proposed that average energy intake for the children with cancer might be about 2 standard deviations above the recommendations for healthy children. ${ }^{(12)}$ Unfortunately no exact national recommendations exist on the intakes for energy, protein or antioxidant intake, and at what level higher intakes of antioxidants could potentially interfere with treatment. One would assume that children on cancer treatment should be provided with nutrients to at least achieve their RNI to sustain normal body functioning. The DOH advises that if a child's intake lies between the LRNI and RNI that it is more likely that they will have adequate dietary intakes; whereas those children with a habitual dietary intake below the LRNI are unlikely to be consuming adequate nutrients to maintain normal body functioning. ${ }^{(16)}$ Therefore awareness needs to be raised of the importance of measuring children's height to check for appropriate linear growth, as well as monitoring children for showing any clinical signs of deficiency. This should then be confirmed by means of appropriate blood tests. This should be considered as additional measurements in future studies.

From the findings of this study it would seem pertinent that detailed dietary analysis and early supportive nutrition is needed in cancer treatment. According to a review by El-Mantary, ${ }^{(45)}$ aggressive nutritional rehabilitation is very important in improving the outcome in cancer children in catabolic states. With an underlying malignancy, in addition to the aggressive chemo- and radiotherapy, it is not uncommon to have difficulty in establishing adequate nutrition via the oral route. ${ }^{(45)}$ In particular cancer groups it was found that early aggressive nutritional support was needed to improve outcome. This was clearly indicated in an publication by Ward et al. about early initiation of PEG feeding in children with Medulloblastomas (Solid tumours). ${ }^{(51)}$ These children experience significant problems including weight loss, vomiting and constipation early on in treatment. One of the centres in the study demonstrated a superior nutritional outcome when compared statistically to the two centre's that fed only as a response to nutritional decline. Nutritional assessment and support should be integrated into treatment protocols for all children with neoplastic diseases. ${ }^{(47)}$

In children with cancer much emphasis is placed on ensuring growth and therefore the focus is shifted to energy and protein intake. This over-shadows the equally vital intake of micronutrients. Ensuring an adequate intake of macro- and micronutrients becomes challenging with a child experiencing side effects of decreased appetite, taste changes, vomiting and nausea. ${ }^{(1)}$ Without guidance on requirements for vitamins and minerals in cancer treatment this is often a neglected area of nutrition. 


\subsubsection{VITAMIN AND/OR MINERAL SUPPLEMENTATION}

The consumption of vitamin-mineral supplements was surprisingly low in this study population namely $27 \%$ in the $1^{\text {st }}$ month and $18 \%$ in the $3 r d$ month in comparison to other similar studies. This study did not determine the reasons for vitamin and mineral consumption as this was not one of the main objectives. Recent surveys of children with cancer demonstrated that $25 \%$ to $84 \%$ used nutritional supplements containing antioxidants and often at doses higher than the RDA. ${ }^{(78)}$ Further to that survey, studies by Bussieres et al. ${ }^{(79)}$ and Mottonen et al. ${ }^{(80)}$ showed that $20 \%$ and $40 \%$ respectively of their children used vitamins. Mega-dose supplementation of vitamin B complex, C, and $\mathrm{E}$ was documented in the studies by Kennedy et al. ${ }^{(11)}$ and Neuhouser at $36 \%$ and $28 \%$ respectively of the study population. ${ }^{(81)}$

Routinely children on the ward request advice on vitamin-mineral supplements, however as no concise evidence on actual dosing is available, the general advice from healthcare professionals may vary. The general advice includes when you may want to consider vitamin-mineral supplements e.g. poor oral intake, limited variety in diet. No singular vitamin or mineral supplement is usually recommended instead a general vitamin - mineral supplement that does not exceed the RNI. Ward, ${ }^{(1)}$ recommends that until further studies are published on the role of antioxidants and interactions that it is sensible that vitamins and mineral should not be supplemented above the RNI. Parents are more aware of vitamin and mineral supplementation when their child has cancer, especially antioxidants. The rationale for using antioxidants during treatment is to ameliorate the side effects and depletion of antioxidants during treatment. There are however numerous publications to suggest that increased amounts of antioxidants may potentially interact with the chemotherapy and radiotherapy and the way in which it causes apoptosis in the cells. Kennedy et al. ${ }^{(11)}$ does not advocate supplementation during treatment with antioxidants due to the probable interference with cancer treatment; despite their study showing that the population group did not meet recommended dietary intakes. The study by Kennedy et al. ${ }^{(11)}$ did not make reference to whether supplementation insinuated excessive supplementation or supplementation to established $\mathrm{RNI}$ requirements.

Comparison of the children's fat-soluble vitamin intakes to safe upper ranges showed no excessive intakes (vitamins $\mathrm{A}$ and $\mathrm{E}$ ). It is known that fat-soluble vitamins taken at recommended amounts on a daily basis are essential to maintain good health; however mega-doses could be toxic. This is due to the body's ability to store fat-soluble vitamins for long periods and therefore posing a greater risk of toxicity than with water soluble vitamins when consumed in excess. Although vitaminmineral supplements were used by this study population, it was at a low prevalence in comparison to other similar studies. None of the children exceeded the guidance for maximum intakes of antioxidants. 
CHAPTER 5 CONCLUSIONS AND RECOMMENDATIONS 
Nutritional support in cancer treatment remains a complex subject. New research is keenly awaited to demystify the theory of antioxidant interference in cancer treatment and the actual requirements needed during illness. This also pertains to the actual requirements for calories and protein intake for children with cancer.

In this study a large proportion of the children undergoing treatment for Leukaemia, Lymphoma and Solid tumours displayed inadequate intakes of antioxidants and energy. The diet alone feeding mode was highlighted as the most nutritionally depleted in antioxidants and energy. This was a consistent trend seen both at diagnosis and 3 months into treatment. The consequences of malnutrition (increased side effects, infections, mortality and morbidity) are well documented and are multiple in children who are undernourished compared to these well-nourished during cancer treatment. Vitamin A and zinc were highlighted as especially depleted in the diet alone mode. It is known from numerous published studies on vitamin $A$ and zinc, that poor growth (in particular linear growth) is seen in vitamin A and zinc deficiency. On the other hand vitamin $C$ in particular with lower proportions of other antioxidants were achieving greater than $200 \%$ of the RNI and in some instances up to seven times the RNI. This was found specifically with the children on diet plus vitamins and/or mineral supplements. The data showed that there was a tendency towards the use of vitamin supplements and not mineral and trace element supplementation that may explain inadequate intakes of selenium and zinc. It therefore highlighted the need for education with regard to wiser choices of vitamin and mineral supplement purchases, if children require a supplement. High intakes of antioxidants (vitamin $C$ ) and in some cases vitamin $A$ and $E$ raised the issue of toxicity if used on a long term basis but also most importantly the controversial debate around the interference of antioxidants in apoptosis during chemotherapy and/or radiation. This is a real dichotomy.

A weakness of this study was its inability to obtain the full set of EFR's and 24-hr recalls for data analysis. However it is known that EFR's have a poorer return rate and taking into account the burden that cancer treatment places on children and their families, it would seem understandable given the context. The data collection periods were in the 1st and 3rd months of diagnosis, however in some cases children were not discharged from hospital within the allotted time frames due to infections or the type of treatment they were receiving. This was particularly seen in the AML and Non-hodgkins lymphoma cancer groups. This in turn affected the time frame in which the 24-hr recall and subsequent EFR2 could be completed and returned. Only once the 24-hr recall was completed could the parents complete the EFR. Similarly the time frames were not always exactly adhered to due to children being re-admitted for their treatment block, infections, neutropenia or surgery, among other reasons. This influenced the continuity of data collection. 
The EFR and 24-hr recall correlated well with particular reference to diet alone (vitamin A, C, E and zinc, energy and protein). However the EFR and 24-hr recall were limiting in their ability to obtain similar data between the two weeks in the diet + tube category. This was highly influenced by the significant day-to-day and week-to-week variability of children's' nutritional intake and side effects and hence the need for feed adjustment. As previously discussed, the Dietitians provided a flexible feeding regimen to accommodate for variable oral intake and parents were autonomous at home. Although it may be perceived as a limitation that not both the 24-hr recall and EFR were analysed for the diet + tube group, the researcher found, that there were such significant differences even between the repeated 24-hr recalls (parents varied the tube feeds), that the EFR would provide the most reliable data and that the addition of the repeated 24-hr recall would not add any further information.

A significant shortcoming for this study and other similar studies was the lack of National Standards for antioxidant, protein and energy intakes in children with cancer. The Dietary Reference Values consist of a series of estimates of the amount of energy and nutrients needed by different groups of healthy children in the UK population. However this does not taken into account potential increased needs of sick children. Probable difficulties in determining standards for sick children are the numerous variables; disease type and stage, age, gender, level of physical activity, ability to absorb and utilise nutrients etc.

This study showed that the majority of children receiving nutritional support (tube feeds and/or food supplements) achieved their RNI intakes for antioxidants, energy and protein. Conversely children on diet alone displayed poor intakes of these nutrients. Further studies will be required to determine the clinical implications of these findings. One hypothesis to be tested would be that children who are receiving optimum nutritional support experience fewer infections, decreased length of stay and fewer dose adjustments to treatment. A large number of children would be needed to investigate this and collaboration of many centres would be required. The clinically useful outcomes, for which such a study should be powered, might include:

1. A reduction in the length of stay per cycle of chemotherapy by $\geq$ one day in the intervention versus non-intervention group

2. A reduction in infections in the intervention group.

3. A reduction in dose adjustments in the intervention group.

Many factors would have to be controlled in such a study such as type of treatment, pre-existing morbidities, nutritional status at outset etc. To our knowledge no study of this nature has been conducted before. 
From this study a recommendation to the local cancer team, would be to devise an educational leaflet for the patient/parents stating the findings of the study, with appropriate means of improving both energy and antioxidant intake to meet the RNI and EAR. This would also include education to the cancer unit team to ensure that the findings of the project are known and that consistent education is provided to parents. A small addition to the nutritional algorithm would be to include the prompt of starting a vitamin-mineral supplement if eating limited fruit and vegetables and at a low nutritional risk and healthy eating if excessive weight gain is seen and consideration of an alternative method of measuring malnutrition for e.g. MUAC especially in children with Solid tumours. This will also raise awareness of the need for consistent growth monitoring and noting any clinical signs of deficiency. Upon forwarding recommendations to the cancer unit team, it would be recommended that the study be repeated to determine whether a greater percentage of children are meeting their $\mathrm{RNI}$ requirements. 


\section{REFERENCES}

1. Ward E. Childhood cancers In: Shaw V, Lawson M, editors. Clinical Paediatric Dietetics. Oxford: Blackwell publishing; 2007. p. 461-72.

2. Sala A, Penchaz P, Barr RD. Children, cancer, and nutrition - a dynamic triangle in review. Cancer. 2004;100(4):677-87.

3. Salganik RI. The benefits and hazards of antioxidants: controlling apoptosis and other protective mechanisms in cancer patients and the human population. JACN. 2001;5:464s$72 \mathrm{~s}$.

4. Donaldson SS, Wesley MN, DeWys WK, Suskind RM, Jaffe N, van Eys J. A study of the nutritional status of paediatric cancer patients. Am J Dis Child. 1981;135(12):1107-12.

5. van Eys J. Malnutrition in children with cancer: incidence and consequence. Cancer. 1979 May;43(5 Suppl):2030-5.

6. Ladas EJ, Jacobson JS, Kennedy DD, Teel K, Fleischauer A, Kelly KM. Antioxidants and cancer therapy: a systematic review. J Clin Oncol. 2004;22(3):517-28.

7. Lobato-Mendizabel E, Ruiz-Arguelles G, Marin-Lopez A. Leukemia and Nutrition: malnutrition is an adverse prognostic factor in the outcome of patients with standard risk. Leuk Res. 1989;13:899-06.

8. Reilly JJ, Weir J, McColl JH, Gibson BES. Prevalence of protein-energy malnutrition at diagnosis in children with Acute lymphoblastic leukemia. J Pediatr Gastroenterol Nutr. 1999;29(2):194-97.

9. Rickard KA, Detamore CM, Coates TD et al. Effect of nutritional staging on treatment delays and outcome in stage IV neuroblastoma. Cancer. 1983;52:587-92.

10. van Eys J. Nutrition in the treatment of cancer in children. J Am Coll Nutr. 1984;3(2):15968.

11. Kennedy DD, Tucker KL, Ladas ED, Rheingold SR, Blumberg J, Kelly KM. Low antioxidant vitamin intakes are associated with increases of adverse effects of chemotherapy in children with Acute lymphoblastic leukaemia. Am J Clin Nutr. 2004;79:1029-36.

12. Skolin I, Axelsson K, Ghannad P, Hernell O, Whalin YB. Nutrient intake and weight development in children during chemotherapy for malignant disease. Oral Oncol. 1997;33(5):364-68.

13. Khan A, Moeen-ul-Haq S, Intekhab K. Does weight for age have prognostic significance in children with Acute lymphoblastic leukaemia. Pak J Med Sci. 2006;22(2):167-70.

14. Kibirige MS, Morris-Jones $\mathrm{PH}$, Stevens RF, Rayner C. Nutrition, infection and morbidity in Leukaemia. Ped Haem Oncol. 1988;5(3):179-85.

15. Brotherton A, Simmonds N, Stroud M. Malnutrition matters - meeting quality standards in nutritional care. A report from the BAPEN Quality Group lead by BAPEN. Redditch; 2010. 
16. Department of Health. Dietary Reference Values for food energy and nutrients for the United Kingdom. London: HMSO; 1999.

17. Combs GF. Vitamins. In: Mahan LK, Escott-Stump S, editors. Krause's food, Nutrition \& Diet Therapy. 10th ed. Philadelphia: W.B Saunders Company; 2000. p. 67-110.

18. Verhagen HB, B.; Jansen, E.; Bueno-de-Mesquita, B. The State of Antioxidant Affairs. Nutr Today 2006;41:244-50.

19. Waris G, Ahsan H. Reactive Oxygen species: role in the development of cancer and various chronic conditions. J Carcinogenesis. 2006;5(4):1-8.

20. Conklin KA. Dietary antioxidants during cancer chemotherapy: impact on chemotherapeutic effectiveness and development of side effects. Nutr Cancer. 2000;37(1):1-18.

21. The Johns Hopkins University Evidence-based Practice Center. Evidence Report/Technology Assessment. Multivitamin/mineral supplements and prevention of chronic disease In: US Department of Health and Human Services, editor. Baltimore: US Department of Health and Human Services; 2006. p. 1-321.

22. Koller LD, Exon JH. The two faces of selenium-deficiency and toxicity are similar in animals and man. Can J Vet Res 1986;50:297-06.

23. Zeisal HS. Free radicals: the pros and cons of antioxidants. ASNS. 2004;134(November):3179S-80S.

24. Salganik RI, Albright CD, Rodgers J, Kim J, Zeisel SH, Sivashinskiy MS, et al. Dietary antioxidant depletion: enhancement of tumor apoptosis and inhibition of brain tumor growth in transgenic mice Carcinogenesis. 2000;21(5):909-14.

25. Gabriella M, D'Andrea MD. Use of antioxidants during chemotherapy and radiotherapy should be avoided. CA Cancer J Clin 2005;55:319-21.

26. Malvy D, Arnaud J, Burtschy B, Sommelet D, Leverger G, Dostalova L, et al. Antioxidant micronutrients and childhood malignancy during oncological treatment. Med Pediatr Oncol. 1997 Sep;29(3):213-7.

27. Ratman DV, Ankola DD, Bhardwaj V, Sahana D, Kumar MN. Role of antioxidants in prophylaxis and therapy: a pharmaceutical perspective. $\mathrm{J}$ Control Release. 2006;20(113):67-90.

28. Conklin KA. Cancer chemotherapy and antioxidants. J Nutr 2004;134(Nov):3201s-4s.

29. Hall E. Repair of radiation damage and the dose-rate effect. In: John JRS, P.; Marino, D., editor. Radiobiology for the Radiologist. 5th ed. Philadelphia: Lippincott Williams and Wilkins; 2000. p. 67-90.

30. Malvy D, Burtschy B, Arnaud J, Sommelet D, Leverger G, Dostalova L, et al. Serum betacarotene and antioxidant micronutrients in children with cancer. The 'Cancer in Children and Antioxidant Micronutrients' French Study Group. Int J Epidemiol. 1993 Oct;22(5):76171. 
31. Koskelo EK. Serum selenium in children during anti-cancer treatment. Euro J Clin Nutr. 1990;44(11):799-02.

32. Postovsky S, Arush M, Diamond E, Elhasid R, Shoshani G, Shamir. The prevalence of low selenium levels in newly diagnosed pediatric cancer patients. Ped Haem Oncol. 2003;20(4):273-80.

33. Koskelo EK, Saarinen UM, Siimes MA. Low levels of serum transport proteins indicate catabolic protein status during induction therapy for Acute lymphoblastic leukaemia Pediatr Hematol Oncol. 1991;8:53-9.

34. Cavdar AO, Babacan E Gozdasoglu S, Yavuz G, Mengubas K, Pamir A and Tacyildiz N. Trace element analyses (Zinc and Selenium) in pediatric malignant Lymphomas. Turk $\mathrm{J}$ Haem. 2002;19(2):239-44.

35. Gokhale CD, Udipi SA, Ramkrishna AY, Suresh PK, Suresh AH. Post-therapy profile of serum total cholesterol, retinol and zinc in pediatric Acute lymphoblastic leukaemia and non-Hodgkins Lymphoma. JACN. 2007;26(1):49-56.

36. Reilly JJ, Weir J, McColl JH, Gibson BES. Prevalence of protein-energy malnutrition at diagnosis in children with Acute lymphoblastic leukemia. J Pediatr Gastroenterol Nutr. 1999;29(2):194-97.

37. Picton SV. Aspects of altered metabolism in children with cancer. Int J Can. 1998(Suppl 11):62-4.

38. Tisdale, M.J. Cancer Cachexia; metabolic alterations and clinical manifestations. Nutrition. 1997;13:1-7.

39. Andrassy RJ, Chwals WJ. Nutritional support of the pediatric oncology patient. Nutrition. 1998 Jan;14(1):124-9.

40. Rossi-Fanelli F, Cascino A, Muscaritoli M. Abnormal substrate metabolism and nutritional strategies in cancer management. J Parenter Enteral Nutr. 1991 Nov-Dec;15(6):680-3.

41. Rickard KA, Thomas D, Coates MD, Jay L, Grosfeld MD, Robert M, et al. The value of nutrition support in children with cancer. Cancer. 1986;52:587-90.

42. Rickard KA, Grosfeld JL, Coates TD, Weetman R, Baehner RL. Advances in nutrition care of children with neoplastic diseases: a review of treatment, research, and application. $\mathrm{J}$ Am Diet Assoc. 1986;86(12):1666-76.

43. de Onis M. Child growth and development. In: Semba RD, Bloem MW, editors. Nutrition and health in developing countries. 2nd ed. Totowa: Humana Press; 2008. p. 113-17.

44. de Onis M, Blossner M. WHO global database on child growth and malnutrition. In: WHO, editor. Geneva; 1997. p. 1-67.

45. El-Mantary W. Percutaneous endoscopic gastrostomy in children. Can J Gastroenteral. 2008;12(22):993-98.

46. Costlow N. Nutrition oncology nutrition support In: Bloch A, editor. Nutrition management of the cancer patient. United States of America: Apen publishers; 1990. p. 135-39. 
47. Sala A, Wade L, Barr RD. Nutritional support for children with cancer. Indian J Pediatr. 2003 Oct;70(10):813-6.

48. Jeejeebhoy K. Total parenteral nutrition: potion or poison. Am J Clin Nutr. 2001.;74(2):16063.

49. Copeman MC. Use of total parenteral nutrition in children with cancer: a review and some recommendations. Pediatr Hematol Oncol. 1994 Sep-Oct;11(5):463-70.

50. Christensen ML, Hancock ML, Gattuso J, Harwitz CA, Smith C, McCormick J, et al. Parenteral nutrition associated with increased infection rate in children with cancer. Cancer. 1993;72(9):2732-8.

51. Ward E, Hopkins M, Arbuckle L, Williams N, Forsythe L, Bujkiewicz S, et al. Nutritional problems in children treated for Medulloblastoma: implications for enteral nutrition support. Pediatr Blood Cancer. 2009;53:570-75.

52. Aquino VM, Smyrl CB, McHard KM, Hagg R, Prestridge L, Sandler ES. Enteral nutritional support by gastrostomy tube in children with cancer. J Pediatri. 1995;128(1):58-62.

53. Bisgaard-Pederson AM, Kok K, Petersen G, Nielsen OH, Michaelsen KF, Schmiegelo W. Percutaneous endoscopic gastrostomy in children with cancer. Acta Paediatrica. 1999;88(8):849-52.

54. Joint Food and Agriculture Organization. Joint Food and Agriculture Organization of the United Nations/World Food Organization of the United Nations Expert Consultation on Human Vitamin and Mineral requirements In: Organization FaA, editor. Bangkok; 1998.

55. Gibson RS. Principles of nutritional assessment. 2nd ed. Oxford: Oxford University Press; 2005.

56. Lee RD, Nieman DC. Nutritional assessment. London: McGraw-Hill; 2003.

57. Nelson M, Margetts M. Design, planning and evaluation of nutritional epidemiological studies. In: Nelson M, Bingham SA, editors. Design concepts in nutritional epidemiology. 2nd ed. Oxford: Oxford Medical Publications; 2006. p. 123-69.

58. Rutishauser IH, Black AE. Measuring Food Intake In: Gibney MJ, Vorster HH, Kok FJ, editors. Introduction to human nutrition Oxford: Blackwell Science; 2002. p. 225-48.

59. Fish and Food Ministry of Agriculture. Standard Manual on food portions and household measures in the United Kingdom. In: Crawley, H, editor. Maff Handbook. Stationery Office Books; Feb 1994.

60. World Health Organization. Training course on child growth assessment: Interpreting growth indicators. In: Department of Nutrition for Health and Development, editor. Geneva: WHO Press; 2008.

61. Department of Health. Dietary Reference Values for food energy and nutrients for the United Kingdom. London: HMSO; 1999.

62. Van Teijlingen ER, Hundley V. The importance of pilot studies. Journal [serial on the Internet]. 2001 Date; (35). 
63. Palaniappan U, Cue RI, Payette H, Gray Donald K. Implications of day-to-day variability on measurement of usual food and nutrient intake. J Nutr. 2003;133:232-5.

64. Maclntyre UE. Measuring food intake. In: Gibney MJ, Hester H, Vorster, Kok FJ, editors. Introduction to human nutrition. 2nd ed. Chichester: Wiley-Blacknell; 2009. p. 238-75.

65. Garofolo A, Lopez FA, Petrilli AS. High prevalence of malnutrition among patients with solid non-hematological tumors as found by using skinfold and circumference measurements. Sao Paulo Med J. 2005;123(6):1516-3180.

66. Bauer J, Jurgens H, Fruhwald MC. Important aspects of nutrition in children with cancer. Adv Nutr. 2011;2:67-77.

67. Bechard LJ, Duggan C. Cancer treatment. In: Duggan C, Watkins JB, Walker WA, editors. Nutrition Paediatrics 4. Onario: BC Decker Inc; 2008. p. 607-16.

68. Mayer EL, Reuter M, Dopfer RE, Ranke MB. Energy expenditure, energy intake and prevalence of obesity after therapy for Acute lymphoblastic leukemia during childhood. Horm Res. 2000;53(4):193-9.

69. Reilly JJ, Ness AK, Dorosty AR, Hamish W, Wallace B, Gibson BE, et al. Premature adiposity rebound in children treated for acute lymphoblastic leukaemia. J Clin Endocrinol Metab. 2001;86(6):2775-78.

70. Gerasimidisa K, Keane O, Macleod I, Flynn DM, Wright CW. A four-stage evaluation of the Paediatric Yorkhill Malnutrition Score in a tertiary paediatric hospital and a district general hospital. Brit J Nutr. 2010;104(5):751-56.

71. Scrimshaw NS, Schurch B. Protein-energy interactions. Proceedings of an IDECG workshop. Waterville Valley, NH; 1991.

72. Golden, HG. Proposed recommended nutrient densities for moderately malnourished children. Food Nutr Bull. 2009;30:S267-342S.

73. Macdonald RS. The role of zinc in growth and cell proliferation. J Nutr. 2000;130(5S suppl):1500S-8S.

74. Nish Y. Zinc and growth. JACN. 1996;15(4):340-44.

75. Rising R, Scaglia JE, Cole C, Tverskaya R, Duro D, Lifshitz F. Exogenous recombinant human growth hormone effects during suboptimal energy and zinc intake. Nutr Metab. Lond). 1997:2(10).

76. Wolbach SB. Vitamin A deficiency and excess in relation to skeletal growth. J Bone Joint Surg Am 1947;29:171-92.

77. Michaelsen KF, Sandstrom BM. Summary of recommendations from the Nordic countries. Fredriksberg, Denmark: Research Department of Human Nutrition, the Royal Veterinary and Agricultural University; 1994.

78. Kelly KM, Jacobson JS, Kennedy DD, Braudt SM, Mallick M, Weiner MA. Use of unconventional therapies by children with cancer at an urban medical center. J Pediatr Hematol Oncol. 2000;22(5):412-6. 
79. Bussieres J, Theoret Y, Lebel D, Kish S, Moghrabi A, Laurier C. Use of complementary therapies in children with cancer. Paed Blood Can. 2005;44:660-68.

80. Mottonen M, Uhari M. Use of micronutrients and alternative drugs by children with Acute lymphoblastic leukemia. Med Pediatr Oncol. 1997;28(3):205-8.

81. Neuhouser ML, Patterson RE, Schwartz SM, Hedderson MM, Bowen DJ, Standish LJ. Use of alternative medicine by children with cancer in Washington State. Prev Med. 2001;33(5):347-54.

82. WHO. Global prevalence of vitamin A deficiency in populations at risk 1995-2005. WHO Global Database on Vitamin A Deficiency. Geneva: World Health Organization; 2009.

83. Briony T. Manual of dietetic practice. 3rd ed. British Dietetic Association, editor. Oxford: Blackwell; 2001.

84. Traber MG. Vitamin E. In: Shils ME, Shike M, Ross AC, Caballero B, Cousins R, editors. Modern nutrition in health and disease. 10th ed. Baltimore: Lippincott Williams \& Wilkins; 2006. p. 396-11.

85. Goldhaber SB. Trace element risk assessment: essentiality vs. toxicity. Regul Toxicol Pharm. 2003;38:232-42.

86. Rayman MP. The importance of selenium to human health. Lancet. 2000;356(9225):23341.

87. Anderson JB. Minerals. In: Mahan LK, Escott-Stump S, editors. Krause's Food, Nutrition \& Diet Therapy. Pennsylvania: W.B. Saunders Company; 2000. p. 110-52. 


\section{ADDENDA}

Addendum A: Summary of each antioxidants function, source, nutritional state and requirement

\begin{tabular}{|c|c|c|c|c|}
\hline Antioxidant & Functions & Nutritional State & Sources & Requirement \\
\hline Vitamin A & $\begin{array}{l}\text { Essential for normal } \\
\text { development and } \\
\text { differentiation of tissues. }{ }^{(17,} \\
\text { 82) }\end{array}$ & $\begin{array}{l}\text { - Excessive intakes of retinol cause liver } \\
\text { and bone damage, hair loss, double } \\
\text { vision, vomiting, headaches and other } \\
\text { abnormalities } \\
\text { - Vitamin A deficiency common in } \\
\text { developing countries } \\
\text { - Obvious signs of deficiency are dryness } \\
\text { of conjunctiva and cornea Can lead to } \\
\text { permanent eye damage } \\
\text { - Primary deficiency - characterized by } \\
\text { impaired embryonic development, } \\
\text { impaired spermatogenesis, } \\
\text { spontaneous abortion, impaired } \\
\text { immune competence. } \\
\text { - Secondary deficiency - results from } \\
\text { malabsorption due to insufficient dietary }\end{array}$ & $\begin{array}{l}\text { Pre-formed vitamin } \\
\text { A i.e. liver, milk } \\
\text { and eggs } \\
\text { - Pro-vitamin A i.e. } \\
\text { dark green leafy, } \\
\text { and yellow-orange } \\
\text { vegetables and } \\
\text { fruit } \\
\text { Cod, halibut } \\
\text { (very high } \\
\text { concentration) } \\
\text { (16,17) }\end{array}$ & $\begin{array}{l}\text { Regular intakes should } \\
\text { not exceed: } \\
\text { 1800ug (1-3years old) } \\
\text { 3000ug (4-6years old) } \\
\text { 4500ug (6-12years old) } \\
6000 \text { ug (adolescents) } \\
\text { See DRV in Addendum } \\
\text { B }\end{array}$ \\
\hline
\end{tabular}




\begin{tabular}{|c|c|c|c|c|}
\hline Antioxidant & Functions & Nutritional State & Sources & Requirement \\
\hline & & $\begin{array}{l}\text { fat, biliary, or pancreatic insufficiency } \\
\text { - Prolonged deprivation leads to death }{ }^{(16,} \\
17,82,83)\end{array}$ & & \\
\hline Vitamin C & $\begin{array}{l}\text { - Prevents scurvy and aids } \\
\text { wound healing } \\
\text { - Assists absorption of non- } \\
\text { haem-iron } \\
\text { - Important antioxidant }{ }^{(16)}\end{array}$ & $\begin{array}{l}\text { - Excessive intakes of grams/day lead to } \\
\text { increased production of kidney stones } \\
\text { (oxalate predominant) } \\
\text { - Frank deficiency (scurvy) rarely seen in } \\
\text { UK } \\
(16,83)\end{array}$ & $\begin{array}{l}\text { - Citrus and soft } \\
\text { fruits, growing } \\
\text { points of } \\
\text { vegetables }^{(17)}\end{array}$ & $\begin{array}{l}\text { See DRV in Addendum } \\
\text { B }\end{array}$ \\
\hline Vitamin E & $\begin{array}{l}\text { - Principal function as } \\
\text { antioxidant (especially in } \\
\text { lipid soluble } \\
\text { membranes) }{ }^{(84)}\end{array}$ & $\begin{array}{l}\text { - Few adverse effects from doses up to } \\
3200 \mathrm{mg} / \text { day (not consistently seen) } \\
\text { - Clinical manifestations of deficiency } \\
\text { vary. In general targets neuromuscular, } \\
\text { vascular, and reproductive systems } \\
\text { - Clinical deficiency is rare and only } \\
\text { clearly identified in premature infants }{ }^{(17} \text {, } \\
20,83)\end{array}$ & $\begin{array}{l}\text { - Nuts, seeds, and } \\
\text { vegetable oils, } \\
\text { green leafy } \\
\text { vegetables and } \\
\text { fortified cereals }\end{array}$ & $\begin{array}{l}\text { S } \\
\text { safety of high levels to } \\
\text { be established } \\
\text { (Addendum B) }\end{array}$ \\
\hline
\end{tabular}




\begin{tabular}{|c|c|c|c|c|}
\hline Antioxidant & Functions & Nutritional State & Sources & Requirement \\
\hline Selenium & 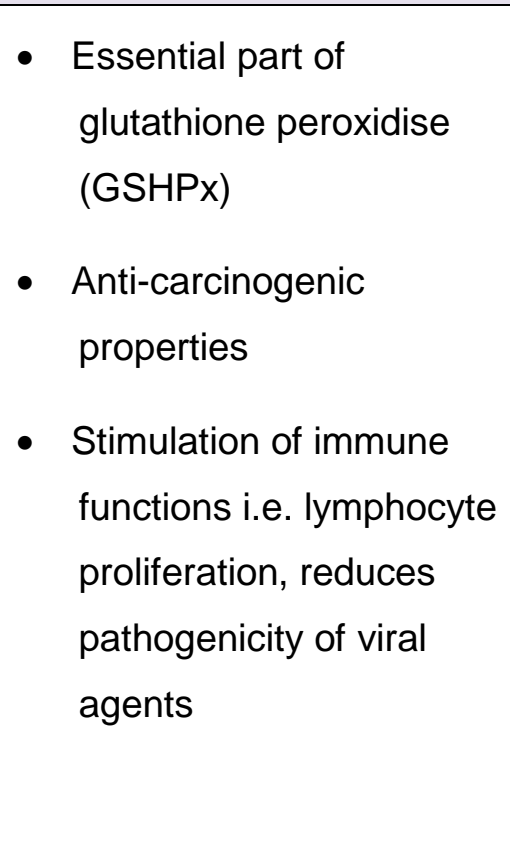 & $\begin{array}{l}\text { - Levels in excess of } 100 \mathrm{ug} / \mathrm{dL} \text { lead to } \\
\text { selenosis. Symptoms include: hair loss, } \\
\text { white blotchy nails, fatigue, irritability, } \\
\text { mild nerve damage, gastrointestinal } \\
\text { upsets } \\
\text { - Deficiency rare in humans and may take } \\
\text { years to develop. Repletion occurs } \\
\text { within weeks or months } \\
\text { - Considerable interaction occurs between } \\
\text { selenium and vitamin E. If high doses of } \\
\text { Vitamin E are ingested, this decreases } \\
\text { the effects of selenium deficiency }{ }^{(83,85)}\end{array}$ & $\begin{array}{l}\text { - Cereals, seafood, } \\
\text { meat } \\
\text { - Concentration of } \\
\text { selenium in food } \\
\text { dependent } \\
\text { selenium content } \\
\text { of soil an soil type } \\
\text { Vegetables, fruits } \\
\text { and beverages } \\
\text { are generally low } \\
\text { in selenium }{ }^{(83,86)}\end{array}$ & $\begin{array}{l}\text { - Margin between } \\
\text { selenium } \\
\text { requirement and } \\
\text { deficiency narrower } \\
\text { than most trace } \\
\text { elements; therefore } \\
\text { high risk of toxicity in } \\
\text { over- } \\
\text { supplementation }{ }^{(83)} \\
\text { See DRV in Addendum } \\
\text { B }\end{array}$ \\
\hline
\end{tabular}




\begin{tabular}{|c|c|c|c|c|}
\hline Antioxidant & Functions & Nutritional State & Sources & Requirement \\
\hline Zinc & $\begin{array}{l}\text { Structural, catalytic, regulatory } \\
\text { role in many enzymes } \\
\text { - Structural role in non- } \\
\text { enzymatic proteins } \\
\text { - Maintains configuration of } \\
\text { mammalian gene } \\
\text { transcription proteins and } \\
\text { integrity of biomembranes } \\
\text { - Involved in major metabolic } \\
\text { pathways for the } \\
\text { metabolism of protein, } \\
\text { carbohydrate, energy, } \\
\text { nucleic acids and lipids }{ }^{(16)}\end{array}$ & $\begin{array}{l}\text { Chronic ingestion of } 75-300 \mathrm{mg} / \mathrm{day} \text { (1.15- } \\
4.59 \mathrm{mmol} / \mathrm{d} \text { ) associated with copper } \\
\text { deficiency features i.e. microcytic anaemia, } \\
\text { neutropenia. } \\
\text { - Short term studies show } 50 \mathrm{mg} \\
\quad(0.76 \mathrm{mmol}) \text { interferes with metabolism of } \\
\text { iron and copper } \\
\text { - Overt deficiency rare } \\
\text { - Subclinical deficiency common } \\
\text { especially with tissue injury, surgery, } \\
\text { infection, low dietary intake (eating and } \\
\text { swallowing difficulties). }{ }^{(16,83)}\end{array}$ & $\begin{array}{l}\text { Meat, fish, poultry, } \\
\text { milk and milk products } \\
\text { - Fairly good } \\
\text { sources } \\
\text { oysters, } \\
\text { cheese, } \\
\text { wholegrain } \\
\text { cereals, dry } \\
\text { bean, nuts } \\
\text { - Body dependent } \\
\text { on regular } \\
\text { dietary supply } \\
\text { (no specific } \\
\text { zinc reserve). } \\
\text { (87) }\end{array}$ & $\begin{array}{l}\text { See DRV in Addendum } \\
\text { B }\end{array}$ \\
\hline
\end{tabular}


ADDENDUM B: Dietary reference values for vitamin A, C, selenium and zinc and safe intake for vitamin $\mathrm{E}$

Dietary reference value for vitamin A (ug retinol equivalent/day) $)^{(16)}$

\begin{tabular}{|l|c|c|c|}
\hline Age (years) & $\begin{array}{c}\text { Lower Reference } \\
\text { Nutrient Intake }\end{array}$ & $\begin{array}{c}\text { Estimated Average } \\
\text { Requirement. }\end{array}$ & Reference Nutrient Intake \\
\hline $1-3$ & 200 & 300 & 400 \\
$4-6$ & 200 & 300 & 400 \\
$7-10$ & 250 & 350 & 500 \\
Males & & & \\
$11-14$ & 250 & 400 & 600 \\
$15-18$ & 300 & 500 & 700 \\
& & & \\
Females & 250 & 400 & 600 \\
$11-14$ & 300 & 400 & 600 \\
$15-18$ & & & \\
\hline
\end{tabular}

Dietary reference value for vitamin C $(\mathrm{mg} / \text { day })^{(16)}$

\begin{tabular}{|l|c|c|c|}
\hline Age (years) & $\begin{array}{c}\text { Lower Reference } \\
\text { Nutrient Intake }\end{array}$ & $\begin{array}{c}\text { Estimated Average } \\
\text { Requirement }\end{array}$ & Reference Nutrient Intake \\
\hline $1-3$ & 8 & 20 & 30 \\
$4-6$ & 8 & 20 & 30 \\
$7-10$ & 8 & 20 & 30 \\
Males & & & \\
$11-14$ & 9 & 22 & 35 \\
$15-18$ & 10 & 25 & 40 \\
& & & \\
Females & 9 & 22 & 35 \\
$11-14$ & 10 & 25 & 40 \\
$15-18$ & & & \\
\hline
\end{tabular}

Dietary reference values for selenium (ug/day) ${ }^{(16)}$

\begin{tabular}{|l|c|c|}
\hline \multicolumn{1}{|c|}{ Age (years) } & $\begin{array}{c}\text { Lower Reference Nutrient } \\
\text { Intake }\end{array}$ & Reference Nutrient Intake \\
\hline $1-3$ & $7(0.1)$ & $15(0.2)$ \\
$4-6$ & $10(0.1)$ & $20(0.3)$ \\
$7-10$ & $16(0.2)$ & $30(0.4)$ \\
$11-14$ & $25(0.3)$ & $45(0.6)$ \\
Males & $40(0.5)$ & $70(0.9)$ \\
$15-18$ & $40(0.5)$ & $60(0.8)$ \\
Female & & \\
$15-18$ & & \\
\hline
\end{tabular}


Dietary reference values for zinc (mg/day) ${ }^{(16)}$

\begin{tabular}{|l|c|c|c|}
\hline Age (years) & $\begin{array}{c}\text { Lower Reference } \\
\text { Nutrient Intake }\end{array}$ & $\begin{array}{c}\text { Estimated } \\
\text { Average } \\
\text { Requirement }\end{array}$ & Reference Nutrient Intake \\
\hline $1-3$ & $3.0(45)$ & $3.8(60)$ & $5.0(75)$ \\
$4-6$ & $4.0(60)$ & $5.0(75)$ & $6.5(100)$ \\
$7-10$ & $4.0(60)$ & $5.4(80)$ & $7.0(110)$ \\
Males & & & \\
$11-14$ & $5.3(80)$ & $7.0(110)$ & $9.0(140)$ \\
$15-18$ & $5.5(85)$ & $7.3(110)$ & $9.5(145)$ \\
& & & \\
Females & & $7.0(110)$ & $9.0(140)$ \\
$11-14$ & $5.3(80)$ & $5.5(85)$ & $7.0(110)$ \\
\hline $15-18$ & $4.0(60)$ & & \\
\hline
\end{tabular}

Safe intake for vitamin E (mg $\alpha$-tocopherol equivalent/day)

\begin{tabular}{|l|c|}
\hline \multicolumn{1}{|c|}{ Age (years) } & Vitamin E (mg $\boldsymbol{\alpha}$ tocopherol) \\
\hline Males & \\
1-3 years & 3.2 \\
4-6years & 4.9 \\
7-10years & 5.6 \\
11-14years & 6.4 \\
15-18years & 8.0 \\
\hline Female & \\
1-3 years & 3.2 \\
4-6years & 4.3 \\
7-10years & 5.0 \\
11-14years & 5.3 \\
15-18years & 6.1 \\
\hline
\end{tabular}


ADDENDUM C: Estimated Average Requirements for energy and protein ${ }^{(16)}$

\begin{tabular}{|l|c|c|}
\hline \multicolumn{1}{|c|}{ Age (years) } & Energy (kcal) & Protein (g) \\
\hline Males & 1230 & \\
$1-3$ & 1715 & 14.5 \\
$4-6$ & 1970 & 19.7 \\
$7-10$ & 2220 & 28.3 \\
$11-14$ & 2755 & 42.1 \\
$15-18$ & & 55.2 \\
\hline Female & 1165 & \\
$1-3$ & 1545 & 14.5 \\
$4-6$ & 1740 & 19.7 \\
$7-10$ & 1845 & 28.3 \\
$11-14$ & 2110 & 41.2 \\
$15-18$ & & 45.4 \\
\hline
\end{tabular}


ADDENDUM D: Safe Upper intake for vitamin A and E

Safe Upper Intakes for vitamin A (ug retinol equivalents/day) should not exceed: ${ }^{(16)}$

\begin{tabular}{|l|c|}
\hline \multicolumn{1}{|c|}{ Age (years) } & $\begin{array}{c}\text { Vitamin A(ug retinol } \\
\text { equivalents/day) }\end{array}$ \\
\hline Infants & 900 \\
$1-3$ & 1800 \\
$4-6$ & 3000 \\
$6-12$ & 4500 \\
Adolescents & 6000 \\
\hline
\end{tabular}

Safe Upper Intake for vitamin E (mg $\alpha$-tocopherol equivalent/day $)^{(16)}$

Few adverse effects have been reported from doses of vitamin $E$ up to $3200 \mathrm{mg} /$ day 
ADDENDUM E: Invitation letter to study

\author{
Department of Nutrition and Dietetics \\ Box 119
}

Tel: 01223216655

Fax: 01223216824

Addenbrooke's NHS Trust

Hills Road

Cambridge CB2 2QQ

Tel: 01223245151

www.addenbrookes.org.uk

\title{
DEAR PARENT/CARER AND CHILD
}

As part of my Master in Nutrition, I hereby invite you to participate in a research project that is currently underway at the University of Stellenbosch, South Africa. The research topic being researched is: Antioxidant Intake in Paediatric Oncology Patients.

This research study has been approved by the Hertfordshire Research Ethics Committee, England (project nr: 08/H0311/53) and by the Committee for Human Research, Faculty of Health Sciences, Stellenbosch University, South Africa (project nr: N08/04/094).

There is widespread interest in the role that antioxidants play in the prevention and course of cancer treatment. There is very little data available on the nutritional requirements for antioxidants in children and much is extrapolated/taken from work done in adults. There are two particular schools of thought about antioxidants and cancer treatment; i.e. Antioxidants play a beneficial role in improving cancer treatment tolerance, reduce infections and less frequent delays in treatment occur, whereas the other school of thought is that antioxidants may interfere with the efficacy of certain cancer treatments.

In this study we will be determining if your child's antioxidant intake is meeting the recommended nutrient intake for antioxidants as recommended by the Department of Health.

To determine your child's antioxidant intake, would you be willing to complete two 4-day Food Records (issued within first month after diagnosis and three months later)? The Primary Investigator, Sonja Slegtenhorst will provide you with the Food Records and a date to start recording in the Food Record. This will enable us to determine your child's antioxidant intake at different periods of the treatment. The week prior to starting the Food Record the Primary Investigator will call you by telephone (on the Monday, Wednesday, Friday and Sunday) to recall your child's previous $24-\mathrm{hr}$ recall of food and fluid intake. These telephone calls will be of a short duration and will serve to validate/reference the Food Record.

Participation in this study is voluntary and patients are able to withdraw without this affecting their treatment. Any information gathered would be useful in contributing to current dietetic practice and has the potential to improve nutritional management of the paediatric cancer patient.

\section{How to reply:}

Please complete the 4-day Food Record and return it in the prepaid envelope to:

Sonja Slegtenhorst

BOX 119. Addenbrookes Hospital, Nutrition and Dietetic Department.

Hills Road. Cambridge

CB2 OQQ

Your participation is greatly appreciated. Should you have any queries with regard to this research study or the completion of the food record please contact Sonja Slegtenhorst at tel: 01223216655

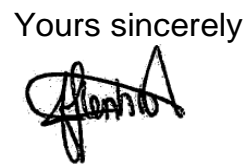

Sonja Slegtenhorst

Paediatric Dietitian 
Please ask if you require this information in other languages, large print or audio format: 01223216032 or patient.informationeaddenbrookes.nhs.uk Informacje te można otrzymać $w$ innych językach, w wersji dużym drukiem lub audio. Zamówienia prosimy składat pod numerem: 01223216032 lub

wysylając e-mail: patientinformation@addenbrookes.nhs ulk
Polish

Se precisar desta informaçăo num outro idioma, em impressắo

de letras grandes ou formato ádio por favor telefone para o 01223 216032 ou envie uma mensagem para:

\section{Portuguese}

Если вам требуется эта информация на другом языке, крупным

шрифтом или в аудиоформате, пожалуйста, обращайтесь по телефон 01223216032 или на вебсайт patient, informationeaaddentrookes.nhs, uk

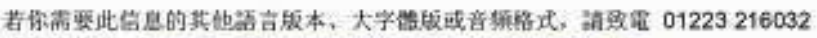

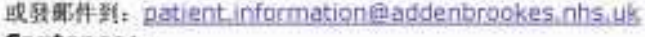

Cantonese

Bu bilgivi diger dillerde veya büyük baskill ya da sesli formatta

veya asagidaki adrese e-posta gonderin:

Turkish

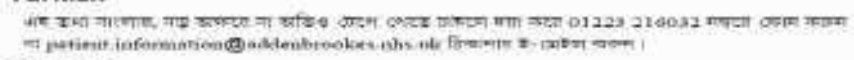

Bengali

Addenbrooke's is smoke-free. Please do not smoke anywhere on the site. For advice on quitting, contact your GP or the NHS smoking helpline free,

Document history

\begin{tabular}{|c|c|c|c|}
\hline \\
\hline \multicolumn{4}{|c|}{\begin{tabular}{|l|l} 
Authors & Sonja Slegtenhorst
\end{tabular}} \\
\hline Department & Children's Services & Contact no & 01223348223 \\
\hline Published & 28.05 .09 & Review date & May-11 \\
\hline File name & $\begin{array}{l}\text { Whtso4tdatalChildrens } \\
\text { Information Yppi_1742. }\end{array}$ & $\begin{array}{l}\text { ricesspaed QAVP } \\
\text { intioxidant intal }\end{array}$ & $\begin{array}{l}\text { ient } \\
\text { unde }\end{array}$ \\
\hline Version number & 4 & Ref & 1742 \\
\hline
\end{tabular}

* This leaflet is to be shown/read to the child by the parent/carer 
When you're not feeling well

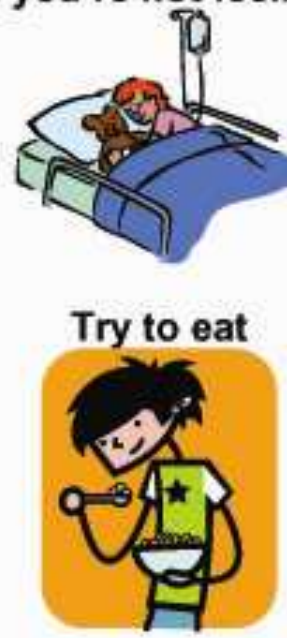

small pieces of good food, like fruit....
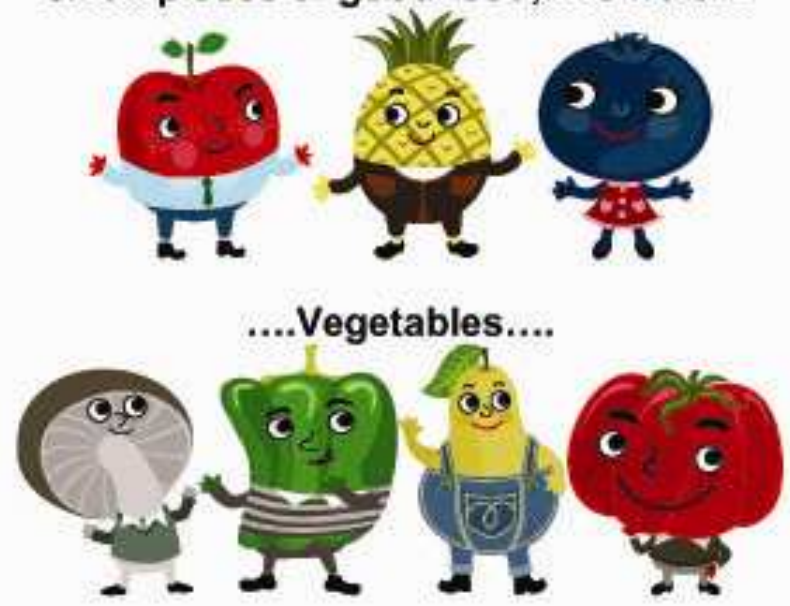

Comparison of antioxidant intake $<5 y r s$ (PPI1742 v4)
....Meat, chicken, fish and bread or pasta

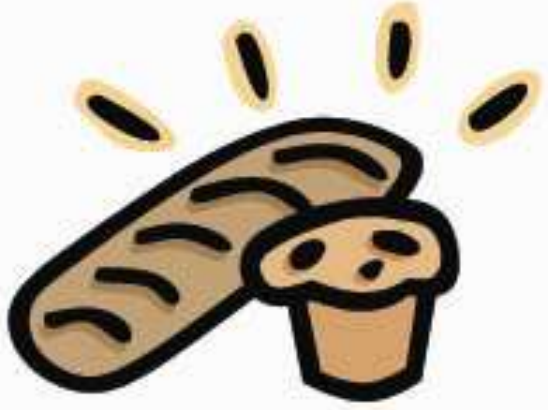

This will make you feel better and stronger!

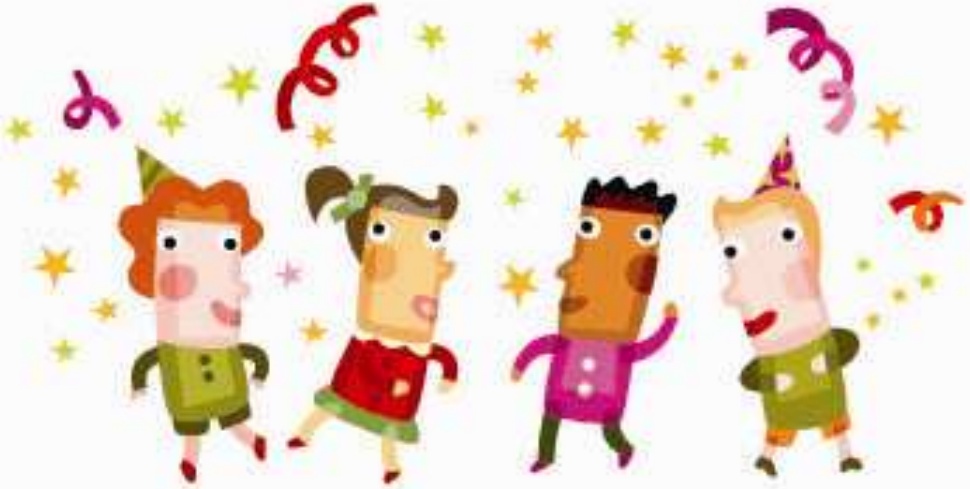

Thank you for reading this with your mum and dad

Comparison of antioxidant intake $<5 y r s$ (PPI1742 v4) Page 3 of 4 
Please ask if you require this information in other languages, large print or audio format: 01223216032 or patient informationeaddenbrookes.nhs uk

Informacje te można otrzymać $w$ innych językach, w wersji dużym drukiem lub audio. Zamówienia prosimy składac pod numerem: 01223216032 lub wysylając e-mail: patientinformationgeddentrockes.nhs ulk

Polish

Se precisar desta informaçăo num outro idioma, em impressăo

de letras grandes ou formato ádio por favor telefone para o 01223

216032 ou envie uma mensagem para:

patient, informationimaddenbrookes.nhs. ubs

Portuguese

Если вам требуется эта информация на другом языке, крупным

шрифтом или в аудиоформате, пожалуйста, обращайтесь по телефону

01223216032 или на вебсайт рatient. informationgliddenbrogkes. nhs.uk. Russian

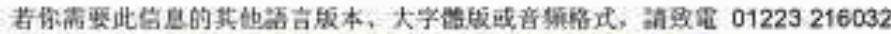

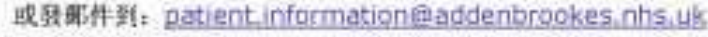

Cantonese

Bu bilgiyi diger dillerde veya büyük baskill ya da sesli formatta

isterseniz latfen su numaradan kontak kurun: 01223216032

veya asagidaki adrese e-posta gonderin:

patient informationeaddenbrookes,ahs, uk

Turkish

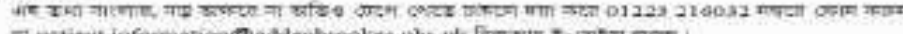

Bengalí

Addenbrooke's is smoke-free. Please do not smoke anywhere on the site. Addenbraoke's is smoke-free. Please do not smoke anywhere on the site.
For advice on quilting, contact your GP or the NHS smoking helpline free, 08001690169

\begin{tabular}{|c|c|c|c|}
\hline \multicolumn{4}{|c|}{ Document history } \\
\hline Authors & \multicolumn{3}{|l|}{ Sonja Slegtenhorst } \\
\hline Department & Children's Services & Contact no & 01223348223 \\
\hline Published & 16.06 .2009 & Review date & June-11 \\
\hline File name & \multicolumn{3}{|c|}{ 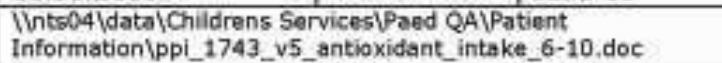 } \\
\hline Version number & 5 & Ref & 1743 \\
\hline
\end{tabular}

Comparison of antioxidant intake 6-10yrs (PPI1743 v5) Page 4 of 4

\section{Antioxidant intake in paediatric oncology patients}

\section{Participant information sheet for children $6-10$ years of age}


You are being invited to take part in a research study. Research is a way to try and find out answers to questions. We want to see if what you eat and drink through treatment gives you enough vitamins and minerals.

\section{What question is the study asking?}

The study is trying to find out whether what you eat and drink during treatment is giving you enough vitamins and minerals. The ones we are specifically looking at are vitamin $A, E, C$, zinc and selenium. You may have learnt about these in school. They are found in a wide range of foods for example fruit and vegetables, meat/chicken/fish etc. These specific vitamins and minerals help your bodys cells repair and helps you to feel better through treatment.

\section{Why have I been chosen to take part?}

Each child that is newly diagnosed with cancer will be invited to take part in this study.

\section{What will happen to me if I take part in the research?}

I have asked your mum and dad to keep a food record for 4 days on what you eat and drink. It is important that all these food items are written down. You can help with this if you want to. Your parents will also write down any tube feeds or special drinks you are having.

The Dietitian will then look at this food record and work out whether you are getting enough vitamins and minerals in your diet. If you are not getting enough or too many vitamins and minerals, your dietitian will talk to you about how to correct this.

\section{Do I have to take part in the study?}

Of course not. If you and your parents decide that you don't want to take part, the doctors at the hospital will still take care of you.

Comparison of antioxidant intake 6-10yrs (PPI1743 v5)

\section{Will joining in the study help me?}

Once the dietitian has worked out if you are getting enough vitamins and minerals, they will give you the results. If they see that you aren't having enough or too many vitamins and minerals, they will talk to you about how to correct this. This will help your body repair its cells better and help you feel better through treatment. This will also help any of your friends or other children that get the same iliness in that we can give good advice on how to meet their needs for vitamins and minerals.

\section{What if I don't want to do the research any more?}

If at any time you don't want to do the research any more just tell your parents, dietitian, nurse or doctor. They will not be cross with you.

\section{Who will know about me taking part in this study?}

The only people who will know what you are taking part in this study will be the team of doctors and the dietitian looking after you.

\section{Did anyone else check the study is ok to do?}

Before any research is allowed to happen it has to be checked by a group of people called a Research Ethics Committee. They make sure that the research is fair. The Hertfordshire Research Ethics Committee and the University of Stellenbosch Ethics Committees have checked the project.

\section{What will happen to the results of the study?}

The results of this study will be looked at regularly. When the study is finished in 1 year's time, the results will be given to you. The results may be printed in a special sort of magazine for Dietitians and Doctors.

Thank you for listening to this or reading it with your mum or dad. If there is anything that you do not understand or which frightens you, do not be afraid to ask Mum or Dad or the Dietitian who is looking after you.

Comparison of antioxidant intake 6-10yrs (PPI1743 v5)

Page 3 of 4 
Please ask if you require this information in other languages, large print or audio format: 01223216032 or patient informationeaddenbrookes.nhs. uk

Informacje te można otrzymać $w$ innych językach, w wersji dużym drukiem lub audio. Zamówienia prosimy składac pod numerem: 01223216032 lub wysyiając e-mail: patientinformationgeddentrockes.nhs ulk

Polish

Se precisar desta informaçăo num outro idioma, em impressăo

de letras grandes ou formato ádio por favor telefone para o 01223

216032 ou envie uma mensagem para:

patient, informationimaddenbrookes.nhs. ub

Portuguese

Если вам требуется эта информация на другом языке, крупным

шрифтом или в аудиоформате, пожалуйста, обращайтесь по телефону

01223216032 или на вебсайт gatient. informationeliaddenbrogkes. nhs. uk Russian

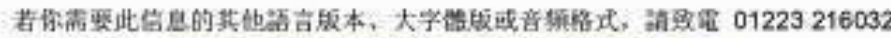

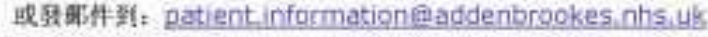

Cantonese

Bu bilgiyi diger dillerde veya büyük baskill ya da sesli formatta

isterseniz latfen su numaradan kontak kurun: 01223216032

veya asagidaki adrese e-posta gonderin:

patient informationeaddenbrookes,ahs, uk

Turkish

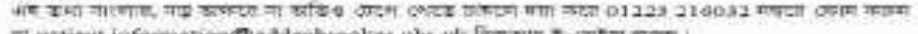

Bengali

Addenbrooke's is smoke-free. Please do not smoke anywhere on the site. For advice on quitting, contact your GP or the NHS smoking helpline free, 08001690169

\begin{tabular}{|c|c|c|c|}
\hline \multicolumn{4}{|c|}{ Document history } \\
\hline Authors & \multicolumn{3}{|l|}{ Sonia sleatenhorst } \\
\hline Department & Children's Services & Contact no & 01223348223 \\
\hline Published & & Review date & \\
\hline File name & \multicolumn{3}{|c|}{ 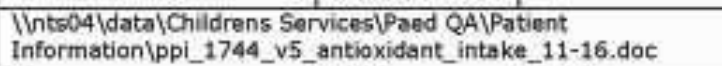 } \\
\hline Version number & 5 & Ref & 1743 \\
\hline
\end{tabular}

\section{Antioxidant intake in paediatric oncology patients}

Participant information sheet for children 11-16 years of age 
You are being invited to take part in a research study. Before you decide it is important for you to understand why the research is being done and how it will affect you. Please read this carefully and talk to others about it if you want.

\section{What question is the study asking?}

The study is trying to find out whether children on cancer treatment are getting enough antioxidants from what they are eating and drinking to meet their needs. The antioxidants we are specially looking at are vitamin A, E, C, zinc and selenium. You may have learnt about these at school or college, Antioxidants help with the repair of cells, tolerating of treatment and decrease treatment delays.

\section{Why have I been invited to take part?}

Each child that is newly diagnosed with cancer will be invited to join this study. By checking each childs diet we will be able to see if you are getting enough of the vitamins and minerals namely vitamin A, E, C, zinc and selenium for good health during treatment. Each child is unique and will contribute with their results to improving the nutrition management given

\section{Do I have to take part in this research study?}

No, it is up to you. If you do your dietitian will ask you to sign a form giving your consent or assent. You will be given a copy of this information sheet and your signed form to keep. You are free to stop taking part at any time during the research without giving a reason. If you decide to stop this will not affect the care you receive.

\section{What will i be asked to do?}

I have asked your parents to keep a food record (diary) for 4 days of everything that you eat and drink. You can help with this if you want to. Your parents will also write down any tube feeds or special drinks you are having.

The dietitian will then look at this food record and work out whether you are getting enough antioxidants in your diet. If you are not getting enough of one or more antioxidants then your

\section{What are the possible benefits of taking part?}

- Your antioxidant (i.e. vitamin A, E, C, selenium and zinc) intake will be checked and compared to the recommended nutrient intake. If there is a deficiency or excess of one or more of the above antioxidants, then your dietitian will advise you on this.

- If the study finds that there is a general trend of low intake of antioxidants during treatment, then a possible supplement could be recommended in future treatment.

- The results obtained would allow us to make recommendations for children that are diagnosed with cancer at a later stage after this study

\section{Will anyone else know I am doing this?}

We will keep your information in confidence. This means we will only tell those who have a need or right to know. Wherever possible we will only send out information that has your name and address removed.

\section{Who has reviewed this study?}

Before any research goes ahead it has to be checked by a Reseach Ethics Committee. They make sure that the research is fair. Your study has ben checked by the Hertfordshire Research Ethics Committee and the Stellenbosch University Ethics Committee.

\section{What if $i$ have any worries?}

If there is anything that you do not understand or which frightens you, do not be afraid to ask mum or dad or the dietitian who is looking after you.

Thank you for taking the time to read this. Please feel free to ask any questions if you need to. 
Paediatric Oncology SDU

\title{
Antioxidant intake in paediatric oncology patients
}

\section{Information sheet for parents/legal guardians}

\section{STUDY NUMBER:}

\author{
NAME OF RESEARCHER: SONJA SLEGTENHORST
}

We would like to invite your child to take part in a research study. Before you decide you need to understand why the reseach is being done and what it would involve for you. Please take time to read the following information carefully. Talk to others about the study if you wish.

Part 1 tells you the purpose of this study and what will happen to you if you take part. Part 2 gives you more detailed information about the conduct of the study.

Please ask us if there is anything that is not clear or if you would like more information. Take time to decide whether or not you wish to take part.

The Committee for Human Research at Stellenbosch University and the Hertfordshire Research Ethics Committee and Addenbrookes Hospital Research and Development Department approved this study. The survey will be conducted according to the ethical guidelines and principles of the international Declaration of Helsinki, South African Guidelines for Good Clinical Practice and the Medical Research Council (MRC) Ethical Guidelines for Research.

\section{PART 1}

\section{What is the purpose of the study?}

The purpose of this research study is to determine whether children diagnosed with cancer are meeting their antioxidant requirements during treatment. The antioxidants measured in the study will be vitamin $A, E, C$, selenium and zinc.

There is widespread interest in the role of antioxidants in the prevention and course of cancer treatment. Studies show the benefits of antioxidants in improving well-being. toleration to treatment and recovery. However further studies show that very large doses of antioxidants can also affect efficacy of certain cancer treatments.

It is important that we determine whether we as health professionals are meeting each child's recommended nutrient intake for antioxidants, therefore giving the best treatment we can.

\section{Why has your child been invited to participate?}

Your child has been chosen to participate in this study, as the data collected will be invaluable/important in the future nutrition management of children undergoing cancer treatment. The greater the number of children recruited for the study, the greater the potential significance of the results and general trends that can be identified. 


\section{Does your child have to take part?}

It is up to you to decide. We will describe the study and go through this information sheet, which we will then give to you. We will then ask you to sign a consent form to show you have agreed to take part. You are free to withdraw at any time, without giving a reason. This would not affect the standard of care you receive.

\section{What will you and your child have to do?}

To determine your child's antioxidant intake you will need to complete $2 \times$ 4-day food records (one which will be issued within the first month after diagnosis and another 3 months later). The primary investigator (Sonja Slegtenhorst) will provide you with the food records and a date to start recording in them. This will enable us to determine your child's antioxidant intake at different periods of the treatment. The week prior to starting the food record the primary investigator will telephone you 4 times (on the Monday, Wednesday, Friday and Sunday) to discuss your child's fluid and food intake over the past 24 hours. These telephone calls will be brief and will serve to validate/reference the food record,

\section{What are the possible disadvantages and risks of taking part?}

This research study is of low risk and there shouldn't be any disadvantages in participating.

\section{What are the possible benefits of taking part?}

Your child will benefit from the study in the following ways:

- Your child's antioxidant (i.e. vitamin A, E, C, selenium and zinc) intake will be analysed and compared to his/her recommended nutrient intake for their age. If your child's diet is deficient in or has an excess of one or more of the above antioxidants, then your dietitian will advise you on how you can adjust this should you wish.

- If the study finds that there is a general trend of low intake of antioxidants, then a plan of action or a guideline can be developed.

- The results obtained would allow us to formulate recommendations for children that are diagnosed later after this study.

\section{What will happen if you decide not to let your child partake in the study?}

If you do not agree to the participation of your child in this study, there will be no repercussions. In other words the decision made to partake or not to partake in this study will not influence the cancer treatment or care provided.

\section{What if there is a problem?}

Any complaint about the way you have been dealt with during the study or any possible harm you might suffer will be addressed. The detailed information on this is in part 2.

\section{Will my taking part in the study be kept confidential?}

Yes. We will follow ethical and legal practice and all information about you will be handled in confidence. The details are included in part 2.

Please note anonymous data will be sent abroad (South Africa) for data analysis by the statistician.

If the information in part 1 has interested you and you are considering participation please read the additional information in part 2 before making any decision. 


\section{PART 2}

\section{What will happen if I don't want to carry on with the study?}

If you do consent initially and decide to change your mind during the study the data already collected cannot be deleted from the database and will still be processed.

\section{What if there is a problem? \\ Complaints}

If you have a concem about any aspect of this study you should ask to speak to the researcher who will do her best to answer your questions (Sonja Slegtenhorst 01223 216655). If you remain unhappy and wish to complain formally you can do this through the NHS Complaints Procedure. Details can be obtained from the hospital.

\section{Harm}

In the event that something does go wrong and your child is harmed during the research and this is due to somones negligence than you may have grounds fro a legal action for compensation against Addenbrooke's Hospital but you may have to pay your legal costs. The normal NHS complaints mechanisms will still be available to you.

\section{Will my taking part in this study be kept confidential?}

All information that is collected about your child during the course of the research will be kept strictly confidential and any information about your child that leaves the hospital will have his/her name and address removed so that they cannot be recognised.

\section{What will happen to the results of the research study?}

The results of this research study may be published in a medical journal once the study is completed. The results may be presented at the Paediatric Oncology Interest Group (members of British Dietetic Association) or at a conference. The child would not be identified in any publication. Two Supervisors in the field of Dietetics as well as a Paediatric Oncology Consultant will regularly review the data collected from this study.

\section{Who has reviewed the study?}

All research in the NHS is looked at by an independent group of people called a Research Ethics Committee to protect your safety, rights, well-being and dignity. This study has been reviewed and given favourable opinion by the Hertfordshire Research Ethics Committee and the University of Stellenbosch Research Ethics Committee.

\section{Will you or your child be paid to take part in this study and are there any costs involved?}

You and your child will not be paid to take part in the study. There will be no costs involved for the parent/carer.

\section{Further information and contact details}

If you have any concerns or other questions about the study or the way it has been carried out, you should contact the Chief Investigator (Sonja Slegtenhorst, Nutrition and Dietetic 
Department, Addenbrookes Hospital, Cambridge CB2 2QQ, tel 01223216655 ) or you may contact the Hospital Patient Advice and Liaison Service on 01223 216756/257

\section{Many thanks for taking the time to read this information leaflet.}

Please ask if you require this information in other languages, large print or audio format: 01223216032 or patient. informationialaddenbrookes.nhs.uk

Informacje te można otrzymać $w$ innych językach, $w$ wersji dużym drukiem lub audio. Zamówienia prosimy składać pod numerem: 01223216032 lub wysylając e-mail: patient.information@addenbrookes,nhs,uk

Polish

Se precisar desta informaçăo num outro idioma, em impressão

de letras grandes ou formato áudio por favor telefone para o 01223216032 ou envie uma mensagem para: patient,informationsaddenbrookes,nhs, uk

Portuguese

Если вам требуется эта информация на другом языке, крупным шрифтом или в аудиоформате, пожалуйста, обращайтесь по телефону 01223216032 или на вебсайт patient.information@addenbrookes.nhs.uk

Russian

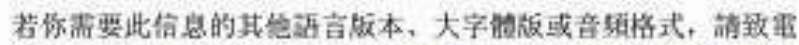

01223

216032

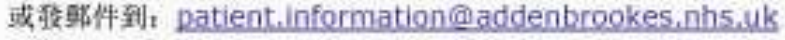

\section{Cantonese}

Bu bilgiyl diger dillerde veya buyuak baskilı ya da sesli formatta isterseniz lütfen su numaradan kontak kurun: 01223216032

veya asagıdaki adrese e-posta gönderin: patient, information @addenbrookes.nhs,uk

Turkish

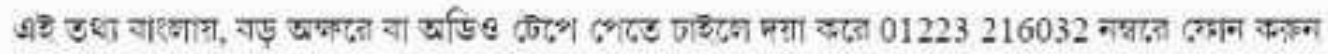

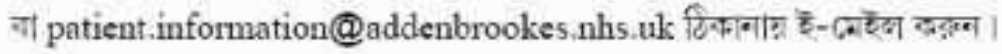

\section{Bengali}

Addenbrooke's is smoke-free. Please do not smoke anywhere on the site.

For advice on quitting, contact your GP or the NHS smoking helpline free, 08001690 169

\begin{tabular}{|c|c|}
\hline \multicolumn{2}{|c|}{ Document history } \\
\hline Authors & Sonja Slegtenhorst \\
\hline Department & $\begin{array}{l}\text { Addenbrooke's Hospital, Cambridge University Hospitals NHS } \\
\text { Foundation Trust, Hills Road, Cambridge, CB2 OQQ } \\
\text { www,addenbrookes,org.uk }\end{array}$ \\
\hline Contact number & 01223348223 \\
\hline \multicolumn{2}{|l|}{ Published } \\
\hline \multicolumn{2}{|l|}{ Review date } \\
\hline File name & 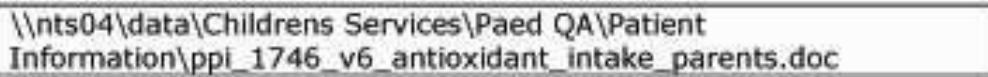 \\
\hline Version number & 6 \\
\hline Ref & 1746 \\
\hline
\end{tabular}




\title{
Paediatric Oncology SDU
}

\section{Antioxidant intake in paediatric patients with solid tumours and lymphomas Information sheet for general practitioners}

\author{
Your patient \\ is being invited to enter a research study and \\ this information sheet aims to explain the study in which your patient has been \\ asked to participate.
}

\section{What is the purpose of the study?}

The reason for this research study is to determine whether children diagnosed with cancer are meeting their antioxidant requirements during treatment. The antioxidants are vitamin $A, E, C$, selenium and zinc.

There is widespread interest in the role of antioxidants in the prevention and course of cancer treatment. Studies show the benefits of antioxidants in decreasing free radicals, improving well-being, toleration to treatment and recovery. However contrary to this further studies show that mega-doses of antioxidants can also affect efficacy of certain cancer treatments. It is therefore important that we determine whether we as health professionals are ensuring that children during treatment are meeting their RNI (recommended nutrient intakes) for antioxidants. Parents frequently query the use of vitamin and mineral supplementation during treatment especially antioxidant intake.

Upon diagnosis, the dietitian or Consultant will approach each newly diagnosed cancer patient to take part in this study. The dietitian will discuss the study and the requirements in a short interview. The only requirement of the participant is the accurate completion of a 4-day food record. Tube/sip feeds; other food supplements and vitamin-mineral supplements will need to be written down. A food portion size booklet will be provided to help with the accurate completion of the food record. The participant will be provided with a pre-paid envelope to return the food record.

The results from the study will be sent to each participant in the study. If upon analysis of the food record it showed that a participant was deficient or in excess of the requirement for an antioxidant then he/she will be informed. The dietitian will provide appropriate advice with regard to this.

\section{Does my patient have to participate?}

If your patient or his/her parents, decide that they don't want to enter the study this is entirely up to them and it will not affect their medical care. 


\section{Will my patients taking part in this study be kept confidential?}

All data collected will be confidential and used specifically for this study. Your child's identifiable information will be omitted from study related material to ensure confidentiality, Upon entering the study each child will receive a subject identification number, which will be used on all study related material and documentation.

All verbal conversations and written information collected will be kept confidential. Should the study be used in a publication or thesis, the identity of the children will remain anonymous.

\section{Who is organising the research?}

The research is being organised by a qualified Paediatric Dieititian; Sonja Slegtenhorst, based at the Nutrition and Dietetic Department at Addenbrookes Hospital. If you have any have any specific questions about the study contact the chief researcher, Sonja Slegtenhorst. Nutrition and Dietetic Department, Addenbrookes Hospital. Tel 01223 216655

Many thanks for taking the time to read this information leaflet. 
Please ask if you require this information in other languages, large print or audio format: 01223216032 or patient,information(a)addenbrookes.nhs.uk

Informacje te można otrzymać $w$ innych językach, $w$ wersji dużym drukiem lub audio. Zamówienia prosimy składać pod numerem: 01223216032 lub wysyłając e-mail: patient.information@addenbrookes.nhs.uk

Polish

Se precisar desta informação num outro idioma, em impressão de letras grandes ou formato áudio por favor telefone para o 01223216032 ou envie uma mensagem para: patient.information@addenbrookes.nhs.uk Portuguese

Если вам требуется эта информация на другом языке, крупным шрифтом или в аудиоформате, пожалуйста, обращайтесь по телефону 01223216032 или на вебсайт patient.information@addenbrookes.nhs.uk

\section{Russian}

若你需要比信息的其他語言版本、大字踖版或音頻格式, 請致霆 01223216032 或發俄件到: patient,information@addenbrookes,nhs,uk

\section{Cantonese}

Bu bilgiyi diger dillerde veya būyük baskilı ya da sesli formatta isterseniz lütfen su numaradan kontak kurun: 01223216032 veya asagıdaki adrese e-posta gönderin: patient.information (a) addenbrookes.nhs. uk Turkish

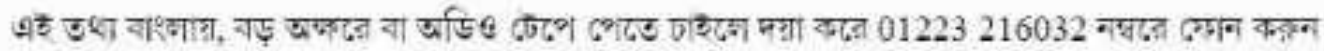

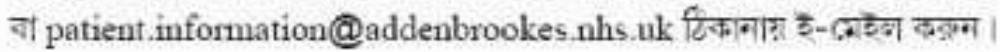

\section{Bengali}

Addenbrooke's is smoke-free. Please do not smoke anywhere on the site. For advice on quitting, contact your GP or the NHS smoking helpline free, 08001690169

\begin{tabular}{|c|c|}
\hline \multicolumn{2}{|c|}{ Document history } \\
\hline Authors & Sonja Slegtenhorst \\
\hline Department & $\begin{array}{l}\text { Addenbrooke's Hospital, Cambridge University Hospitals NHS } \\
\text { Foundation Trust, Hills Road, Cambridge, CB2 OQQ } \\
\text { www addenbrookes,org.uk }\end{array}$ \\
\hline Contact number & 01223348223 \\
\hline Published & 25.03 .08 \\
\hline Review date & Apr-12 \\
\hline Flle name & 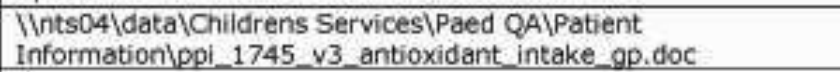 \\
\hline Version number & 3 \\
\hline Ref & 1745 \\
\hline
\end{tabular}




\section{Parental agreement to study participation}

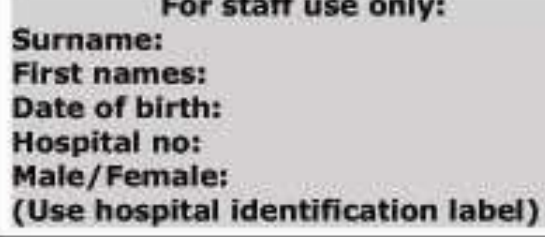

Responsible health professional/job title

Special requirements

(eg other language/other communication method)

\section{Name of proposed procedure or course of treatment}

Title of study: Antioxidant intake in paediatric oncology patients.

Centre number:

Study number:

Name of researcher: Sonja Slegtenhorst Pt identification no for this study:

\section{Statement of health professional}

I have explained the study to the child and his/her parent(s). In particular, I have explained:

- How it will be carried out

- The intended benefits of the study

- Any serious or frequently occurring risks including those specific to the patient

I have discussed what the study is likely to involve and any particular concerns of this patient and his/her parent(s).

- The following information leaflet has been provided:

Version/Date/Ref:

Health professional's signature

Date:

Name (PRINT):

Job title:

Contact details (if patient/parent wishes to discuss details later)

I have offered the parent information about the study but s/he has declined information.

Important notes: (tick if applicable)

- The parent has withdrawn consent (ask parent to sign/date here)

\section{Statement of the interpreter (if appropriate)}

I have interpreted the information to the child and his/her parent(s) to the best of my ability, and in a way in which I believe they can understand:

Interpreter's signature Date:

Name (PRINT):

\section{Copy accepted by parent: yes / no (please circle)}




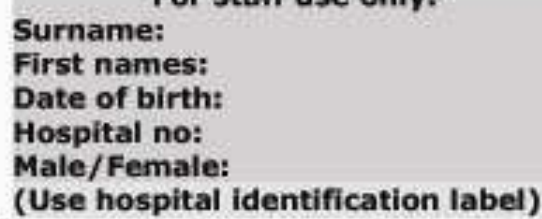

Statement of parent

Please read this form carefully. You will be offered a copy of this consent form. Do ask if you have any further questions. The staff at Addenbrooke's are here to help you. You have the right to change your mind at any time before the study is undertaken, including after you have signed this form. Training doctors and other health professionals is essential to the continuation of the Health Service and improving the quality of care. Your child's treatment may provide an important opportunity to improve the nutritional management for such training.

$\mathbf{I}$ agree to my child's participation in the study described on this form and $\mathbf{I}$ confirm that I have 'parental responsibility' for this child.

The risks, and benefits of this study have been discussed with me.

I understand that all research will be approved by a research ethics committee and undertaken in accordance with appropriate ethical, legal and professional standards.

I understand that the research may be conducted within a hospital, university, not for profit organisation or a company laboratory.

I have read, or had read to me the information sheet and consent form and that it is written in a language with which I am fluent and comfortable.

My child is older than 7 years, and his her assent is recorded below

I confirm I have had the opportunity to ask questions and all my questions have been adequately answered

I understand that taking part in this study is entirely voluntary

I understand that my child may be asked to leave the study before it has finished if the study doctor or researcher feels it is in my childs best interests, or if my child does not follow the study plan as agreed to

I agree to anonymous data being sent abroad to a statistician in South Africa for data analysis.

I have been told about additional measures that will be taken should the dietary information suggest correction of a deficiency, I have listed below any procedures that I do not wish, without further discussion, to be carried out.

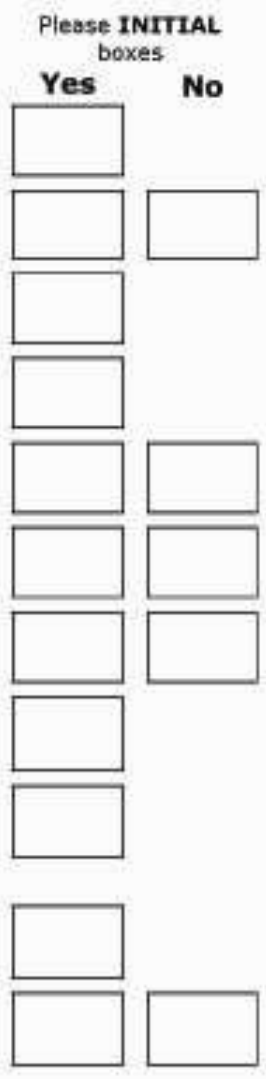

Parent's signature:

Date:

Name (PRINT): Relationship to child:

Child's agreement to treatment (if child wishes to sign):

I agree to have the study I have been told about.

Signature:

Date:

Name (PRINT)

Cambridge University Hospitais NHS Foundation Trust

Page 2 of 2

Comparison of Antioxidant Intake Study - Consent Form (CSOFRM162 v5)

Published: Jun-09 


\begin{tabular}{|l|c|}
\hline $\begin{array}{l}\text { Children's Services } \\
\text { Paediatric Oncology and Haematology }\end{array}$ & $\begin{array}{c}\text { Addenbrooke's Hospital WTHS } \\
\text { Combridge University Hospitals NHS Foundation Trust }\end{array}$ \\
\hline Reasearch Study - Food Record \\
\hline
\end{tabular}

\section{Checklist}

Have you written down:

All the foods eaten, including sweets and nibbles?

$0 \quad$ All drinks including water, squash, fizzy drinks, fruit juice and tea/coffee (on average how much / day)

- Multivitamin-mineral preparations (brand, amount and posted packaging/information leaflet)?

0 Tube/sip or other food supplements used? (amount, hours over which pump ran, time/feed set up and stopped, preparation if powder feed)

- Fruit, vegetables, smoothies, fruit juice, dried fruit?

- Types of protein sources eaten such as dairy, meat, chicken, fish, seafood, lentils beans etc eaten preparation method and amount?

- Spreads ie type of jam, margarine, butter, Bovril, peanut butter

- Have you clearly stated how the food was prepared? Eg: battered fried fish, grilled premium sausage, mashed potato with butter, etc

$\checkmark \quad$ Did your child eat very differently when you kept this food record? Please specify if certain days different eg 'Tuesday: persistent vomiting after chemotherapy'

\begin{tabular}{|l|c|}
\hline $\begin{array}{l}\text { Children's Services } \\
\text { Paediatric Oncology and Haematology }\end{array}$ & $\begin{array}{c}\text { Addenbrooke's Hospital NFS } \\
\text { Cambridge University Hosoitel sNHS Foundation Trust }\end{array}$ \\
\hline
\end{tabular}

\section{Research Study - Food Record}

- We would like you to write down everything that your child has had to eat and drink each day (including sip/tube feeds and other supplements)

- If your child is using a tube/sip feed, please write down the exact amount of feed given. Exact amounts can be taken from your pumps memory. Please docu-

The exact volume

Rate $(\mathrm{ml} / \mathrm{hr})$

Time feeds were given, ie $9 \mathrm{pm}-7 \mathrm{am}$

- Use the food portion size booklet and shapes with measurements at the end of this book to help you to give accurate portion sizes

- Please give as much DETAIL as you can about each item, e.g. fried egg, raw carrot, mashed potato with butter

- Describe how MUCH of each food and drink you have e.g. give the number of cups of tea or coffee, type and slices of bread, fish fingers, biscuits, sweets etc

- The AMOUNT of foods or fluids taken can be described by household measures g. tablespoon (e.g. puddings, vegetables) or teaspoons (e.g. sugar, jam) or measuring cups (e.g. mik, tea) or ma, Chbox size (e.g. cheee)

- If there are any LEFTOVERS, e.g. skin from apple, bone from chop, please say so - REMEMBER to include:

* Cups of tea, coffee, drinking chocolate (say if sugar or milk added) or squash Cups of tea, coffee, drinking chocolate (say if sugar
(say if sugar free and on average how much/day)

* $\quad$ Between meal snacks

* Sweets, chocolates

* $\quad$ Fruit

* Crisps, nuts, other savoury snacks

Please include / send any food/drink labels that may be useful for the analysis 


\begin{tabular}{|l|c|}
\hline $\begin{array}{l}\text { Children's Services } \\
\text { Paediatric Oncology and Haematology }\end{array}$ & $\begin{array}{c}\text { Addenbrooke's Hospital WiTS } \\
\text { Cambridge University Hospitals NHS Foundation Trust }\end{array}$ \\
\hline Reasearch Study - Food Record \\
\hline
\end{tabular}

\section{Example of a days meals:}

\begin{tabular}{|c|c|c|}
\hline Meal/time of day & Food item & Amount eaten \\
\hline Breakfast & $\begin{array}{l}\text { Weetabix } \\
\text { Full cream milk } \\
\text { Hovis thick slice brown bread } \\
\text { Tsp apricot jam } \\
\text { Tsp flora lite } \\
\text { 100ml Ribena }\end{array}$ & $\begin{array}{l}1 \\
1 \text { teacup } \\
1 / 2 \\
2 \\
2 \\
100 \mathrm{ml}\end{array}$ \\
\hline Lunch & $\begin{array}{l}\text { Raw cherry tomatoes } \\
\text { White pitta bread (small) } \\
\text { Tuna in brine } \\
\text { Mayonaise (normal) }\end{array}$ & $\begin{array}{l}3 \text { small } \\
1 / 2 \\
1 / 2 \text { tin }(60 \mathrm{~g}) \\
2 \text { tablespoons }\end{array}$ \\
\hline 3pm snack & $\begin{array}{l}\text { Apple raw (large) } \\
\text { Cadbury cream egg }\end{array}$ & $\begin{array}{l}1, \text { core not eaten } \\
1 / 2\end{array}$ \\
\hline Dinner & $\begin{array}{l}\text { Mashed potato with } \\
\text { butter } \\
\text { Peas, boiled in water with salt } \\
\text { Fish Fingers - Birds Eye } \\
\text { Tomato sauce - Heinz }\end{array}$ & $\begin{array}{l}3 \text { heaped tablespoons } \\
1 \text { teaspoon } \\
4 \text { heaped tablespoons } \\
2 \\
2 \text { teaspoons }\end{array}$ \\
\hline & 5 tall glasses of Ribena & $\geq 1000 \mathrm{mls}$ \\
\hline \multicolumn{3}{|c|}{ Tube, sip feed or other supplements given } \\
\hline \multicolumn{3}{|l|}{$1 \times$ calcichew tablet } \\
\hline \multicolumn{3}{|c|}{$300 \mathrm{ml}$ Nutrini energy at $30 \mathrm{~m} / \mathrm{hr} \times 10 \mathrm{hrs}(9 \mathrm{pm}-7 \mathrm{am})$} \\
\hline \multicolumn{3}{|l|}{ or } \\
\hline \multicolumn{3}{|c|}{$\begin{array}{l}\text { Neocate Advance: Preparation method } 1 \text { sachet }+340 \mathrm{ml} \text {. Given } 750 \mathrm{ml} \text { of feed } 9 \mathrm{pm}-7 \mathrm{am} \text { at } 75 \mathrm{~m} / \mathrm{hr} \times \\
10 \mathrm{hrs}\end{array}$} \\
\hline
\end{tabular}

Cambridge University Hospitals NHS Foundation Trust

Resaerch Study - Food Record (CSOFRM161 v 4)

\begin{tabular}{|l|c|}
\hline $\begin{array}{l}\text { Children's Services } \\
\text { Paediatric Oncology and Haematology }\end{array}$ & $\begin{array}{c}\text { Addenbrooke's Hospital W/HS } \\
\text { Cambridge University Hospitals NHS Foundation Trust }\end{array}$ \\
\hline Research Study - Food Record \\
\hline
\end{tabular}

Research Study - Food Record

\section{Extra sheet - Date}

\begin{tabular}{|l|l|l|}
\hline Meal/time of day & Food item & \\
\hline & & \\
& & \\
& & \\
& & \\
\hline Tube, sip feed or other supplement eaten \\
\hline \\
\end{tabular}

Cambridge University Hospitals NHS Foundation Trust

Resaerch Study - Food Record (CSOFRM161 v4)

Published: June-09 


\begin{tabular}{|l|c|}
\hline $\begin{array}{l}\text { Children's Services } \\
\text { Paediatric Oncology and Haematology }\end{array}$ & $\begin{array}{c}\text { Addenbrooke's Hospital WRS } \\
\text { Cambridge University Hospitals NHS Foundation Trust }\end{array}$ \\
\hline Reasearch Study - Food Record \\
\hline
\end{tabular}

\section{Saturday - Date}

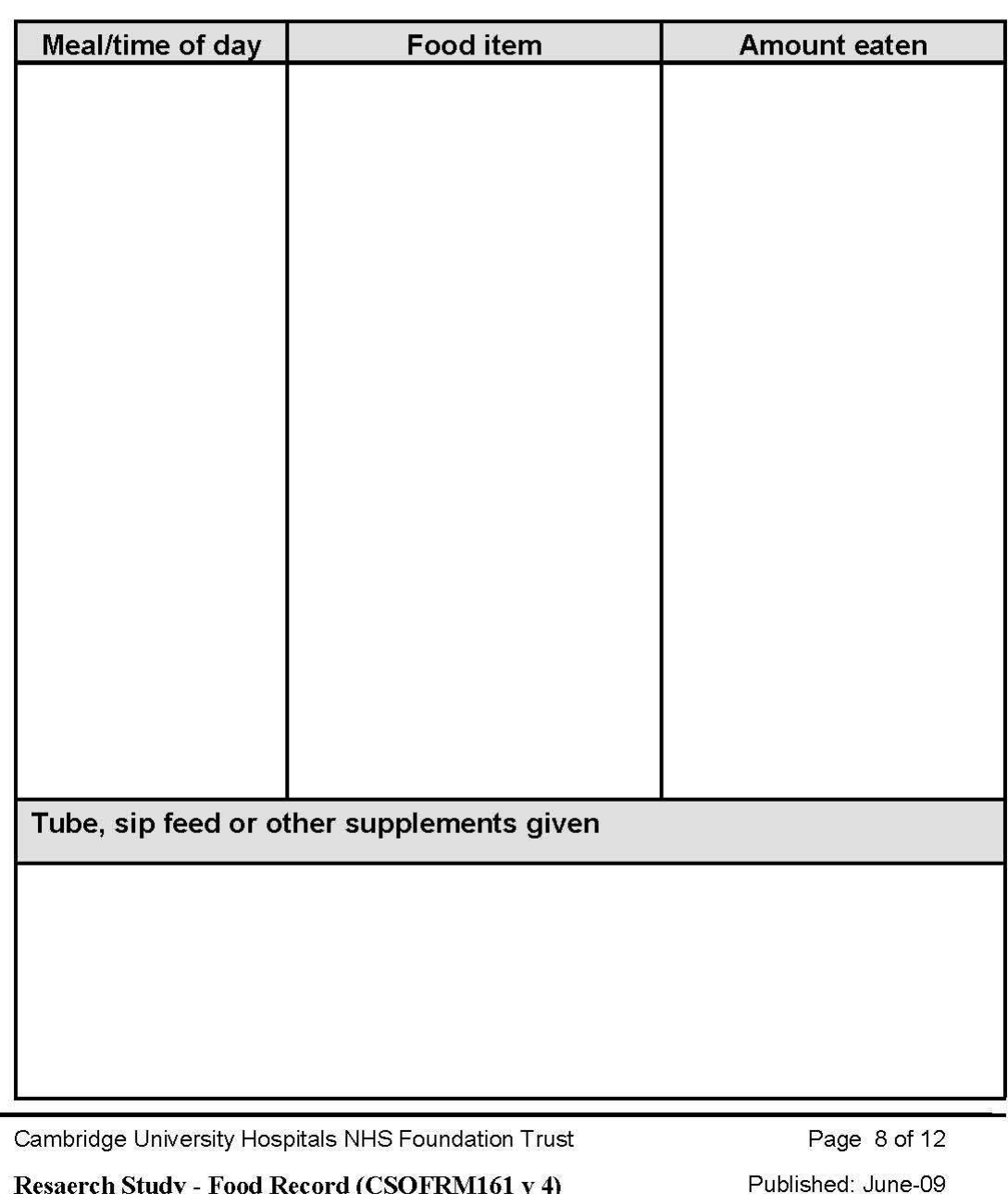

\begin{tabular}{|l|c|}
\hline $\begin{array}{l}\text { Children's Services } \\
\text { Paediatric Oncology and Haematology }\end{array}$ & $\begin{array}{c}\text { Addenbrooke's Hospital W/HS } \\
\text { Cambridge University Hospitals NHS Foundation Trust }\end{array}$ \\
\hline Research Study - Food Record \\
\hline
\end{tabular}

\section{Wednesday - Date}

\begin{tabular}{|l|l|l|}
\hline Meal/time of day & Food item & Amount eaten \\
\hline & & \\
& & \\
& & \\
\hline Cambridge University Hospitals NHS Foundation Trust & \\
\hline & & \\
\hline Tube, sip feed or other supplements given & \\
\hline
\end{tabular}




\begin{tabular}{|l|c|}
\hline $\begin{array}{l}\text { Children's Services } \\
\text { Paediatric Oncology and Haematology }\end{array}$ & $\begin{array}{c}\text { Addenbrooke's Hospital WHS } \\
\text { Cambridge University Hospitals NHS Foundation Trust }\end{array}$ \\
\hline Reasearch Study - Food Record \\
\hline
\end{tabular}

\begin{tabular}{|l|c|}
\hline $\begin{array}{l}\text { Children's Services } \\
\text { Paediatric Oncology and Haematology }\end{array}$ & $\begin{array}{c}\text { Addenbrooke's Hospital W/HS } \\
\text { Cambridge University Hospitals NHS Founcation Trust }\end{array}$ \\
\hline Research Study - Food Record \\
\hline
\end{tabular}
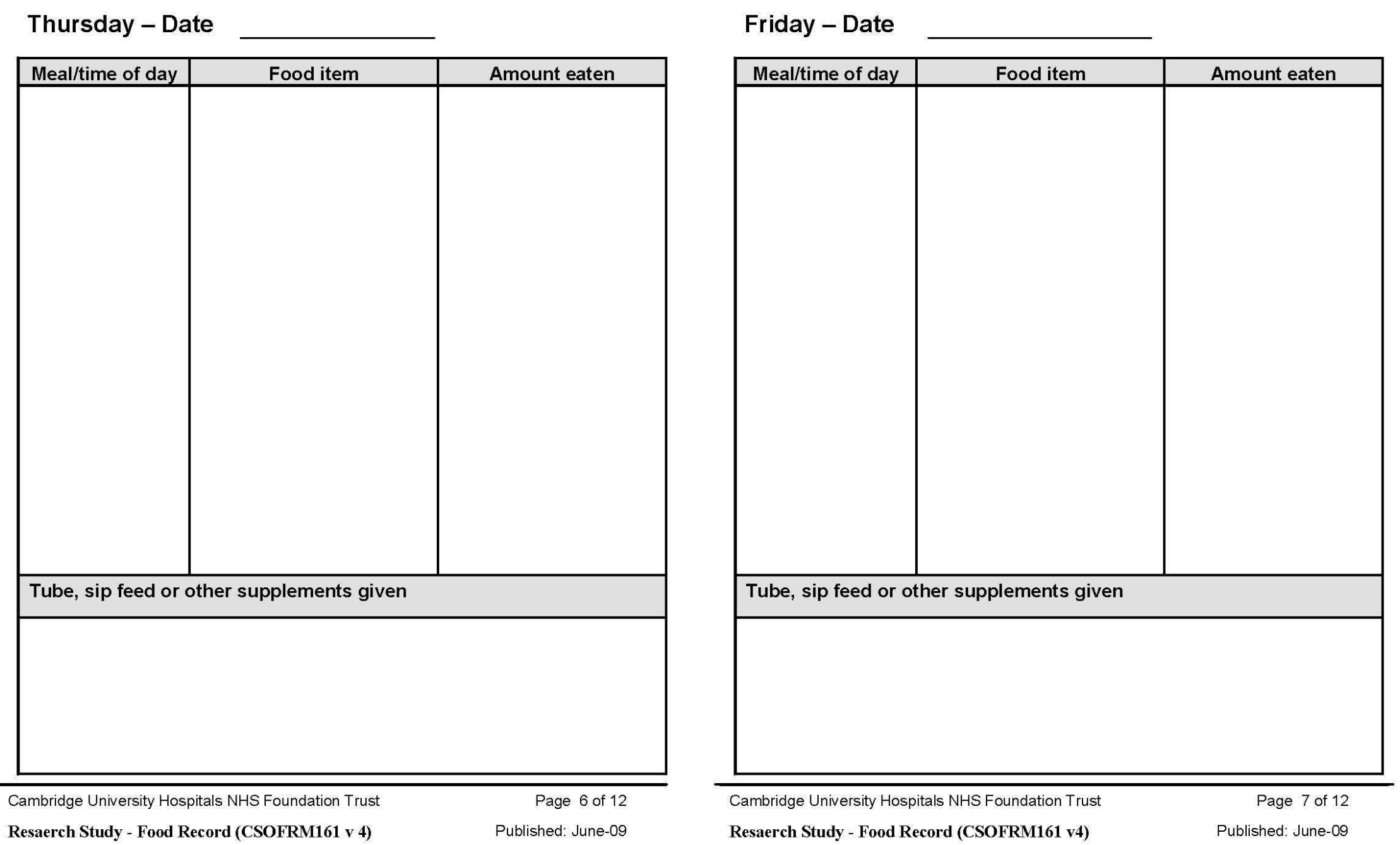


\section{ADDENDUM I: 24 Hour recall}

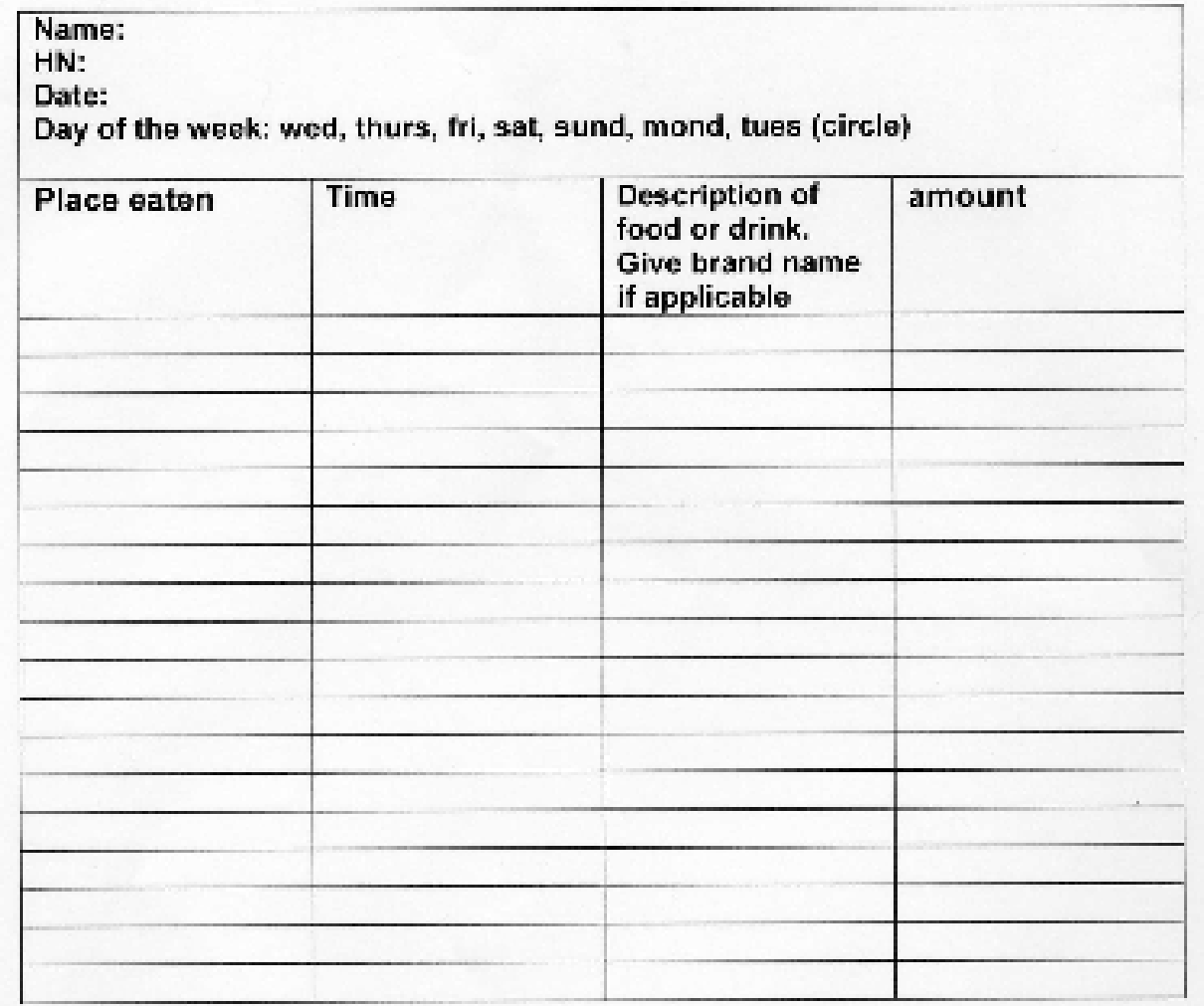

Additional questions

Was intake unusual in any way? Yesi / Noi )

If yes in what way?

Do you take vitaminiminaral or antioxidant supplements? Yes ( ) No ( )

If yes, how many per day? ( ) per week? ( )

If yes, what kind? ịive brand if possible?

Multivitarnin Iron Ascorbic acid

Other (list;

Are you on any tube feeds? Yos: j No (;

If yes, what kind?

If yes, how much each day? 
ADDENDUM J: Nutritional Support Algorithm (Addenbrookes Hospital)

Children's Services

Addenbrooke's Hospital

Paediatric Oncology and Haematology

\section{Clinical Procedure}

\section{Nutritional Intervention for Paediatric Oncology Patients}

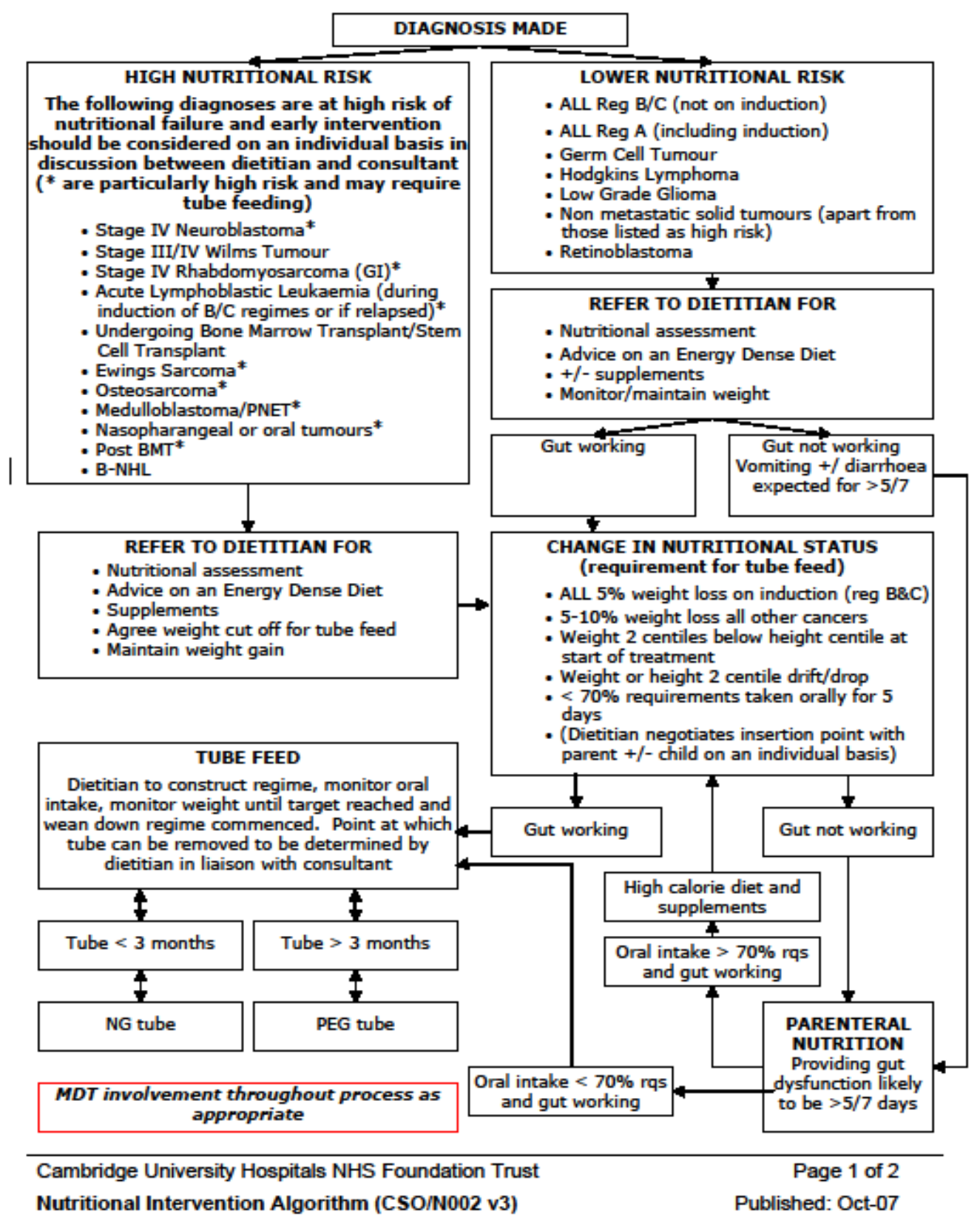


ADDENDUM K: Critique forms

Critiqued by Vanessa Shaw (Head of Dietetic Department, Great Ormond Street Hospital) and Anita MacDonald (Head of Dietetics at Birmingham Children's Hospital)

Question

Yes No

Comments

Does the EFR meet the following requirements:

a. Clearly indicate number of days to be completed

b. Elicits information on the type, dose, and frequency of vitamin/mineral supplements?

\begin{tabular}{|l|l|l} 
& $\sqrt{ }$ & \\
& & \\
$\sqrt{ }$ & $\sqrt{ }$ &
\end{tabular}

I think the first page is very busy. I think it should say it is a 4 day record and then put brackets that are 3 week days and 1 weekend day. I think it would be better to specify the days

In your protocol you say that you want the EFR completed on consecutive days ie Wed, Thu, Fri, Sat. If you want intake for these specific days recorded you should indicate this on the front page. I think it would be better to put:

- Any vitamin \& mineral supplements? Yes

- What is the name

- How much do you give each day

- Do you give it every single day

- Comments

c. Clearly states that any relevant vitamis and/or mineral supplement packaging should be returned with the EFR?

d. Clearly indicates the address to where the EFR and vitamin and/or mineral packaging should be returned.

General contents:

a. Is it clear how to document:

b. - portion sizes

c. Leftovers

d. Amounts

e. Preparation, amount and type of tube feed and/or vitamin and/or mineral supplements

Note is unclear - needs rewording

No need for the *Note. Just add preparation information leaflet to the next instruction line

(

- Maybe not a good idea to give rashes of bacon as an example of food as unacceptable to Muslim families. Would have been a good idea to include a double check for types of common foods used it the diet, e.g. type of milk, spread used e.g. butter, margarine, low fat spread, type of squash/cold drink(how many drinks per day on average). This would have provided useful information. Need to ask children to state brand of food even save food labels.

- pump's memory

- Time feeds were given - do you mean eg, rather than ie?

- You need to define cup. This could be interpreted as a teacup, a mug or an American cup (as used in recipes). 


\begin{tabular}{|c|c|c|c|}
\hline & & & $\begin{array}{l}\text { - Need to ask which type of milk is used in tea etc. How many } \\
\text { teasp of sugar, drinking chocolate? } \\
\text { - Day's meals } \\
\text { - How much Ribena/squash in the drink? } \\
\text { - Give } 2 \text { pages for each day - not much room for people who } \\
\text { have big and untidy handwriting }\end{array}$ \\
\hline $\begin{array}{l}\text { Checklist page } \\
\text { Does the checklist help the parent/guardian to } \\
\text { recall items that may have been missed whilst } \\
\text { documenting in the EFR? }\end{array}$ & $\sqrt{ }$ & & $\begin{array}{l}\text { Why mention protein as a food group? You haven't included other food } \\
\text { groups. Will all families know what you mean by dairy? Eaten appears } \\
\text { twice in this sentence. } \\
\text { Spreads eg not ie } \\
\text { - Why do you have blank pages }-2,11,12\end{array}$ \\
\hline Is the EFR user friendly? & $\sqrt{ }$ & $\sqrt{ }$ & $\begin{array}{l}\text { Too crowded. A lot of detail but not spread out enough. } \\
\text { But give more examples on page } 4 \text {. Did you mean there to be no milk } \\
\text { added to the Weetabix? Is sugar added? Say how much Ribena is in } \\
\text { the } 100 \mathrm{ml} \text { drink. Give an example of tea plus milk plus sugar. Give an } \\
\text { example of a sandwich so that they can see that they need to record } \\
\text { how many slices of bread, butter added, filling added - you don't want } \\
\text { an entry just to read ' } 1 \text { cheese sandwich'. }\end{array}$ \\
\hline $\begin{array}{l}\text { Does the EFR elicit information pertaining to the } \\
\text { studies objectives? }\end{array}$ & $\sqrt{ }$ & & $\begin{array}{l}\text { Yes, but a food frequency diary may have yielded additional information } \\
\text { about antioxidant status. } \\
\text { But intake of food and drink needs to be more accurately recorded } \\
\text { than you have indicated. }\end{array}$ \\
\hline $\begin{array}{l}\text { Use in other studies } \\
\text { Is the EFR reproducible in other similar studies? }\end{array}$ & $\sqrt{ }$ & & With the above modifications. \\
\hline
\end{tabular}


Addendum L Approval letter for Human Research Committee of Stellenbosch University (South Africa)

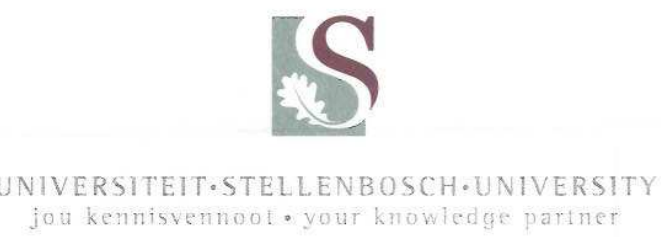

23 June 2008

Ms S Slegtenhorst

Division of Human Nutrition

Dept of Interdisciplinary Health Sciences

Dear Ms Slegtenhorst

\section{RESEARCH PROJECT : : "ANTIOXIDANT INTAKE IN PAEDIATRIC PATIENTS WITH SOLID TUMOURS AND LYMPHOMAS" \\ PROJECT NUMBER : N08/04/094}

My letter dated 22 April 2008 refers.

At a meeting that was held on 11 June 2008, the Committee for Human Research ratified the approval of the above project by the Chairperson.

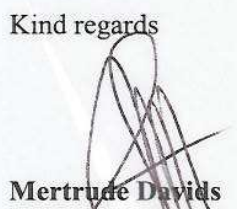

RESE/ARCHWEVELOPMENT AND SUPPORT (TYGERBERG)

Tel: +27219389207/E-mail: mertrude@sun.ac.za 
Addendum M Approval letter from the Hertfordshire Research Ethics Committee (England), R \& D Department (Addenbrookes Hospital) and Sponsorship letter

\section{Hertfordshire REC}

East of England REC Office No 3 9th Floor, Terminus House

The High

Harlow

Essex

CM20 1XA

Tel: 01279418439

Fax: 01279419246

07 April 2009

Dr Rosan M Meyer

Specialist Paediatric Dietitian

Imperial College School of Medicine

St.Mary's Hospital Campus

Room 252, Norfolk Place

London

W2 1BG

Dear Dr Meyer

Study title:

REC reference:

Amendment number:

Amendment date:
Antioxidant intake in Paediatric Oncology Patients with Solid Tumours and Lymphomas $08 / \mathrm{H} 0311 / 53$

2

03 January 2009

The above amendment was reviewed at the meeting of the Sub-Committee of the REC held on 03 April 2009.

\section{Ethical opinion}

The members of the Committee present gave a favourable ethical opinion of the amendment on the basis described in the notice of amendment form and supporting documentation.

\section{Approved documents}

The documents reviewed and approved at the meeting were:

\begin{tabular}{|l|l|l|}
\hline Document & Version & Date \\
\hline Protocol & 3 & 03 January 2009 \\
\hline Notice of Substantial Amendment (non-CTIMPs) & 2 & 03 January 2009 \\
\hline
\end{tabular}

Membership of the Committee

The members of the Committee who took part in the review are listed on the attached sheet.

$R \& D$ approval 
All investigators and research collaborators in the NHS should notify the R\&D office for the relevant NHS care organisation of this amendment and check whether it affects R\&D approval of the research.

\section{Statement of compliance}

The Committee is constituted in accordance with the Governance Arrangements for Research Ethics Committees (July 2001) and complies fully with the Standard Operating Procedures for Research Ethics Committees in the UK.

\section{8/H0311/53:}

\section{Please quote this number on all correspondence}

Yours sincerely

Mrs Jenny Austin

Committee Co-ordinator

E-mail: jenny.austin@eoe.nhs.uk

Enclosures

List of names and professions of members who took part in the review

Copy to:

Sonja Slegtenhorst

Specialist Paediatric Dietician

Addenbrookes Hospital

Hills Road

Cambridge

CB2 OQQ

Dr John Bradley

Box 277

Cambridge University Hospital NHS Foundation Trust

Addenbrookes Hospital

Hills Road

Cambridge

Hertfordshire REC

CB2 OQQ

Attendance at Sub-Committee of the REC meeting on 03 April 2009

\begin{tabular}{|l|l|l|}
\hline Name & Profession & Capacity \\
\hline Dr Steve Eckersall & Consultant Anaesthetist & Expert \\
\hline Mrs Vivien Felgate & Senior Pharmacist & Expert \\
\hline Dr Sunda Uthayakumar & Consultant Physician HIV \& GUM & None \\
\hline
\end{tabular}




\section{Addenbrooke's Hospital W/RS}

Cambridge University Hospitals NHS Foundation Trust

Research and Development Department

Box 277

Addenbrooke's Hospital Hills Road

RSD ref: $A 091289$

Cambridge

CB2 $0 Q Q$

03 September 2008

Direct Diai: $01223384468+58468$

Miss Sonja Slegtenhorst

Switchboard: 01223245151

Nutrition and Dietetic Department.

Box 119.

E-mail: Harnnt.Sehgaipaddenbtopkes.nhs us

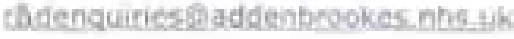

wwo caddenbrocksos, org uk

Dear Miss Slegtenhorst

\section{Re: 08/H0311/53 Antioxidant intake in Paediatric Oncology Patients with Solid Tumours and Lymphomas}

Thank you for sending details of the above named REC study. I understand that this has been approved by Hertfordshire REC under the 'exempt from Site Specific Assessment' guidelines and as such does not require local ethical approval.

RSO have reviewed this project and $t$ am pleased to inform you that we are approving the work to proceed within Cambridge University Hospitals NHS Foundation Trust.

Sponsor: Imperial College London,

Funder: Own Account.

End date: 01/05/2009

Protocol: version 1 dated 31/03/2008

The project must follow the agreed protocol and be conducted in accordance with all Trust Policies and Procedures especially those relating to research and cata management.

Please ensure that you are aware of your responsibilities in relation to The Data Protection Act 1998. NHS Confidentiality Code of Practice, NHS Caidicott Report and Caldicott Guardians, the Human Tissue Act 2004, Good Clinical Practice, the NHS Reseatch Governance Framework for Health and Social Care, Second Edition April 2005 and any further legislation released during the time of this study.

Members of the research team must have appropriate substantive or honorary contracts with the Trust prior to the study commencing. Any additional researchers who join the study at a later stage must also hoid a suitable contract.

\section{Amendments}

Please ensure that you submit a copy of any amendments made to this study to the R8D Department and that any changes are not implemented untif both ethical and R\&O approval has been received. 


\section{Annual Report}

It is obligatory that you submit a yearly annual report to the research ethics committee and that you send a copy to the R8D Department. The yearly period commences from the date of receiving a favourable opinion from the ethics committee.

Please refer to our website www.addenbroakes org. uk/research/research index.html for all information relating to R\&D including honorary contract forms, policies and procedures and data protection.

Should you require any further information please do not hesitate to contact us.

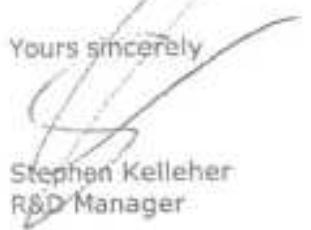


Stellenbosch University http://scholar.sun.ac.za

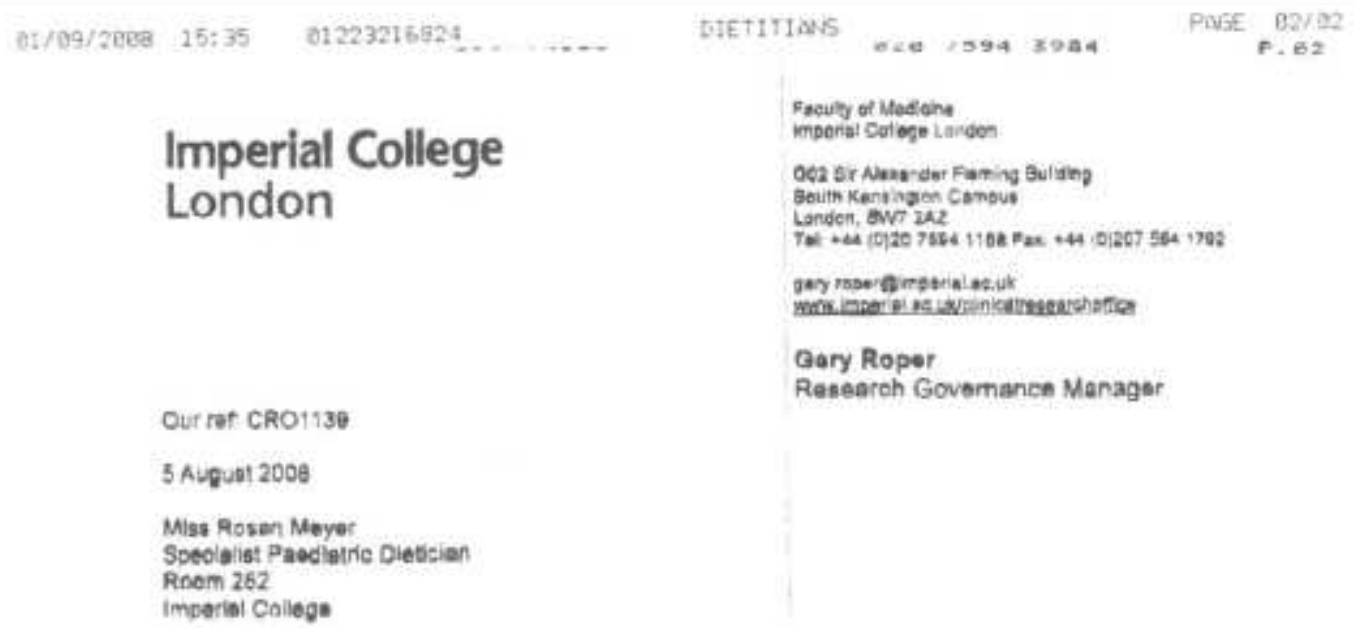




\section{Dear Niss Meyer}

Ro: Antiexident intake in pasdiatric oneology petienta with solid tumours and lymphomas

This in is confim that the above named ratearch shoject utises human perticipanta, their organs. Hasue and/or date ae dofined uncer the spenserehip requirements of the Resesarch Ouvamance Frantwork for Haakh and Social Care 2005 . Incorpornting the Medieines for Human Use (Cilnical Trals) Regulations 2004.

On berar of imperiai Collegs of Solonce. Technology and Medicina, we undertave to act as the identhed Resaarch Sponsor for this prolect.

This iefter confirme

- The reesarch proposai has been discissec, assessed and regigtered with imperiai Collape Cliricel Research Offico and proviaibnal apensot approval grantea

- The Chisd investigstor has undergone a process of scientirc critieve commansurate with the scale of the project

- Ineemnity and insuranoe artangements have bean put in place to eover the orojoct

- Rasourcet and eugport are avalatle to the resesmeh team to aid delivery of the receareh an propased.

- Manegomant, monitoning and roporting respons oifies for the tassarch have been asproved.

- Imperiai College wil undartake and enlorce those aponoor duties sol aut in the Nirs Research Governence Framewock for Health and Social Care

Imperin| Colloge Sponeorehip is conditlonal on the project reselving appliceblo ethical and

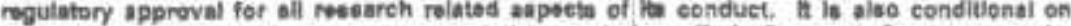
eucesasful contract and agresment negotiations and aigh off via Rosearch Bervicet and the Contracting Offles, where relevsent, and before the study commences.

A copj of the athics approva inter muet be sent to the Research Governance Manoger prof to the

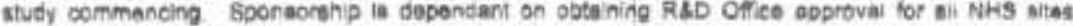
where the rasesten is being conduoted

Yours sincere?

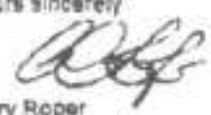

Gery Roper

Rescoroh Governance Marage:

Faculty of Medicine

inperial College Landon 
Addendum N Comparison of Antioxidant Intakes to the Dietary Reference Values and Safe Intakes $\left(1^{\mathrm{ST}}\right.$ and $3^{\text {rd }}$ month)

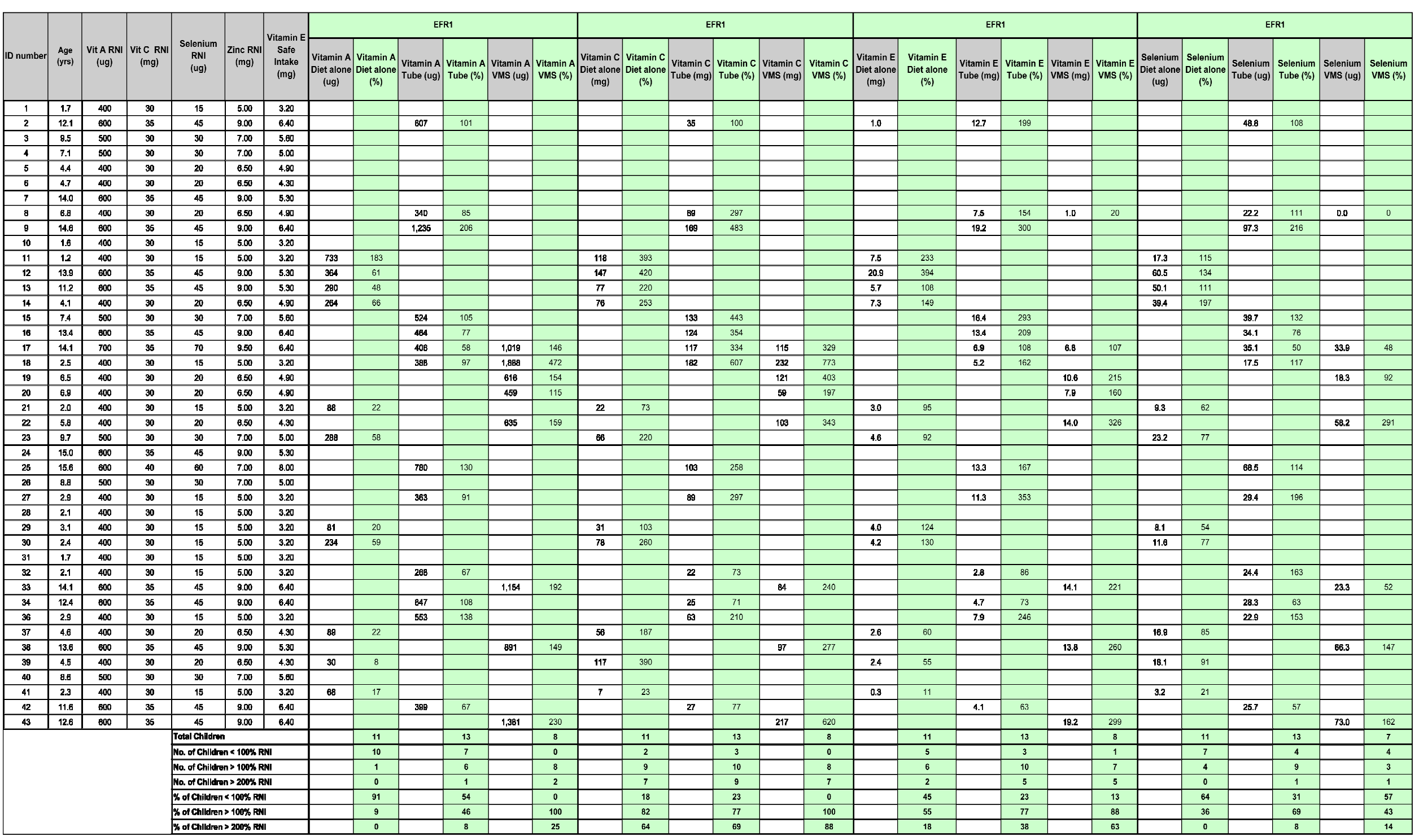




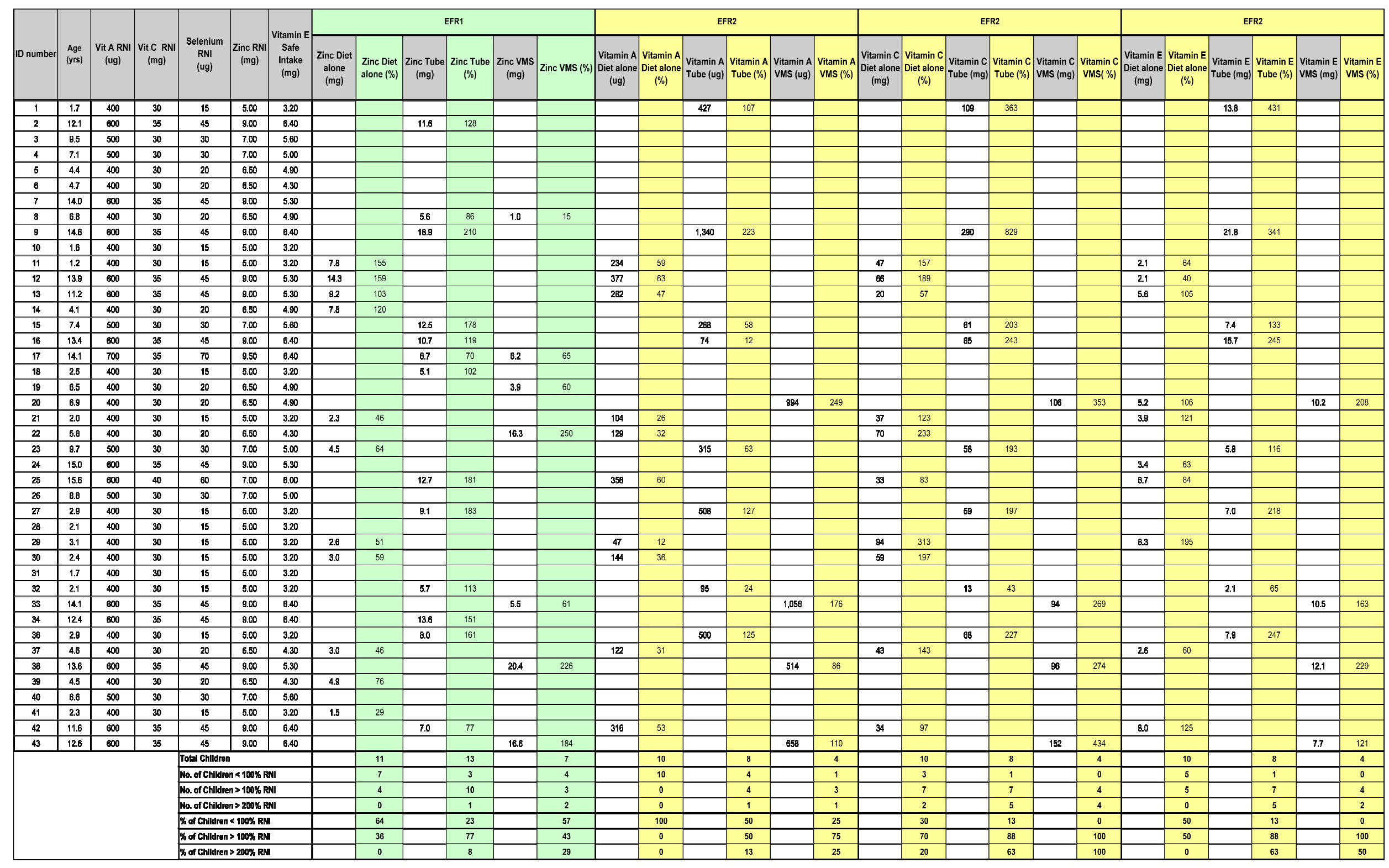




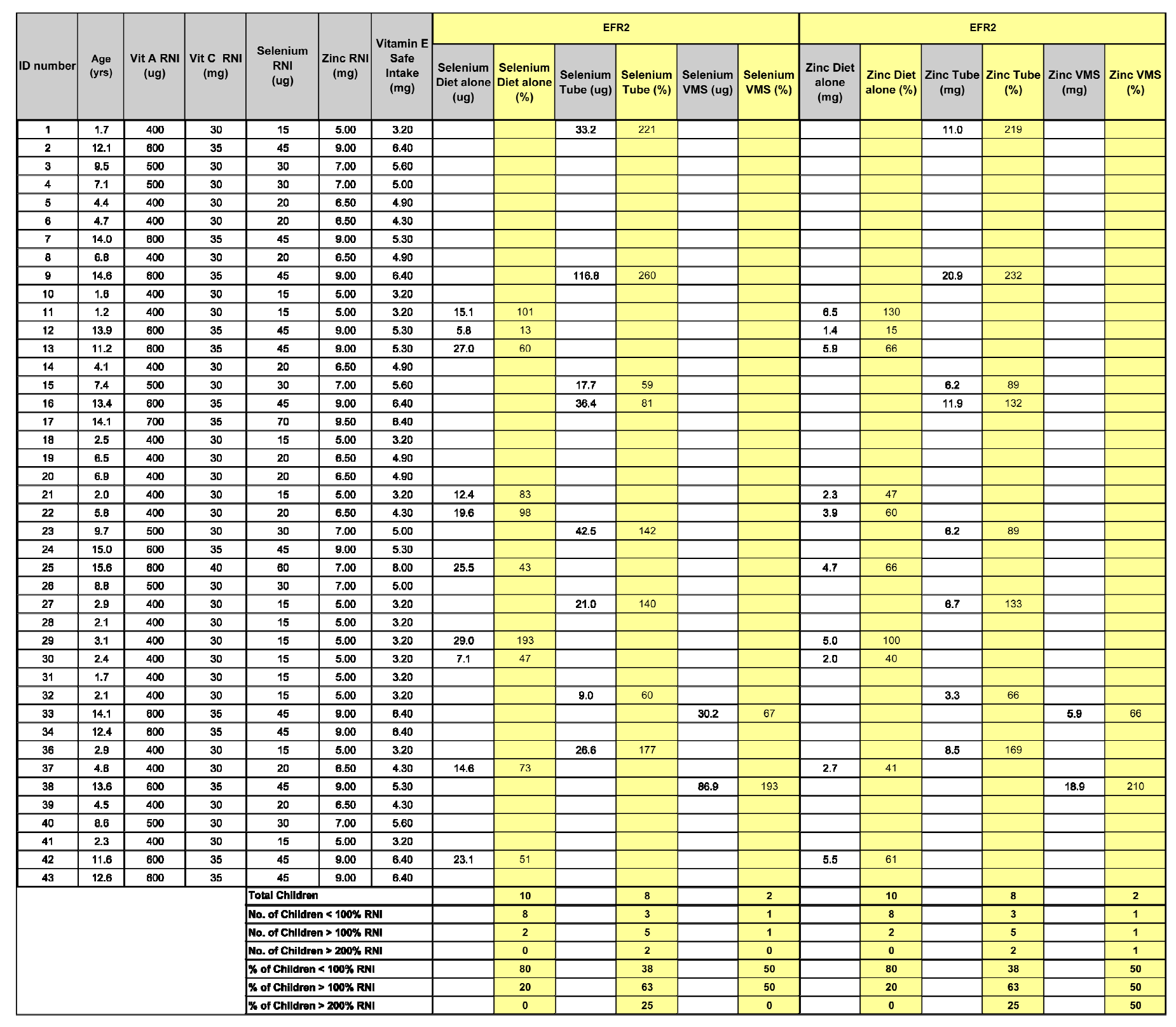


Addendum $\mathrm{O}$ Comparison of Antioxidant Intakes to the Lower Recommended Nutrient Intakes ( $1^{\text {st }}$ and $3^{\text {rd }}$ month)

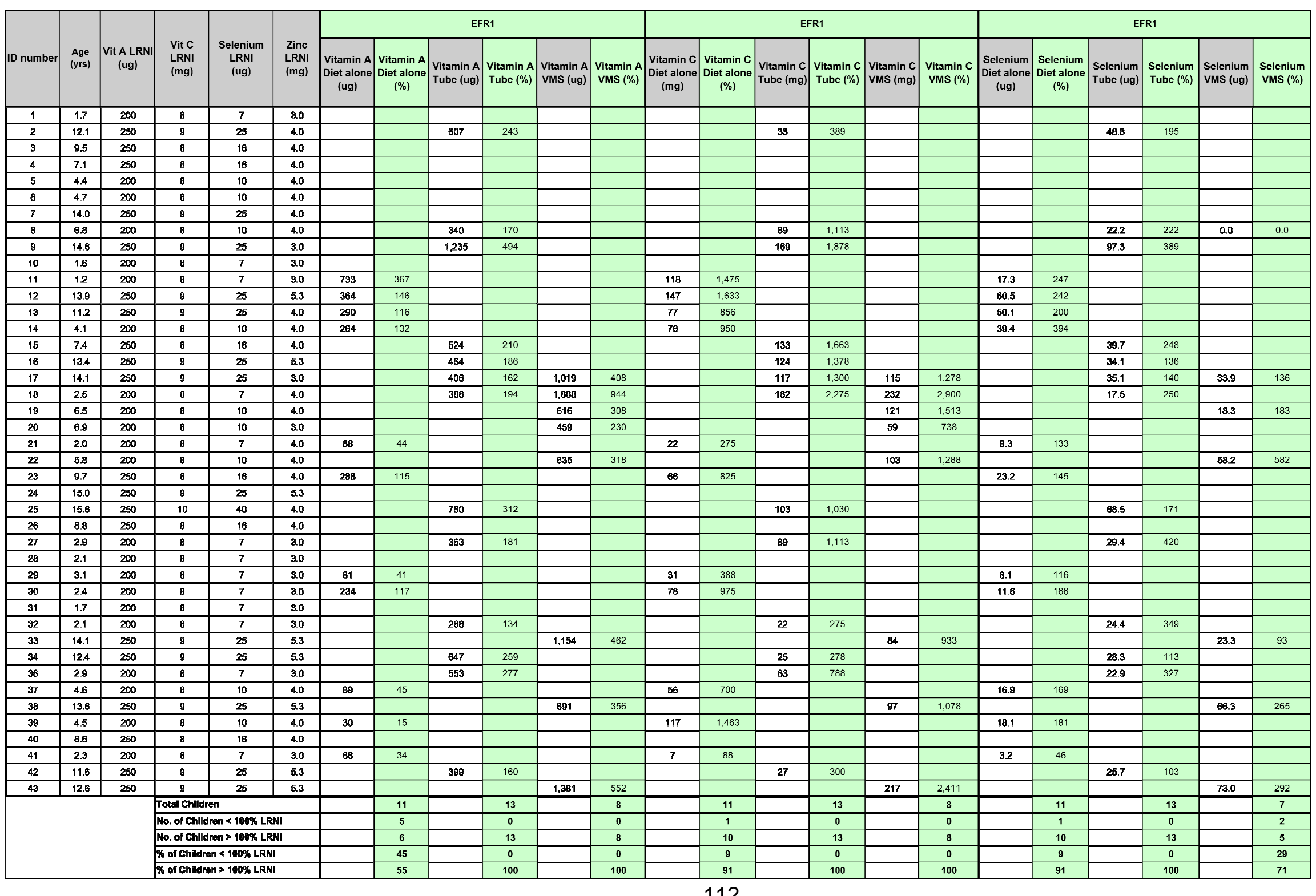




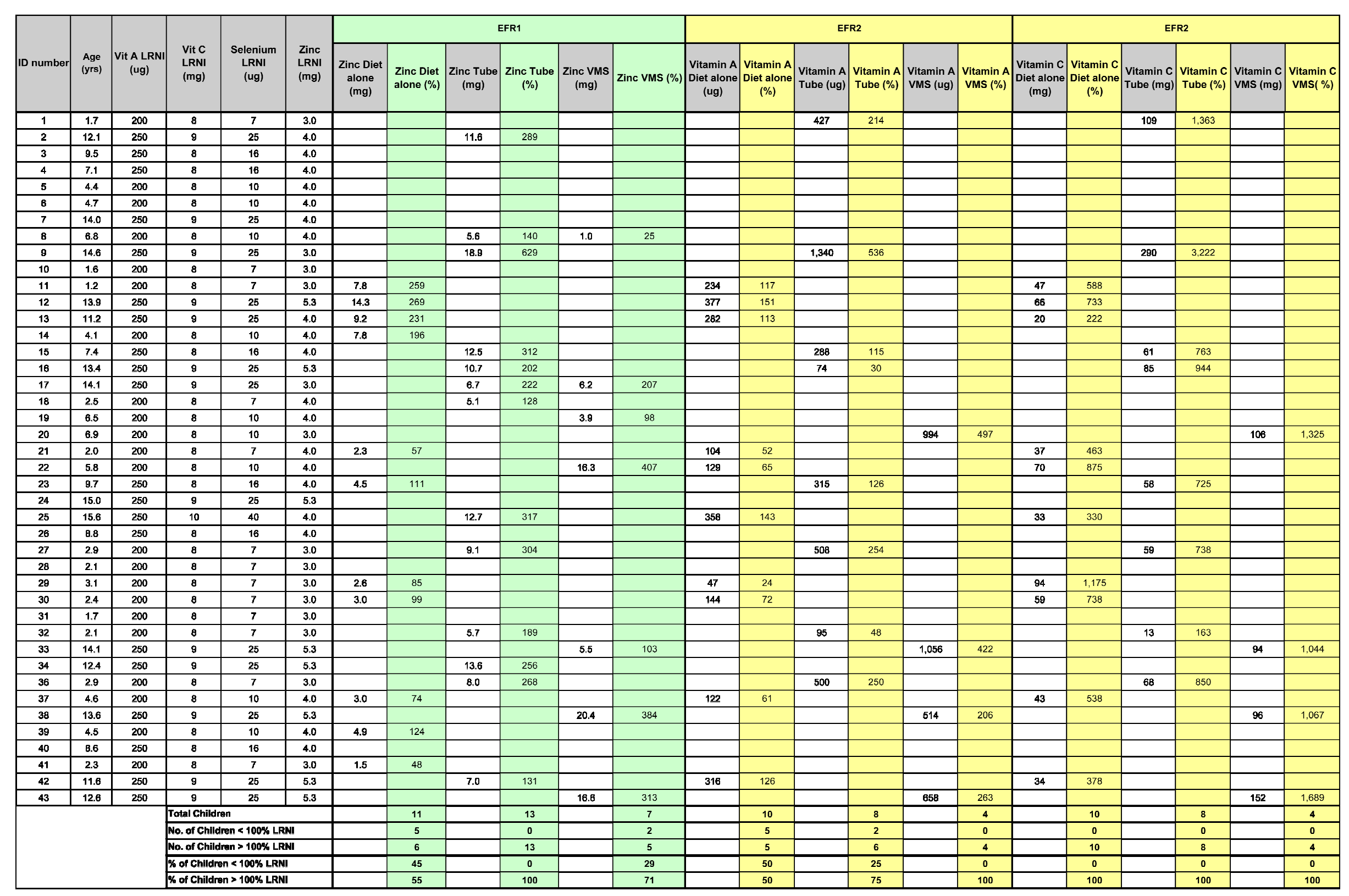




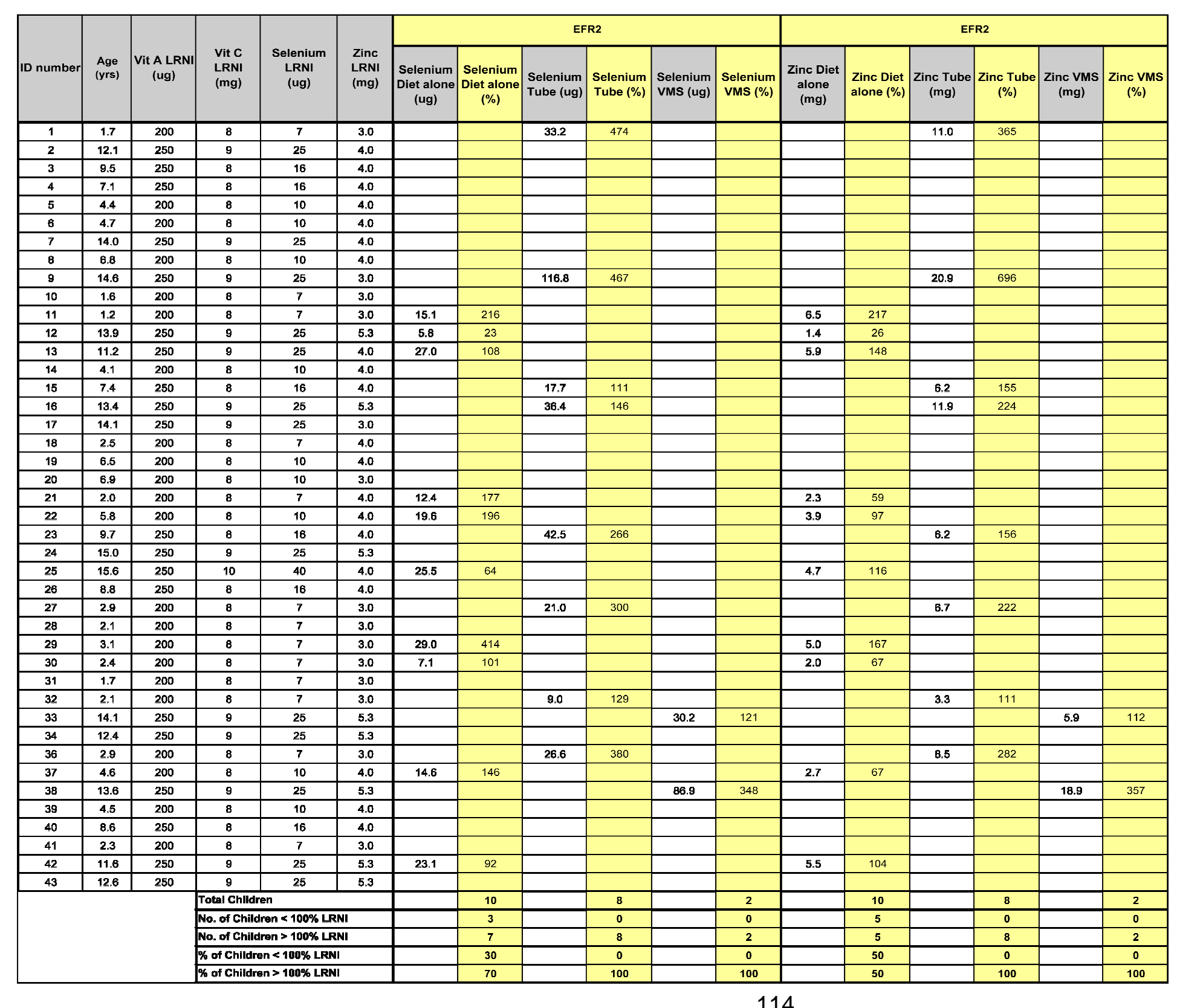


Addendum P Comparison of Energy and Protein to the Estimated Average Requirements ( $1^{\text {st }}$ and $3^{\text {rd }}$ month)

\begin{tabular}{|c|c|c|c|c|c|c|c|c|c|c|c|c|c|c|c|c|c|c|c|}
\hline \multirow[b]{2}{*}{$\begin{array}{c}\text { ID } \\
\text { Mumber }\end{array}$} & \multirow[b]{2}{*}{$\begin{array}{l}\text { Apo } \\
\text { Qures) }\end{array}$} & \multirow[b]{2}{*}{$\begin{array}{l}\text { Eoeryy } \\
\text { intaks } \\
\text { EAs } \\
\text { theal }\end{array}$} & \multirow[b]{2}{*}{$\begin{array}{l}\text { Protein } \\
\text { intake } \\
\text { EAR ial }\end{array}$} & \multicolumn{8}{|c|}{ EFA } & \multicolumn{8}{|c|}{ EPAC } \\
\hline & & & & $\begin{array}{l}\text { Calorias } \\
\text { Diet } \\
\text { abne } \\
\text { Ohesil }\end{array}$ & $\begin{array}{c}\text { Calaries } \\
\text { Oivet } \\
\text { Alone } \\
\text { (Wa) }\end{array}$ & $\begin{array}{l}\text { Calaries } \\
\text { Tube } \\
\text { placait }\end{array}$ & $\begin{array}{l}\text { Calories } \\
\text { Tube Nove }\end{array}$ & \begin{tabular}{|c|} 
Protains \\
Dist \\
Alone \\
Aheat
\end{tabular} & $\begin{array}{l}\text { Protains } \\
\text { Dsot } \\
\text { Alone } \\
\text { (N) }\end{array}$ & $\begin{array}{c}\text { Proleins } \\
\text { Tube } \\
\text { proal }\end{array}$ & $\begin{array}{l}\text { Proteins } \\
\text { Tube CSL }\end{array}$ & $\begin{array}{l}\text { Calories } \\
\text { Diet Alose } \\
\text { thoal }\end{array}$ & $\begin{array}{c}\text { Caboliks } \\
\text { Oint Adoes } \\
\text { (W) }\end{array}$ & $\begin{array}{c}\text { Calonies } \\
\text { Tubs } \\
\text { Okcoll }\end{array}$ & \begin{tabular}{|l|} 
Caliorien \\
Tube $\left(\mathrm{N}_{1}\right.$
\end{tabular} & $\begin{array}{c}\text { Probeins } \\
\text { Dist Nonse } \\
\text { proseff }\end{array}$ & $\begin{array}{l}\text { Proteins } \\
\text { Diet Mone } \\
\text { (N) }\end{array}$ & $\begin{array}{l}\text { Protuies } \\
\text { Toted } \\
\text { (thead }\end{array}$ & $\begin{array}{l}\text { Broluens } \\
\text { Tuto (X) }\end{array}$ \\
\hline$T$ & 15 & 120 & 72 & & & 100 & 파 & & & $\sqrt{63}$ & 540 & & & Wh17 & कू & & & कर & 28 \\
\hline 2 & 121 & 2200 & 34 & & & 1,055 & 4II & & & 34 & 101 & & & & & & & & \\
\hline 3 & 85 & 1900 & 3 & & & & & & & & & & & & & & & & \\
\hline 4 & 71 & 1740 & 23 & & & & & & & & & & & & & & & & \\
\hline 5 & 44 & 1716 & 15 & & & & & & & & & & & & & & & & \\
\hline है & 47 & 1715 & $\frac{15}{15}$ & & & & & & & & & & & & & & & & \\
\hline 7 & 140 & 1.845 & 35 & & & & & & & & & & & & & & & & \\
\hline 5 & 618 & 1715 & 15 & & & 1,206 & 7 & & & 37 & 3a & & & & & & & & \\
\hline 9 & 14.6 & 2200 & मू & & & 3028 & 137 & & & है। & 20 & & & 3013 & 136 & & & प्रत & क्या \\
\hline 10 & 16 & 1.18 & 12 & & & & & & & & & & & & & & & & \\
\hline 11 & 12 & 1.08 & 12 & 1,3 & 10 & & & 36 & 303 & & & 39 & $\pi$ & & & 3 & 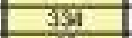 & & \\
\hline 12 & 131 & 1815 & 38 & 2.066 & 792 & & & 116 & 251 & & & ब्य & 13 & & & in & का & & \\
\hline$\frac{13}{13}$ & 112 & 1845 & 35 & 1.00 & 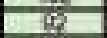 & & & 78 & 2015 & & & 101 & का & & & 5 & तथd & & \\
\hline$\frac{11}{11}$ & 41 & 1715 & 15 & 1.and & 116 & & & 65 & 988 & & & & & & & & & & \\
\hline 15 & 74 & 190 & 23 & & & 786 & 5 & & & 41 & $7 m$ & & & 1002 & 2 & & & 26 & 78 \\
\hline$\frac{16}{16}$ & 137 & $2 \pi$ & 15 & & & 153 & हां & & & 20 & 61 & & & 2720 & 70 & & & 35 & 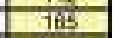 \\
\hline 17 & 10.1 & 220 & 35 & & & 2182 & 8 & & & 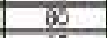 & 24 & & & & & & & 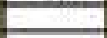 & \\
\hline 18 & 25 & 1.165 & 12 & & & 7,332 & th & & & 22 & 950 & & & & & & & & \\
\hline 19 & 65 & 1.715 & 15 & & & & & & & & & & & & & & & & \\
\hline 20 & 39 & 7715 & 15 & & & & & & & & & & & & & & & & \\
\hline 21 & 20 & 1.96 & 12 & 820 & 35 & & & 18 & 155 & & & 1006 & 86 & & & 35 & 260 & & \\
\hline 2 & 58 & 1345 & 35 & & & & & & & & & 975 & 50 & & & 87 & 252 & & \\
\hline 2 & $\frac{7}{53}$ & 1.740 & 23 & 1,280 & $\%$ & & & 42 & 213 & & & 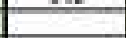 & 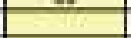 & 1,802 & क & & & GA & 201 \\
\hline 24 & 1650 & 1846 & 33 & & & & & & & & & & & & & & & & \\
\hline 25 & 16.6 & 275 & 48 & & & 2002 & 73 & & & 60 & $17 \mathrm{~A}$ & 1.208 & 48 & & & 28 & 90 & & \\
\hline 29 & 80 & 1.740 & 23 & & & & & & & & & & & & & & & & \\
\hline 27 & 20 & $\frac{1.156}{1.56}$ & 12 & & & 1,80 & TH & & & 35 & 28 & & & 1.134 & ज्ञ & & & 15 & 302 \\
\hline $2 \pi$ & 21 & 1.150 & 12 & & & & & & & & & & & & & & & 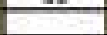 & \\
\hline 2 & 3.1 & 1.185 & 12 & 900 & 78 & & & 26 & 220 & & & 1254 & 7103 & & & 41 & 351 & & \\
\hline 32 & 24 & 1.165 & 12 & 722 & 62 & & & 23 & 197 & & & $5 B 5$ & $B 0$ & & & 10 & 165 & & \\
\hline 31 & 13 & 1.106 & 12 & & & & & & & & & & & & & & & & \\
\hline 32 & 21 & 1.186 & 12 & & & 1.200 & 106 & & & $\angle 2$ & 357 & & & 290 & 42 & & & 16 & 135 \\
\hline 33 & 14.1 & 2220 & 34 & & & & & & & & & & & & & & & & \\
\hline 3 & 12.4 & 22200 & 34 & & & 3,265 & 147 & & & 123 & 384 & & & & & & & & \\
\hline 30 & 20 & 1230 & 12 & & & 1.500 & 128 & & & $\frac{47}{47}$ & 466 & & & 1.345 & 109 & & & 61 & 435 \\
\hline 37 & 4.6 & 1.545 & 15 & \begin{tabular}{|l}
1,006 \\
\end{tabular} & 85 & & & 36 & 235 & & & 691 & $4 !$ & & & 28 & $\sqrt{178}$ & & \\
\hline 38 & 13.6 & 1.846 & 33 & & & & & & & & & & & & & & & & \\
\hline 39 & 4.5 & 1.546 & 15 & 1,037 & 67 & & & 40 & 268 & & & & & & & & & & \\
\hline 40 & 8.5 & 1.570 & 23 & & & & & & & & & & & & & & & & \\
\hline 41 & 23 & 1.230 & 12 & 330 & 27 & & & $\pi$ & 55 & & & & & & & & & & \\
\hline 42 & 11.6 & 22200 & 34 & & & 985 & 45 & & & 45 & 153 & 1.326 & का & & & 4 & 189 & & \\
\hline 43 & 12.6 & 22200 & 34 & & & & & & & & & & & & & & & & \\
\hline \multicolumn{4}{|c|}{ Total chatern 12.0} & & II & & 14 & & $\pi 1$ & & 14 & & 50 & & \pm & & 10 & & $\pi$ \\
\hline \multicolumn{4}{|c|}{ 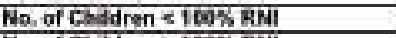 } & & $\frac{10}{t}$ & & $\frac{27}{8}$ & & $\frac{1}{t}$ & & $\frac{19}{6}$ & & 9 & & 5 & & $\frac{7}{2}$ & & 0 \\
\hline \multirow{2}{*}{\multicolumn{4}{|c|}{ 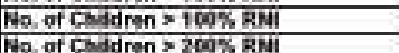 }} & & 7 & & 6 & & 10 & & 14 & & $i$ & & 3 & & it & & in \\
\hline & & & & & 6 & & 8 & & 7 & & 9 & & 0 & & 9 & & 4 & & 5 \\
\hline \multicolumn{4}{|c|}{ 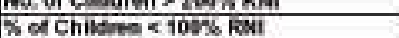 } & & 73 & & 57 & & 9 & & 6 & & 00 & & है & & 20 & & 0 \\
\hline \multicolumn{4}{|c|}{ 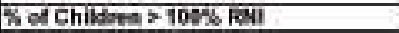 } & & 87 & & 85 & & क1 & & 100 & & 10 & & 遇 & & 0 & & 100 \\
\hline \multicolumn{4}{|c|}{ 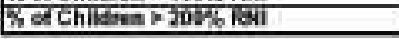 } & & 6 & & 0 & & 73 & & 64 & & 0 & & $\overline{0}$ & & 45 & & ह5 \\
\hline
\end{tabular}


